https://doi.org/10.5817/RPT2021-2-6

\title{
VYBRANÉ ASPEKTY PRÁVA NA SPRAVODLIVÝ PROCES A AUTOMATIZÁCIA ROZHODOVANIA ${ }^{1}$
}

\author{
ANDREJ KRIŠTOFÍK ${ }^{2}$
}

\begin{abstract}
ABSTRAKT
$S$ rozvojom technológií môžeme pozorovat’ aj ich prienik to oblasti justície, kedy $v$ súčasnosti zastávajú rôzne pomocné analytické funkcie. Do akej miery môžeme túto pozíciu technológií $v$ súdnej sieni rozširovat závisí nie len na vývoji technológii ale aj rámca, ktorý nastavuje právo. Pre súdne rozhodovania je rámec akýchkol’vek možných inovácií nastavený primárne právom na spravodlivý proces. Táto práca sa preto zameriava na posúdenie vplyvu automatizácie súdneho rozhodovania na včasnost', či na prístup $k$ súdu. Ďalej práca rozoberá aj nezaujatost’ a nestrannost', spolu s predstavením technických aspektov tohto problému, verejnosti a záverom sa venuje zostatkovým právam, z ktorých je najväčší priestor venovaný právu na odôvodnené rozhodnutie. Tieto aspekty potom spoločne tvoria právo na spravodlivý proces, s ktorým musí byt' akákol’vek forma automatizácie v súlade.
\end{abstract}

\section{KLUUČOVÉ SLOVÁ}

Automatizácia; automatizované rozhodovanie; právo na spravodlivý proces; l'udské práva; digitalizácia spravodlivosti; robosudcovia

\footnotetext{
1 Tento článok vznikol na Masarykově univerzitě v rámci projektu "Právo a technologie IX" číslo MUNI/A/1292/2020 podporeného z účelovej podpory na špecifický vysokoškolský výskum poskytovanej Ministerstvem školství v roku 2021 a vychádza z autorovej diplomovej práce "Vybrané aspekty práva na spravedlivý proces a automatizace rozhodování" (dostupná z: https://is.muni.cz/auth/th/vpo5j/).

2 Mgr. Andrej Krištofík je doktorandem na Ústavu práva a technologií Právnické fakulty Masarykovy univerzity. E-mail: andrejkristofik@gmail.com
} 


\begin{abstract}
With a continuous advance of technological development, we can observe their gradual introduction into the legal proceedings and court rooms where they fulfil different judge supporting roles. The extent to which this role can be expanded is not only technological, but legal question as well. The basic legal framework for any advances in judicial decision making is set mostly by the right to a fair trial. This right is then the primary focus of the work, analysing the impact of automation on the timeliness of proceedings, and access to a court. With the analysis of im-partiality and bias this work introduces technical aspects of these issues, following up with the analysis of the right to a public hearing and the remaining collection of fair trial rights. In the last category, the right to a reasoned judgement is to focal point. Jointly, these aspects represent the right to a fair trial and any form of technological advancement in this field must be compliant with it.
\end{abstract}

\title{
KEYWORDS
}

Automation; Automated Decision Making; Right to a Fair Trial; Human Rights; Digital Justice; Robojudges

\section{ZOZNAM POJMOV A SKRATIEK}

ESL'P Európsky súd pre l’udské práva

FRA Európska agentúra pre základné l’udské práva

Listina Ústavní zákon č. 2/1993 Sb. ve znění ústavního zákona č. 162/1998 Sb., listina základních práv a svobod

Ústava Ústavní zákon č. 1/1993 Sb., Ústava České republiky

Dohovor Európsky dohovor o l’udských právach

ODR Online Dispute Resolution

Panel High-Level Expert Group on Artificial Intelligence

GDPR Nariadenie Európskeho parlamentu a Rady 2016/679 o ochrane fyzických osôb pri spracúvaní osobných údajov a o vol'nom pohybe takýchto údajov, kto 
rým sa zrušuje smernica 95/46/ES (všeobecné nariadenie o ochrane údajov)

\section{1. ÚVOD}

Bude to takmer 50 rokov, odkedy jednoslovná odpoved’ „Nič“ Johna McCarthyho, jedného zo zakladatel’ov výskumu umelej inteligencie, spustila úvahy o „robosudcoch“. Touto odpoved’ou reagoval na otázku, ktorá mu bola položená v diskusii s Jospehom Weizenbaumom - „Čo také vie sudca, čo by sme eventuálne nemohli naučit aj stroj?“. 33

O Tri roky neskôr McCarty, tentokrát Thorne, naprogramoval TAXMAN - softvér, ktorý mal na základe vtedy ešte len vznikajúcich princípov umelej inteligencie analyzovat’ „monotónne“ daňové prípady. Záverom štúdie, ktorej súčastou bol tento softvér, McCarty uvádza rozsiahle obmedzenia tohto programu, ktoré ho robia prakticky nepoužitel'ným, no považuje ho za začiatok vývoja takýchto právnych analytických systémov. ${ }^{4}$

Necelých 50 rokov, rokov, ktoré by podl’a Moorevoho zákona mali predstavovat’ viac než dost’ času, ${ }^{5}$ však podl'a všetkého nestačili k naplneniu týchto optimistických očakávaní. Je otázne, či sa jedná „len“ o technické nedostatky, a pomaly sa uberáme k vývoju takýchto komplexných sudcovských systémov alebo je tento problém omnoho komplexnejší než McCarthy predpokladal.

Ani na jednu z týchto otázok táto práca neodpovie, z časti sa však pozrieme na to, „čo také vie sudca, čo nenaučíme stroj“, aj ked’ vhodnejšie by bolo „Je taká zložka súdneho systému, ktorú nemožno vyjadrit algoritmicky?“. Akúkol'vek (futuristickú) formu súdneho procesu zvolíme, jedna vec v nej musí vždy ostaţ zachovaná - a to právo na spravodlivý proces. V nasledujúcej práci sa budeme venovat otázke, či je možné splnit všetky

3 McCorduck, P. Machines Who Think: A Personal Inquiry into the History and Prospects of Artificial Intelligence. Boca Raton: Routledge \& CRC Press, 2004, s. 375.

4 McCarty, L. T. Reflections on TAXMAN: An Experiment in Artificial Intelligence and Legal Reasoning. Harvard Law Review. 1977. https://www.researchgate.net/publication/ 259872868

5 Lewis, P. J. D., Ted G. Exponential Laws of Computing Growth [online]. [cit 8. 3. 2021]. https://cacm.acm.org/magazines/2017/1/211094-exponential-laws-of-computing-growth/ fulltext 
nároky práva na spravodlivý proces aj $\mathrm{v}$ plne automatizovanom súdnom rozhodovaní.

Za účelom tejto analýzy je potrebné najprv rozobrat pojem práva na spravodlivý proces, ktoré je samo o sebe velmi komplexnou problematikou a ako také vlastne ani nie je právom ako takým . Právo na spravodlivý proces je súborom množstva zložkových práv, ktorých kombinácia garantuje spravodlivý proces. V prvej časti tohto článku bude preto čitatel’ovi poskytnutý výklad tohto práva, ktorého výsledkom by malo byt založenie doktrinálneho chápania, aké jednotlivé aspekty spoločne toto právo tvoria.

Článok sa zameria na interpretáciu práva na spravodlivý proces v kontexte krajín Európskeho dohovoru o ludských právach. Základným dokumentom bude preto Európsky dohovor o l’udských právach a zároveň aj Listina základných práv a slobôd Českej republiky, ktorá existuje v rámci priestoru, ktorý pre právo na spravodlivý proces vymedzuje Dohovor, jeho začlenenie do analýzy teda pomôže rozšírit interpretáciu tohto práva o národnú perspektívu a priblížit niektoré body, ktorým sa v Dohovore, ako svojím charakterom skôr abstraktnejšom dokumente, nedostalo tol'ko

priestoru.

Právo na spravodlivý proces bude $\mathrm{v}$ tejto práci chápané $\mathrm{v}$ intenciách týchto dvoch dokumentov, $\mathrm{k}$ ich výkladu bude potom použitá komentárová literatúra, judikatúra Európskeho súdu pre ludské práva a Ústavného súdu Českej republiky, podporne aj teoretické práce o práve na spravodlivý proces ako takom.

Ciel’om tejto časti práce bude najmä založit doktrinálne chápanie jednotlivých zložkových aspektov, ktoré toto právo tvoria. Bežne je toto právo chápané bud'to $\mathrm{v}$ kontexte trestného alebo civilného (resp. akéhokol'vek netrestného) procesu. Takéto delenie pre tento článok nebude podstatné, kedykolvek je aspekt možné považovat za doktrinálny, bude zahrnutý do bližšieho posúdenia. $\mathrm{K}$ d’alšej analýze bude pristúpené s ohl'adom na tieto jednotlivé aspekty.

Než sa dostaneme k hlavnej časti, ktorou je konfrontácia možností automatizácie s právom na spravodlivý proces, bude čitatel v krátkosti oboznámený s pojmom automatizácie. Automatizácia je vel’mi široký pojem 
a s ohl'adom na zameranie tohto článku sa bude jednat’ iba o krátke predstavenie pre potreby d’alšej analýzy, zároveň je však pojem automatizácie chápaný vel’mi obšírne a neviaže sa na žiadny konkrétny technický spôsob prevedenia. Rozhodujúce pre túto prácu je, že prostredníctvom algoritmizácie rozhodovacieho procesu absolútne odstraňujú potrebu l’udského zásahu. ${ }^{6}$ Za splnenia tejto podmienky je potom jedno, či sa bude jednat o dierny štítok ${ }^{7}$ alebo o generatívne kontradiktórne siete. ${ }^{8}$

Po týchto dvoch častiach bude už pristúpené k samotnej podstate, teda posúdenia vplyvu automatizácie na jednotlivé aspekty práva na spravodlivý proces. Z takéhoto posúdenia budú vopred vylúčené rôzne faktory, ktoré síce v súčasnosti ovplyvňujú právo na spravodlivý proces, no s procesom ako takým vlastne nesúvisia, a teda neexistuje žiadny dôvod predpokladat ich ovplyvnenie automatizáciou, nebolo by vel'mi o čom písat. Príkladom je imunita, ktorá síce zasahuje do práva na prístup k súdu, no jej samotná podstata nevyplýva z procesných pravidiel a nie je dôvod sa domnievat', že by bola ovplyvnená automatizáciou.

Každá z podkapitol, teda každé posúdenie individuálneho aspektu, obsahuje čiastkový záver reflektujúci možnosti a otvorené otázky vplyvu automatizácie na tento aspekt.

V poslednej časti sa budeme venovat legislatívnej úprave tohto problému, a to v dvoch častiach. Najprv bude čitatel' oboznámený so súčasnou právnou úpravou, ktorá sa zameria primárne na úpravu v rámci krajín

6 Slovom „absolútne“ sú teda vylúčené ,judge supporting“ systémy, ktoré nemožno považovat za úplnú automatizáciu. O takýchto systémoch bude na niektorých miestach tejto práce pojednaní, nakol'ko sú príkladom (čiastočnej) automatizácie, ktorú môžem pozorovat $\mathrm{v}$ súdnych sieňach už v súčasnosti, a je možné ich považovat za vhodný prvý krok k širšej automatizácii, ich vztah k právu na spravodlivý proces však nebude relevantný pre vyslovenie záveru tejto práce.

7 Ako príklad prvého pokusu o automatizáciu ludských činností, vid’: Lauren, C. A Brief History of Automation [online]. Scadata. 30. 8. 2016 [cit 9. 3. 2021]. https://scadata.net/brief-history-automation/

8 Ako príklad momentálne posledného prístupu k strojovému učeniu, ktorý implementuje rozhodovacie stratégie, vid: Xue, Y., Van Hoeve, W.-J. Embedding Decision Diagrams into Generative Adversarial Networks. V: Rousseau, L.-M., Stergiou, K. (ed.). Integration of Constraint Programming, Artificial Intelligence, and Operations Research. 11494. Cham: $\begin{array}{llll}\text { Springer International Publishing, } 2019 & \text { [cit 9. 3. 2021]. }\end{array}$ http://link.springer.com/10.1007/978-3-030-19212-9_41 
Rady Európy. Podporne budú použité aj úpravy z iných krajín, ak bude táto úprava vhodná pre otázky v tomto článku. V druhej časti bude navrhnutých niekol'ko bodov vhodných $\mathrm{k}$ budúcej legislatívnej úprave. Celá táto práca však predpokladá možnost’ „hladkého“ prechodu k súdnej automatizácii, to znamená, že všetky aspekty, ako aj ich automatizácia, budú posudzované v rozsahu existujúcich procesných noriem a pre vyslovenie kladného záveru tejto práce je potrebné, aby automatizované systémy mohli fungovat bez ich zmien. Návrh sa preto nebude týkat úpravy procesných noriem, ale pridružených noriem, ktoré sa vztahujú iba na implementáciu automatizovaného systému.

Automatizácia súdneho rozhodovania je komplexný problém, čo si musel uvedomovat pri svojej jednoslovnej odpovedi aj McCarthy. Táto práca sa zameriava výhradne na otázky spojené s právom na spravodlivý proces, a aj to len na jeho doktrinálne aspekty, ktoré nie sú vyčerpávajúce. ${ }^{9}$

\section{PRÁVO NA SPRAVODLIVÝ PROCES A JEHO VYBRANÉ}

\section{ASPEKTY}

Základom tejto práce je právo na spravodlivý proces ako neoddelitel’ná súčast’ právneho systému, ktorá je ako jediná čast’ tejto práce kodifikovaná. Zároveň je to právo na spravodlivý proces, ktoré bude podrobované analýze vo svetle automatizácie súdneho rozhodovania. V tejto časti bude čitatelovi predstavený koncept tohto práva, tak ako je chápaný v Európskom dohovore o l’udských právach a Listine základných práv a slobôd Českej republiky. Každý z týchto dokumentov má v nasledujúcom texte vlastnú podkapitolu a v závere sú predstavené d’alšie zdroje pojednávajúce o tomto práve, nad rozsah týchto dvoch dokumentov.

\footnotetext{
K analýze automatizovaného rozhodovania správnymi orgánmi, ktoré sa neobmedzuje len na právo na spravodlivý proces vid: FIALOVÁ, Eva. Algoritmické rozhodování orgánů veřejné moci [online]. Brno, 2017 [cit. 2021-03-19]. Dostupné z: $<$ https://is.muni.cz/th/xfw84/>. Rigorózní práce. Masarykova univerzita, Právnická fakulta.
} 


\subsection{ZÁKLADNÉ VYMEDZENIE}

Právo na spravodlivý proces predstavuje procesnú garanciu umožňujúcu jednotlivcovi domáhat sa ostatných práv, ktoré mu prináležia. Jedná sa o procesný nástroj, ktorý zaručuje, že hmotné právo a s ním spojené nároky jednotlivca neostávajú len teoretickým konceptom, ale existuje reálna šanca ich uplatnenia. ${ }^{10}$

Jedná sa o jedno z najstarších práv a jeho vývoj je nesporne vel’mi zaujímavý. ${ }^{11}$ Tento článok však nemá byt pojednaním o práve na spravodlivý proces ako takom, preto sa vymedzí na definovanie tohto pojmu a jeho jednotlivých aspektov, tak ako sú doktrinálne chápané v kontexte českého a európskeho práva. Primárnymi dokumentami pre pochopenie tohto práva bude teda Ústava ČR (d’alej tiež „Ústava“), respektíve Listina základných práv a slobôd ${ }^{12}$ (d’alej tiež „Listina“) a Európsky dohovor o ludských právach ${ }^{13}$ (d’alej tiež „Dohovor“). Sekundárne budú pre túto prácu ako zdroj slúžit odborné pojednania nadväzujúce na tieto dva dokumenty.

Pre krajiny, ktoré sú stranou Dohovoru, predstavuje tento dokument minimálny štandard, ktorý musia štáty poskytnút osobám domáhajúcim sa svojich práv súdnou cestou. ${ }^{14}$ Práve $\mathrm{z}$ tohto dôvodu je pre skúmanie problému automatizácie súdneho rozhodovania primárne posúdenie tejto úpravy vel'mi vhodné, nakol'ko ak nebude možné dodržat ani túto minimálnu požiadavku na právo na spravodlivý proces, aký predstavuje pre štáty Dohovor, nemá d’alej zmysel skúmat̉ naplnenie týchto požiadaviek na národnej, či inak špecifickej úrovni.

Ďalšiu pre túto prácu relevantnú definíciu nájdeme v Listine. Na rozdiel od Dohovoru toto právo nie je upravené len na jednom mieste, ale je zachytené naprieč piatou hlavou Listiny, v článkoch 36 - 40. Česká úprava

10 Bartoň, M., et al. Základní práva. Praha: Nakladatelství Leges, s.r.o., 2016, s. 509.

11 Molek, P. Právo na spravedlivý proces. Praha: Wolters Kluwer, 2012, s. 18 - 27.

12 Zákon č. 1/1993 Sb., Ústava České republiky.

13 Európsky dohovor o l’udských právach, v znení protokolov č. 11 a 14. Rada Európy.

14 Kmec, J. Právo na spravedlivý proces (čl. 6 EÚLP). In: Kmec, J. et al. Evropská úmluva o lidských právech. Komentár̆. Praha: C.H. Beck, 2012, s. 572. 
obecne nie je tak jednoznačná ako tá Európska a to nielen kvôli tomu, že neoperuje s termínom "právo na spravodlivý proces", ale aj $\mathrm{z}$ toho dôvodu, že táto čast̉ opisujúca štandardne právo procesného charakteru obsahuje aj niektoré hmotnoprávne záruky. ${ }^{16} \mathrm{O}$ takomto usporiadaní sa často hovorí, trochu paradoxne, ako o „hmotnoprávno spravodlivom procese“ a to aj navzdory faktu, že samotné základné ustanovenie tejto časti, článok 36, používa termín „stanovený postup“, teda vyslovene garantuje záruku postupu (procesu) a nie (hmotnoprávneho) výsledku. ${ }^{17}$

\subsubsection{BLIŽŠIE POJEDNANIE K ČLÁNKU 6 DOHOVORU}

Článok 6 je tzv. kvalifikované právo, teda zo strany zmluvného štátu je možné doň zasiahnut', resp. ho obmedzit. Aj napriek tomu má však výsostné postavenie v demokratickej spoločnosti - ako sa opakovane vyslovil Európsky súd pre luudské práva (d’alej len „ESLP'“), a teda k jeho výkladu je nutné pristupovat čo najextenzívnejšie. ${ }^{18}$ Možno práve jeho extenzívny výklad prispieva k skutočnosti, že sa jedná o najčastejšie namietané právo pred ESL'P. ${ }^{19}$

Právo na spravodlivý proces je komplexným právom, resp. sa dá povedat, že tento termín nie je právom ako takým, ale jedná sa o termín, ktorý zastrešuje hned' niekol'ko práv, a to aj napriek tomu, že v Dohovore $\mathrm{v}$ porovnaní s Listinou nie je vyjadrené viacerými článkami. ${ }^{20}$ O skutočnosti, že tento článok v sebe zahŕňa hned’ niekol'ko rôznych práv,

15 Tento termín sa neobjavuje v základných právnych dokumentoch, avšak tento termín sa v praxi či akademickom prostredí využíva a rozumejú sa ním tie práva, ktoré sú zakotvené práve $\mathrm{v}$ týchto článkoch Ústavy.

${ }^{16} \mathrm{~V}$ rozhodovacej praxi Ústavného súdu môžeme potom často pozorovat preskum výkladu hmotného práva v rámci stažnosti na porušenie spravodlivého procesu prostredníctvom konceptov „rozporu s princípom spravodlivosti“ alebo „prepätého formalizmu“.

17 Bartoň, M., et al. Základní práva. Praha: Nakladatelství Leges, s.r.o., 2016, s. 509 - 510.

${ }^{18} \mathrm{~K}$ tomu vid' napr: Golder proti Spojenému královstvu, rozsudok Európskeho súdu pre ludské práva, 21.02.1975 č. stažnosti 4451/70 alebo Perez proti Francúzsku, rozsudok Európskeho súdu pre l’udské práva, 12.02.2004 č. stažnosti 47287/99

19 ECHR. Overview 1959 - 2018 [online]. Štrasburg: Council of Europe, 2019, 12 s. [cit. 02.03.2020]. https://www.echr.coe.int/Documents/Overview_19592018_ENG.pdf

${ }^{20} \mathrm{~K}$ tejto myšlienke sa ESĹP vyslovil v prípade Golder proti Spojenému královstvu kde uviedol, že článok 6 zahŕňa síce rozdielne práva avšak všetky z nich (do tohto článku) spája rovnaká základná myšlienka 
ktoré však do tohto článku spája spoločná základná myšlienka (predstavovaná spravodlivým procesom), sa ESL’P vyslovil v prípade Golder proti Spojenému král'ovstvu a d’alej tiež dodal, že toto právo inak nie je bližšie špecificky definované. Z toho nám vyplýva, že ak sa chceme d’alej rozprávat’ o tomto článku, je na mieste identifikovat’ jeho jednotlivé zložky. ${ }^{21}$ Ani na týchto však nepanuje úplný konsenzus, preto bude čitatel' oboznámený s viacerými výkladmi, ktorých následný priesečník určí aspekty tohto článku.

Bartoň vo svojom pojednaní uvádza, ${ }^{22}$ že ide o právo, ktorého základným princípom je právo na prístup $\mathrm{k}$ súdu, ${ }^{23}$ teda asi nie prekvapivo je elementárnou zložkou tohto práva možnost’ súdne konanie vôbec zahájit.. $^{24}$ Ďalej však uvádza, že právo na prístup k súdu je len akýmsi začiatkom práva na spravodlivý proces a identifikuje d’alšie jeho súčasti, ktoré na práve na prístup k súdu stavajú, a to konkrétne práva súvisiace s organizáciou a zložením súdu (vo svojej podstate teda otázky nestrannosti a nezávislosti) a priebehom konania, teda samotnými procesnými pravidlami. $^{25}$

S obecným sentimentom nedefinovatel'nosti práva na spravodlivý proces sa stotožňujú aj Leanza a Pridal vo svojej práci The Right To a Fair Trial. ${ }^{26}$ To neodôvodňujú jeho skladbou zastrešujúcou hned' niekol'ko čiastkových práv, ale najmä pre absolútnu nedefinovatel'nost̉ samotnej spravodlivosti, teda jednej z dvoch súčastí práva na spravodlivý proces. Naproti tomu však

${ }^{21}$ Takýto názor, teda že samotná definícia práva na spravodlivý proces je nedosiahnutelná a teda správnym postupom k jej priblíženiu je rozbor jeho súčastí, možno pozorovat obecne v akademickom prostredí. K tomu vid’ napr.: Kılınç, B. A Trial to Understand the Concept of Fair Trial. Selçuk Üniversitesi Sosyal Bilimler Enstitüsü Dergisi. 2016, č. 35.

22 Bartoň, M., et al. Základní práva. Praha: Nakladatelství Leges, s.r.o., 2016, s. 520.

23 Bartoň v tejto časti užíva termín „právo na súd“, týmto termínom sa označuje právo na prístup k súdu, čo je tiež termín ktorý sa častejšie objavuje v ostatnej odbornej, a najmä zahraničnej literatúre. $\mathrm{V}$ tejto práci budem používat termín právo na prístup k súdu, ktoré je totožné s právom na súd.

${ }^{24} \mathrm{~K}$ tomu potom trefne uvádza Molek (Právo na spravedlivý proces, s. 74), že ak nie je proces, nemôže byt’ ani spravodlivý.

$25 \mathrm{~V}$ tomto sa Bartoň opätovne odkazuje na rozsudok Golder proti Spojenému královstvu.

${ }^{26}$ Leanza, P., Pridal, O. The Right to a Fair Trial: Article 6 of the European Convention on Human Rights. Netherlands: Kluwer Law International. 
Leanza a Pridal zastávajú pozíciu, že navzdory nedefinovatel’nosti pojmu spravodlivost' je možné povedat’ ako ju dosiahnut', a to konkrétne prostredníctvom (spravodlivého) procesu. Spravodlivostou je vich ponímaní teda to, $\mathrm{k}$ čomu sa dospeje spravodlivým procesom. ${ }^{27}$ Podobne ako Bartoň dávajú dôraz na zložku „procesu“, z čoho potom vyplýva, že aj $\mathrm{v}$ ich čiastkovom rozklade tohto práva na jeho jednotlivé aspekty môžeme sledovat' určité prekrytie.

V ich ponímaní sa právo na spravodlivý proces, tak ako je zakotvené v článku 6 Dohovoru, skladá z nasledovných častí: a) právo na prístup k súdu, b) právo na nezávislý, nestranný (a kompetentný) súd, c) verejnost’ pojednávania, d) stanovenie dôkazných (a d’alších procesných) pravidiel, e) právo na včasné konanie, f) právo na zastúpenie a prekladatela. ${ }^{28}$

Rozklad článku 6 na v podstate podobné práva, aj ked’ možno inak kategorizované, či pomenované, podáva aj Harris. ${ }^{29}$ Ten opätovne odkazuje na procedurálny charakter tohto práva, avšak $\mathrm{v}$ porovnaní s ostatnými ho vyvodzuje z rozhodovacej činnosti ESL’P, ktorý pripúšta zásah do hmotnoprávneho výsledku iba v prípadoch takého narušenia, ktoré ovplyvňuje procesnú stránku, ako sú napríklad pochybenie vo faktoch, či jednoznačná arbitrárnost rozhodnutia. ${ }^{30}$ Všeobecne je teda možné povedat', že sa jedná ako o garanciu procesu tak aj výsledku, avšak to iba v tom zmysle, že výsledok musí byt dosiahnutý spravodlivým procesom. ${ }^{31}$

Podobne ako u všetkých predchádzajúcich autorov, aj Harris ako prvý aspekt tohto práva uvádza a) právo na (efektívny) prístup k súdu. Nasledujú ho potom d’alšie práva, na ňom stavajúce ako b) právo na spravodlivé konanie ${ }^{32}$, c) verejnost̉ konania, d) včasnost’ konania, e) právo na nezávislý a nestranný súd (založený zákonom).

27 Ibid., s. 4

28 Ibid., s. 5.

${ }^{29}$ Harris, D., O’Boyle, M., Warbrick, C. Law of the European Convention on Human Rights. New York: Oxford University Press, 2009. s. $201-330$.

${ }^{30}$ V tomto pozorovaní sa Harris odkazuje na prípad Camilleri proti Malte, rozsudok Európskeho súdu pre l’udské práva, 16.03.2000 č. stažnosti 51760/99. V takomto prístupe môže tiež čitatel' sledovat podobnost' s konceptom „hmotnoprávne spravodlivého procesu“ akú používa Ústavný súd, vid’ vyššie.

31 Zrovnaj s definíciou spravodlivosti ako výsledku spravodlivého procesu u Leanzy a Pridala. 
Akokol'vek sa môže názor na konceptuálnu skladbu práva na spravodlivý proces líšit naprieč autormi, je možné sledovat’ v týchto rozkladoch do značnej miery určitý prienik, najmä z dôvodu, že vel'ká časť týchto názorov stavia priamo na judikatúre ESL'P.

Aspekty tvoriace článok 6 sú aj z pohl’adu Kmeca relatívne obdobné. V komentári medzi ne radí a) právo na prístup k súdu, b) nezávislý a nestranný súd, c) právo na včasné prejednanie veci, d) právo na zákonný súd, e) právo na spravodlivé konanie. ${ }^{33}$

Môžeme teda pozorovat', že aj napriek reálnej nedefinovatel'nosti konceptu práva na spravodlivý proces obsiahnutého v článku 6 Dohovoru, panuje do určitej miery aspoň konceptuálna zhoda ohl’adom práv, ktoré sú v tomto zastrešujúcom práve skryté.

\subsubsection{BLIŽŠIE POJEDNANIE K LISTINE}

Ako bolo uvedené v úvode tejto kapitoly, právo na spravodlivý proces v Listine nie je singulárnym právom, respektíve jeho úprava je zahrnutá naproti Dohovoru vo viacerých článkoch a to najmä potom v článkoch Hlavy V. Absolútny základ tohto práva však možno hl'adat' ešte skôr, respektíve aj na iných miestach, a to konkrétne v článku 4, ktorý súdnej moci zveruje ochranu základných práv (uvedených $\mathrm{v}$ Listine). Túto právomoc potom tiež rozširuje článok 90 Ústavy, ktorý stanovuje právomoc súdov poskytovat ochranu právam všeobecne.

Právo na spravodlivý proces je v Listine predstavované celým komplexom práv, z ktorých žiadne nie je ako také označené, no v judikatúre Ústavného súdu je tak označovaný súbor práv a garancií predstavujúcich procesné záruky a nachádzajú sa prevážne v Hlave $\mathrm{V}$, a to

\footnotetext{
${ }^{32}$ Na prvý pohlad sa táto kategória môže javit ako totožná so samotným právom na spravodlivý proces, tento aspekt je však podla Harrisa tzv. zostatkovou kategóriou, v ktorej sa posudzujú všetky d’alšie aspekty procesu, resp. ich vplyv na spravodlivost̉ procesu a to v jeho celom kontexte. Ako príklad tu Harris uvádza rovnosṫ zbraní a iné procesné pravidlá alebo odôvodňovanie rozsudkov.

${ }^{33} \mathrm{Kmec}$, J. et al. Evropská úmluva o lidských právech: komentáŕ. Praha: Nakladatelství C. H. Beck, 2012. s. $565-836$.
} 
nie len explicitne, ale aj tak ako ich v týchto ustanoveniach vykladá Ústavný súd alebo ESL’P. ${ }^{34}$

Pospíšil v komentári k Listine ${ }^{35}$ uvádza, že v jednotlivých článkoch súhrnne tvoriacich právo na spravodlivý proces je možné nájste tieto aspekty, a) právo na prístup k súdu, b) právo na nestranný a nezaujatý súd, c) právo na spravodlivé konanie ${ }^{36}$, d) rovné procesné podmienky, ${ }^{37}$ e) verejnost' konania, f) včasnost' konania. ${ }^{38}$

Väčšina zvyšných akademických pojednaní o práve na spravodlivý proces v Listine nám do značnej miery ulahčuje hladanie prieniku aspektov zahrnutých v Listine a Dohovore, nakol'ko ich výklad poskytujú zároveň, a teda identicky, s výkladom Dohovoru, čo len svedčí o univerzálnosti chápania tohto zdanlivo nedefinovatel’ného práva. Príkladom môže byṫ Bartoň, ktorý sa nevenuje bližšiemu rozboru jednotlivých aspektov tohto práva v Listine, ale pri následnom bližšom rozbore aspektov identifikovaných v Dohovore uvádza aj ich pozíciu v Listine, teda vopred pre nás pripravil následne vyzerajúcu syntézu týchto aspektov, a) právo na prístup k súdu, b) nezávislost’ a nestrannost' súdu, c) verejnost', d) spravodlivé konanie, e) včasnost konania. $^{39}$

Ako posledná bude na tomto mieste zmienená teoretická analýza Pavla Moleka v diele Právo na spravodlivý proces, ${ }^{40}$ z ktorého bude nižšie v tomto článku čerpané pri rozbore jednotlivých aspektov. Toto právo tu rozdel’uje na a) právo na prístup k súdu, b) aspekty tvoriace požiadavky na

34 Bartoň, M., et al. Základní práva. Praha: Nakladatelství Leges, s.r.o., 2016, s. 512.

35 Wagnerová, E. et al. Listina základních práv a svobod. Komentár̆. Praha: Wolters Kluwer, 2012.

36 Predchádzajúce tri aspekty sa podla Pospíšila nachádzajú v článku 36 Listiny, respektíve jeho prvom odstavci. Pospíšil rozoberá aj zvyšné dva, z ktorých jeden zakladá správne súdnictvo a druhý upravuje zodpovednosţ štátu. Tieto časti teda nepredstavujú aspekt práva na spravodlivý proces ale rozširujú, či upravujú jeho aplikáciu a preto nie sú pre potreby tejto práce relevantné. Podobne potom aj odstavec 4 tohto článku.

37 Obsiahnuté v článku 37, zahŕňajú rovnost̉ zbraní alebo odopretie výpovede, teda podstatnou zložkou je nie len rovnost' ale aj vôbec stanovenie procesných podmienok.

38 Wagnerová, E. et al. Listina základních práv a svobod. Komentár̆. Praha: Wolters Kluwer, 2012, s. 725 - 830.

39 Bartoň, M., et al. Základní práva. Praha: Nakladatelství Leges, s.r.o., 2016, s. 519 - 566.

40 Molek. Právo na spravedlivý proces, 2012. 
súdy a sudcov, ${ }^{41}$ c) včasnost', d) aspekty tvoriace požiadavky na priebeh konania. ${ }^{42,43}$

S ohl'adom na stále sa opakujúce koncepty v týchto rozboroch, a to bez ohl’adu na to, aký majú právny základ, je jasné, že samotná nedefinovatel'noste tohto práva by nemala predstavovat problém pri identifikácii jeho jednotlivých zložkových aspektov, ku ktorej bude pristúpené v nasledujúcej podkapitole.

\subsection{DOKTRINÁLNE ASPEKTY PRÁVA NA SPRAVODLIVÝ PROCES}

Pre určenie doktrinálnych aspektov práva na spravodlivý proces je samozrejme nevyhnutné posudzovat aspekty vztahujúce sa $\mathrm{k}$ tej istej veci. S ohl’adom na spornost’ otázky začiatku súdneho procesu, najmä v judikatúre ESL'P, budeme posudzovat aspekty vztahujúce sa výhradne na prebiehajúci proces a nie na rôzne fázy prípravných konaní. Rovnako nemá význam zaoberat sa otázkou, čo je (zákonný) súd, alebo tým čo je otázkou trestnou, civilnou alebo inou.

Aspektom, ktorý zmienila každá z vyššie uvedených analýz, je celkom očakávane právo na prístup $\mathrm{k}$ súdu. Logicky za ním by z pohl’adu priebehu súdneho konania mala nasledovat nestrannost' a nezaujatosṫ súdu, spolu s verejnostou konania a vynesenia rozsudku, čo sú opät aspekty, ktoré sme mohli pozorovat vo väčšine rozborov. Ďalším bola včasnost celého súdneho konania, vrátane vynesenia rozsudku a poslednou opakovanou kategóriou bola spravodlivost konania - ako zostatková kategória procesných záruk.

Toto sú aspekty, ktoré možno považovat za doktrinálne a zároveň sú to aspekty, ktoré budú d’alej $\mathrm{v}$ tejto práci konfrontované s procesom automatizácie, ktorý bude predstavený v nasledujúcej časti článku.

\footnotetext{
41 Jedná sa o súhrn aspektov, ktoré sú inde uvádzané odlišne ako nezávislost? a nestrannost? a zákonný súd.

${ }^{42}$ Molek tak označuje súhrn aspektov ktoré boli v predchádzajúcich častiach označené aj ako „spravodlivé konanie“, teda rovnost’ procesných nástrojov, verejnost' alebo odôvodňovanie rozsudkov tvoria niektoré z týchto aspektov.

43 Molek. Právo na spravedlivý proces, 2012, s. 73 - 321.
} 


\section{AUTOMATIZÁCIA ROZHODOVANIA}

\subsection{AUTOMATIZÁCIA}

Druhým podstatným pojmom článku, po práve na spravodlivý proces, je automatizácia rozhodovania. Názov článku obsahuje pojem automatizácia, nakol'ko je omnoho evokujúcejší a je l’ahšie si predstavit riešenie, ktorým sa táto práca zaoberá. Zamenitelne s týmto termínom bude používaný pojem algoritmizácia, čo je zase pojem, na ktorom sa bude lepšie vysvetl'ovat mechanizmus zvažovaného riešenia. Oba termíny však v konečnom dôsledku predstavujú to isté.

Pojem algoritmus býva vel’mi často spájaný takmer výhradne s počítačovým softvérom, a to z toho dôvodu, že práve logická a sekvenčná výstavba, ktorá je vlastná algoritmom, tvorí základ počítačového programovania. ${ }^{44}$ Takáto predstava, akokolvek technicky správna, nezachytáva plný význam tohto pojmu. Tak ako sme aj v predchádzajúcej časti kládli dôraz na proces, tvoriaci kostru práva na spravodlivý proces, tak je možné aj o algoritme uvažovat ako o procese, respektíve ako o jeho opise, a teda do určitej miery identifikovat aj jeho jednotlivé základné súčasti.

Pôvodne sa tento pojem odvodil od výrazu „algorismus“, ktorý označoval spôsob vykonávania výpočtov pomocou arabských číslic. ${ }^{45}$ Modernejšiu verziu definície tohto pojmu môžeme nájst̉ napríklad v príhodne pomenovanej práci Thomasa H. Cormena „Introduction to algorithms“, ktorý vo svojej definícii stále zachováva primárne matematickovýpočtový charakter algoritmu, d’alej ju však stavia ako presne definovaný (výpočtový) proces, ktorý na vstupe prijíma určitú hodnotu, alebo ich set, a následne aplikáciou vopred stanovených procesných krokov transformuje vstupný údaj na údaj, ktorý poskytuje ako relatívne predvídatelný výstup. ${ }^{46}$

Cormenova definícia je už o čosi deskriptívnejšia, avšak aj tá sa stále viaže na matematický charakter algoritmu, to však nemusí byt̉ jeho inhe-

\footnotetext{
${ }^{44}$ Knuth, D., E. Uměmí programování. 1.díl. Základní algoritmy. Brno: Computer Press, 2008, s. 1.

45 Ibid.

${ }^{46}$ Cormen, T., H. et al. Introduction to algortihms. Cambridge: MIT Press, 2009, s. 10.
} 
rentnou vlastnostou a pre potreby tejto práce je omnoho prínosnejšie sa v uvažovaní o algoritmoch posunút ešte o úroveň abstrakcie vyššie.

Skôr než na algoritmus ako výpočtovú operáciu sa budeme sústredit na algoritmus ako preskripciu určitého postupu. Namiesto konkrétneho technického riešenia sa bude článok d’alej zaoberat’ teoretickou stránkou možnosti algoritmizácie súdneho procesu, čiže jeho opisom v pevne stanovených krokoch, ktoré transformujú určité vstupné hodnoty na tie výstupné.

Definíciu, ktorá sa zbavuje matematického základu, nám poskytuje napríklad Knuth, ktorý ju sám označuje za „modernú“. Na začiatok uvádza, že jedným z mnohých vhodných synoným tohto slova môže byt napríklad slovo recept, postup alebo metóda. ${ }^{47}$ Neobmedzuje sa však len na synonymá a d’alej poskytuje už obecný výklad tohto pojmu.

Všeobecne by sme podla neho mali algoritmus vnímat’ ako konečnú množinu pravidiel, ktoré popisujú určitú postupnost’ operácií, ktoré riešia vopred určený, druh problémov. Zároveň podla neho musí algoritmus spĺňat 5 kritérií, ktorými sú: i) konečnost', ii) určitoste, iii) vstup a iv) výstup, v) efektivitu. ${ }^{48}$

Ak by sme chceli príst’ s definíciou, ktorá spája Knuthovu všeobecnú „modernú“ definíciu a predchádzajúce „matematické“ definície a zároveň ignoruje, či k algoritmizácii dochádza jednoduchým flowchartom na papieri alebo komplexným systémom neurónových sietí, môžeme nad algoritmom uvažovat’ ako nad určitým procesom, ktorý sleduje vopred určený druh výsledku, za dosiahnutím ktorého má vopred stanovené určité procesné kroky, cez ktoré prechádza s danými vstupnými údajmi - informáciami, ktoré na začiatku či v priebehu procesu očakáva.

\footnotetext{
47 Pre našu definičnú istotu trochu neštastne uvádza aj to, že takýmto synonymom môže byt? kl’udne aj „blábol“.

48 Knuth. Uměmí programování. 1.díl. Základní algoritmy, s. 4 - 7.
} 


\subsection{AUTOMATIZOVANÉ SYSTÉMY V TEJTO PRÁCI}

Najrozšírenejším, a v podstate jediným reálnym, príklad automatizácie sú v súčasnosti tzv. expertné systémy. ${ }^{49}$ Tie majú za úlohu „rekonštruovat“ odbornost a proces uvažovania vo vel'mi úzko vymedzenom odbore. $\mathrm{K}$ tomuto sa snažia využit heuristické postupy ludskej mysle, ktorá pri tomto „expertnom“ druhu uvažovania vezme základnú vedomost', či údaj, a žiadaný výsledok dostanú aplikáciou určitých sekvenčných krokov. ${ }^{50}$ Vo všeobecnosti používajú tieto systémy vel’mi jednoduchú predikátovú logiku, ktorá sa zjednodušene dá demonštrovat aj postupom „AK ............ POTOM ..............., ktorá môže byt „rozvetvená“ do komplexnej procesnej štruktúry. ${ }^{51}$ Takýmto postupom vedia napodobnit s velkou presnostou a efektivitou ludského experta vo vel'mi úzko vymedzenom poli expertízy. ${ }^{52}$

Takéto systémy sú v kontraste s tzv. širokou, alebo obecnou umelou inteligenciou, ktorej úlohou je dosiahnut aspoň rovnakej inteligencie akou disponuje človek, a to vo všetkých oblastiach, v ktorých je možné určitú mieru inteligencie obecne od človeka očakávat. Je teda jedno, či po takomto systéme obecnej umelej inteligencie budeme chciet aby šoférovala auto alebo hrala šach, jeden systém by mal zvládnut všetky úlohy. Takáto umelá inteligencia je stále len abstraktný koncept a Clune takéto systémy označuje za najambicióznejší vedecký projekt ludstva. ${ }^{53} \mathrm{Z}$ tohto dôvodu takémuto konceptu nebude $\mathrm{v}$ tejto práci venovaný d’alší priestor.

Clune však vo svojej práci ešte poukazuje na iný zaujímavý fenomén a to využívanie umelej inteligencie, k tvorbe iných systémov umelej

${ }^{49} \mathrm{~K}$ rozsahu aplikovatelnosti týchto systémov dávame čitatelovi do pozornosti Expert Systems with Applications periodikum od vydavtel'stva Elsevier, ktoré rozoberá aplikáciu takýchto systémov naprieč skutočne všetkými odvetviami. Vid: https://www.journals.elsevier.com/expert-systems-with-applications/

50 Puppe, F. Systematic Introduction to Expert Systems: Knowledge Representations and ProblemSolving Methods. Berlín: Springer, 1993, s. 5-6.

${ }^{51}$ Nikolopoulos, C. Expert Systems: Introduction to First and Second Generation and Hybrid Knowledge Based Systems. New York: CRC Press - Taylor \& Francis Group, 1997, s. 2-5.

52 Puppe. Systematic Introduction to Expert Systems: Knowledge Representations and Problem-Solving Methods, s. 4.

${ }^{53}$ Clune, J. AI-GAs: AI-generating algorithms, an alternate paradigm for producing general artificial intelligence. arXiv:1905.10985 [cs]. 2020 [cit 18. 3. 2021]. http://arxiv.org/abs/ 1905.10985 
inteligencie. ${ }^{54,55}$ Medzi takéto prístupy $\mathrm{k}$ tvorbe systémov sa radí napríklad aj strojové učenie, u ktorého je možné si predstavit jeho budúce využitie aj k tvorbe rozhodovacích systémov, čo so sebou prináša niektoré unikátne problémy pre právo na spravodlivý proces, ako napríklad problematiku black box algoritmov, ktorej bude venovaná čast’ tejto práce. Umelá inteligencia, resp. automatizácia teda nemusí hrat rolu len pri samotnom výkone súdnej moci ale aj v iných fázach vývoja takýchto systémov.

Tento článok by mal byt všeobecným pojednaním o automatizovaných rozhodovacích systémoch a preto sa nebude vyslovene zameriavat na jeden druh, či konkrétny prípad. Avšak, pre lepšiu predstavu čitatel’a, systém s ktorým budeme konceptuálne narábat’ v tejto práci, je taký, ktorý odstraňuje akúkol'vek potrebu l'udského sudcu (t.j. plná automatizácia). Strany sporu v takomto systéme komunikujú so súdom prostredníctvom užívatel'ského rozhrania, ktoré môže byt̉ prístupné napríklad online, systém potom autonómne vyhodnotí údaje ktoré mu boli stranami takto poskytnuté, a následne vydá a stranám doručí svoje rozhodnutie.

\section{VYBRANÉ ASPEKTY PRÁVA NA SPRAVODLIVÝ PROCES}

\section{A AUTOMATIZÁCIA}

Táto čast’ bude rozoberat hlavnú otázku - teda možnosti zosúladenia automatizácie s právom na spravodlivý proces, ktoré už bolo predstavené vyššie, avšak úvodom tejto časti bude vykonaná identifikácia spoločných definičných aspektov tohto práva podl’a predchádzajúcej časti.

Následne bude tento výber zúžený na tie, ktoré by mohli predstavovat problém pre proces automatizácie a bude ich konfrontácii s automatizáciou bližšie pojednané.

54 Ibid.

55 Expertné systémy sú mnohými autormi radené medzi systémy slabej, resp. úzkej umelej inteligencie, čo je záver s ktorým možno obecne súhlasit, no pre obšírnost’ pojmu umelá inteligencia, ostane táto práca pri termíne expertné systémy. Vid’ napr. Nikolopoulos, C. Expert Systems: Introduction to First and Second Generation and Hybrid Knowledge Based Systems. s $1-3$. 


\subsection{VČASNOSŤ}

Prvým z vybratých kompozičných aspektov práva na spravodlivý proces je včasnost súdneho konania. Z prietahov v súdnom konaní sa tak trochu stáva ich definičný znak sám o sebe ${ }^{56}$ a niekedy sa $\mathrm{z}$ nich môže dokonca stat̉ samotná procesná stratégia. ${ }^{57}$

ESL’P sa v rozsudku H proti Francúzsku vyjadril, že nielenže je včasnost' súčastou článku 6 , ale tiež poskytol názor, že zlyhanie súdov vo včasnom zahájení procesu, respektíve vynesení rozsudku, znižuje nielen ich dôveryhodnost', ale aj samotnú efektivitu spravodlivosti. ${ }^{58}$ Okrem efektívnosti výkonu, ktorá je s ohladom na jej včasnosť často uvádzaná ako jeden z právnych maxím $\mathrm{v}$ anglosaskom prostredí, ${ }^{59}$ Harris d’alej uvádza, že včasnost̉ súdneho konania je podstatná pre zníženie obdobia neistoty, v ktorej sa strany sporu nachádzajú a tiež dížku zásahu do dôveryhodnosti obžalovaného, ku ktorému často pri trestných konaniach dochádza. ${ }^{60}$

Aj napriek faktu, že je včasnost súdneho konania tak podstatnou pre efektívne zabezpečenie spravodlivosti, najčastejšie namietaným porušením práva na spravodlivý proces pred ESL̇P je práve neúmerná dížka súdneho

56 Molek súdnym priełahom prisudzuje nálepku „systémového“ nedostatku. Molek. Právo na spravedlivý proces, s. 295. S vel'kou mierou nadsázky na tento fenomén poukazuje aj Mayaan vo svojej štúdii o meratel'nosti súdnej efektivity, kde úvodom poukazuje nato, že neefektivita súdneho procesu sa stala prirodzenou súčastou anglického jazyka a fráza „sue me“ poukazuje na bezvýchodiskovost’ situácie jej adresáta. Maayan, E., Ronen, B., Coman, A. Assessing the Performance of a Court System: A Comprehensive Performance Measures Approach. International Journal of Public Administration. 2012, č. 11.

57 Wood, J., Allan, N. Sinking the Italian torpedo: the recast Brussels Regulation [online]. International Law Office. 10. 2. 2015 [cit 25. 11. 2020]. https://www.internationallawoffice.com/Newsletters/Litigation/European-Union/RPC/Sinking-the-Italian-torpedo-the-recastBrussels-Regulation

${ }^{58}$ H proti Francúzsku, rozsudok Európskeho súdu pre ludské práva, 24.10.1989 č. stažnosti 10073/82, odstavec 58 .

59 Justice delayed is justice denied. Fremer, R. How to eliminate the setbacks in the proceedings before the international criminal tribunals. New York, 2010. https://www.mzv.cz/file/609107/Judge_Fremr_s_Speech.doc K tomu zrovnaj „Justice hurried is justice burried“ v disentnom stanovisku k Doroshenko proti Ukrajine, rozsudok Európskeho súdu pre ludské práva, 26.05.2011 č. stažnosti 1328/04.

${ }^{60}$ Harris, O'Boyle, Warbrick. Law of the European Convention on Human Rights, s. 278. 
konania ${ }^{61} \mathrm{~V}$ kontexte skutočnosti, že článok 6 je najčastejšie namietaným právom, to vykresluje skutočne tragické postavenie včasnosti v súčasnom súdnictve. ${ }^{62}$ Vel'mi nežiadúce prvenstvo $\mathrm{v}$ súdnych prietahoch má medzi členskými štátmi Dohovoru Taliansko, a to do absolútne ironickej miery, kedy množstvo stažností na súdne prietahy, ktoré boli talianskymi občanmi podávané $\mathrm{k}$ ESL'P, dosiahli takého množstva, že hrozilo vytváranie prietahov v konaniach pred ESL'P a súd ich musel prejednávat súhrnne. ${ }^{63}$

Súdne prietahy, ako vec takmer systémová, sa nevyhýbajú ani Českej republike a dížka konania je v podstate na konštantnom vzraste od roku 2015 a priemerná dížka civilného sporu bola v roku 2019 až 276 dní. Jediné pol'avenie $\mathrm{v}$ tomto trende môžeme pozorovat len vd’aka nižšiemu počtu podaných žalôb. ${ }^{64}$

Stanovenie primeranej dížky súdneho procesu je v zásade nemožné, nakolko každý spor má svoje špecifiká a zvláštne okolnosti, ktoré podmieňujú jeho dížku, načo ostatne upozorňuje aj rozsiahla judikatúra ESL'P v otázke primeranej dížky konania. ${ }^{65}$ To samozrejme neznamená úplnú kapituláciu na možnost úpravy primeranej dížky konania, tá by však podla ESL'P mala byt̉ posudzovaná individuálne na základe niekol'kých kritérí. Rozhodujúcim faktorom je komplexnost’ a zložitost konania, ktorá zohl'adňuje aj množstvo zapojených osôb mimo strany sporu (ako napr. znalci a svedkovia) a tiež počet inštancií, medzi ktoré je doba sporu rozdelená. Ďalej ESL’P zohladňuje aj aktivitu orgánov, napríklad prietahy v predávaní spisov medzi jednotlivými inštanciami a podobné

${ }^{61}$ Edel, F., Council of Europe. La durée des procédures civiles et pénales dans la jurisprudence de la Convention européenne des droits de l'homme. Strasbourg, France: Editions du Conseil de l'Europe, 2007, s. 6.

${ }^{62} \mathrm{~K}$ tomu vid’ napríklad štatistiku porušení podla článku Dohovoru za rok 2019 na: https://www.echr.coe.int/Documents/Facts_Figures_2019_ENG.pdf , prípadne prehladovú štatistiku za 60 rokov fungovania ESLP https://www.echr.coe.int/Documents/Stats_violation_1959_2019_ENG.pdf

${ }_{63}$ Molek. Právo na spravedlivý proces, s. 296.

${ }^{64}$ Paseková, E. Délka civilního řízení loni opět klesla, trestní se prodloužilo [online]. Česká justice. 21. 8. 2019 [cit 27. 11. 2020]. https://www.ceska-justice.cz/2019/08/delka-civilniho-rizeni-loni-opet-klesla-trestni-se-prodlouzilo/

${ }^{65} \mathrm{~K}$ tomu zrovnaj výpočet prípadov v: Molek. Právo na spravedlivý proces, s. 298. 
"administratívne“ zdržania, a takéto obdobné, v podstate svojvol’né vytváranie prietahov posudzuje aj na strane účastníkov sporu, nakol'ko nemožno postihovat štát za chyby niekoho iného. Ďalej by sa mala vhodná dížka jednania odvíjat aj od toho, čo je v „stávke“. Ako bolo už vyššie spomenuté, najmä pri trestnom konaní môže trvajúci spor ohrozovat’ čest’ (nevinných) účastníkov, a je preto žiadúce takýto stav odstránit čo najskôr, respektíve je možné vnímat túto potrebu omnoho naliehavejšie než u iných, napríklad civilných, sporov. ${ }^{66,67}$

Vyššie opísané faktory posudzovania nám môžu vytvorit’ „ospravedlnitel'ný“ prietah v súdnom konaní. ${ }^{68} \mathrm{~S}$ ohl'adom na množstvom Súdom uznaných prietahov v konaní je však zrejmé, že väčšina žalôb nakoniec tieto kritéria nesplní a skutočné, teda „neospravedlnitel'né“ prietahy sú v súčasnosti reálnym problémom súdnych systémov, minimálne v krajinách Dohovoru. Otázkou, ktorá je pre túto prácu zaujímavejšia, než posúdenie dopadu automatizácie na vyššie vymenované kritéria, je otázka skutočného pôvodu týchto neospravedlnitel’ných prietahov a posúdenia, či automatizáciou súdneho procesu nebudú negatívne ovplyvnené, čím by došlo k zhoršeniu už tak nežiadúceho stavu, a sekundárne či náhodou neexistuje šanca, že by došlo k jeho korekcii. ${ }^{69}$

Harris nachádza dve možné vysvetlenia súdnych prietahov, resp. porušenia práva na včasnost’ súdneho konania v rozsudkoch ESL'P. Tým prvým vysvetlením je, že ESL’P má jednoducho prehnané a nerealistické požiadavky na priebeh vnútroštátnych konaní, ktorým je zo svojej pozície príliš vzdialený. Takýto dôvod, ktorý aj sám Harris považuje skôr za menej pravdepodobný, je l'ahké vyvrátit poukázaním na rozsiahlu vnútroštátnu judikatúru európskych krajín, ktorá poukazuje na ten istý problém. Dokázatel'ne teda tento názor nezastáva len ESLP. Ako druhé možné

\footnotetext{
${ }^{66}$ Ibid, s. 299 - 304.

${ }^{67}$ Ako d’alej upozorňuje Molek, tieto isté kritéria očakávatelne preberá aj Ústavný súd.

${ }^{68}$ Ak je možné za splnenia opísaných kritérií vôbec možné o prietahu rozprávat.

${ }^{69}$ Ako upozorňuje Susskind, akákolvvek (technologická) inovácia v súdnictve v zásade nemá zmysel ak má za úloh len napodobnit, či virtualizovat stávajúci systém a nesnaží sa ho do nejakej miery zlepšit, či zefektívnit. Susskind, R. Online courts and the future of justice. Oxford: Oxford University Press, 2019.
} 
vysvetlenie potom Harris uvádza, že sa jedná o všeobecný problém právnych systémov krajín Dohovoru. ${ }^{70}$

S Harrisovým druhým záverom je rozhodne možné súhlasit s ohl'adom na judikatúru ESLP, no je to viac opis problému než jeho odôvodnenie. Podobné „odôvodnenie“ prináša aj ESL’P v rozsudku Bottazi proti Taliansku, kde uvádza, že prietahy v súdnom konaní sú výsledkom systematického zlyhania súdneho systému. Tiež v tomto rozsudku uznal povinnost̉ štátov organizovat vnútroštátne súdnictvo tak, aby bolo schopné dodržat’ povinnost’ včasnosti článku 6.

Sú prietahy v súdnictve teda problémom jeho organizácie? S takýmto záverom čiastočne súhlasí vyššie spomínaná Maayanova štúdia, ktorá rozoberá niekol'ko metrík a prístupov k manažmentu súdnych prípadov, ktoré sú známe skôr z „korporátneho“ sveta ako 6 Sigma a podobne. Tieto manažérske prístupy majú pomôct $\mathrm{k}$ sprehl’adneniu pojednávaní a možnosti ohodnotit ich efektivitu. $^{71}$

Kvantitatívnu štúdiu v otázke súdnych prietahov v Belgicku, ako jednej z krajín viazaných interpretáciou práva na spravodlivý proces Dohovoru, vykonali aj Bielen a Marneffe, podl’a ktorých sa z vel'kej časti prietahy v konaní vyskytujú z dôvodov na strane účastníkov sporu, ako napríklad rôzne odklady či zámerné obštrukcie. Druhou najčastejšou príčinou sú dôvody na strane súdu a sudcov. V tomto ohlade autori štúdie identifikovali dva aspekty činnosti sudcu, ktoré vplývajú na celkovú dížku konania, a tými boli vyhotovovanie rozsudkov a usmerňovanie strán sporu, čiže aktívna/pasívna rola sudcu. ${ }^{72}$

$\mathrm{V}$ českom prostredí možno ako jeden z dôvodov dížky trvania procesu označit aj, už takmer tradičné, pretaženie súdnej sústavy a nedostatok sudcov. $^{73}$

70 Harris, O’Boyle, Warbrick. Law of the European Convention on Human Rights, s. 284.

71 Maayan, Ronen, Coman. Assessing the Performance of a Court System.

72 Bielen, S., Marneffe, W. Are Courts to Blame for Delays in Bel-gian Civil Procedures?: A Decomposition of Case Duration. Jus-tice System Journal. 2017, č. 4, s. 399-420. 
S ohl'adom na vyššie uvedené je možné do určitej miery chápat', prečo sa ESL’P aj Molek, uchýlili k označeniu tohto problému ako systémového, nakol'ko sa zjavne jedná o kombináciu problémov.

Včasnost’ a automatizácia

Identifikácia komplexných systémových problémov, ktoré prispievajú k súčasnému nežiadúcemu stavu dížky súdneho procesu, je nad rámec tejto práce, o to viac potom predstavenie systémového riešenia, ktoré by mohlo tieto problémy odstránit. ${ }^{74}$ Pre vyslovenie záveru v tejto práci nám však stačí identifikovat, či zavedenie automatizovaného súdneho rozhodovania nezhorší, respektíve neovplyvní včasnost' do takej miery, aby bola nezosúladitel'ná s právom na spravodlivý proces.

Jedným z vyššie identifikovaných problémov boli prietahy na strane účastníkov sporu. Riešenie tohto problému je otázkou dizajnu, respektíve vo všeobecnosti je to otázkou procesného práva ako takého viac, než automatizácie. Aj ked’ by bolo možné si predstavit určitý (pozitívny) zásah do tohto problému prostredníctvom pevnejších, napríklad formulárových nastavení častí procesu, ako to môžeme vidiet’ v niektorých $\mathrm{ODR}^{75}$ systémoch

73 K tomu napríklad Paseková, E. Přetížení správního soudnictví se prohlubuje, NSS má přes dva a půl tisíce nevyřízených věcí [online]. Česká justice. 21. 8. 2019 [cit 2. 12. 2020]. https://www.ceska-justice.cz/2019/08/pretizeni-spravniho-soudnictvi-se-prohlubuje-nss-mapres-dva-pul-tisice-nevyrizenych-veci/

74 K tomu vid’ napr. Štúdiu Európskej komisie (update-ovanú k roku 2018) o efektívnosti výkonu justície, v ktorej analyzuje spoločne aj mnohé d’alšie aspekty, ktorými sa zaoberá aj táto práca, ako napríklad prístup k súdu, či transparentnost', čo svedčí o systematickosti a potrebe komplexného riešenia tohoto problému. Hauser, F. et al. Quality of Public Administration - A Toolbox for Practitioners [online]. Shaping Europe's digital future - European Commission. 4. 5. 2015 [cit 17. 3. 2021]. https://ec.europa.eu/digital-single-market/en/ news/quality-public-administration-toolbox-practitioners

75 Pod pojmom Online Dispute Resolution, alebo ODR, sa v tejto práci rozumejú všetky systémy vedenia sporov online, za využitia technológií, bez ohl'adu na ich záväznost', teda či sa jedná o mimosúdne alebo súdne, či iné obdobné konanie. Zároveň sa týmto pojmom bude rozumiet „pokročilá“ virtualizácia sporu, teda primárne taká, ktorá umožňuje jeho asynchrónnoste. To znamená, že ,jednoduché“ presunutie sporu zo súdnej siene na videohovor nie je pre túto prácu ODR. Okrem knihy Susskind, R. Online courts and the future of justice. Oxford: Oxford University Press, 2019., na ktorú je v tejto práci na viacerých miestach odkázané, a ktorá sa zaoberá potenciálom ODR pre budúcnost', odkazujeme čiatel'a aj na publikáciu Loutocký, P. Vymahatelnost práva pomocí online řě̌ení sporů. Praha: Wolters Kluwer, 2020., ktorá sa tomuto pojmu venuje optikou súčasnej právnej úpravy, resp. existujúcich ODR systémov. 
v súčasnosti, ${ }^{76}$ muselo by takéto obmedzenie možnosti obštrukcií zo strany účastníkov sporu vyjst’ z úpravy práva procesného ako takého, a teda toto riešenie nutne nesúvisí s procesom automatizácie. Na druhú stranu nie je dôvod sa domnievat', že by zavedenie automatizovaného procesu inšpirovalo strany $k$ obštrukciám vo väčšej miere, než k nim dochádza v súčasnosti.

Pri problémoch na strane účastníkov sporu teda zrejme nemožno očakávat pomoc od automatizácie súdneho rozhodovania (i ked’ všeobecnejšia virtualizácia súdnych sporov by v tomto mohla hrat rolu). Na druhej strane však tomuto problému ani nepritaží a v podstate túto problematickú zložku môžeme vyhodnotit ako automatizáciou neovplyvnenú.

Omnoho zaujímavejšie však môžu byt̉ prietahy na strane súdu a sudcov, je to napokon ich činnost', ktorá má byt̉ suplovaná automatizáciou. Vo vyššie uvádzanej Maayanovej štúdii boli súdy a ich (ne)činnost’ uvádzaná ako subjektívne najčastejšia príčina prietahov $\mathrm{z}$ pohl'adu advokátov. ${ }^{77} \mathrm{Aj}$ ked’ empirické dáta tohto výskumu nasvedčujú tomu, že to nie je primárny dôvod priet̉ahov, jeho odstránenie by mohlo do vel'kej miery skrátit’ trvanie sporov. Bližšie táto štúdia neidentifikuje problémy spôsobujúce prietahy, nakol'ko jej ciel'om bolo iba všeobecné zostavenie časovej osy súdneho procesu, no z tej môžeme vidiet', že je to samotná rozhodovacia činnost̉ sudcu, spolu s rôznymi čiastkovými procesnými rozhodnutiami, čo zaberá najviac času.

\footnotetext{
${ }^{76}$ Pre ilustráciu vid’ napríklad UDRP systém fungujúci pod Arbitrážnym a Mediačným centrom pre WIPO, ktoré poskytuje ODR pre spory o doménové názvy. K webovému rozhraniu, skrz ktoré konanie prebieha sa síce nedá dostat bez registrácie v systéme no WIPO účastníkom k príprave poskytuje Word dokument, ktorý kopíruje toto rozhranie. Vel'ká čast̉ textu sa v ňom objavuje ako „predpísaný“ odstavec, do ktorého účastník vpíše len relevantné sekcie, prípadne vyberie z ponúkaných možností. Celá komunikácia je rozdelená do jednotlivých bodov, ktoré sú okrem takto predpísaných textov tvorené krátkymi textovými polami, sledujúcimi štruktúru „otázka - odpoved“". Príklad jedného z odstavcov tohto formulára: „Rozporovaná doména je [uved’te názov domény], ktorá je registrovaná u [uved’te názov registrára]. Podla vedomostí stažovatela je doménová zmluva uzavretá v [uved'te jazyk] a stažovatel' [súhlasí/nesúhlasí] aby to bol jazyk sporu." Formulárový dokument dostupný na: https://www.wipo.int/amc/en/domains/guide/\#c

77 Maayan, Ronen, Coman. Assessing the Performance of a Court System.
} 
Riešenie takéhoto problému je opät skôr problémom procesného práva, ak chceme nejakým spôsobom odstránit’ „systematickost“ tohto problému. Ako v predchádzajúcich odstavcoch, aj tu je skôr na mieste si pokladat otázku, či vieme tento stav aspoň do nejakej miery vylepšit prostredníctvom procesu automatizácie, prípadne ak nie, či by zavedenie takéhoto procesu negatívne ovplyvnilo včasnost̉ rozhodovania.

V tomto ohl'ade je vhodné sa pozriet’ na Českú republiku, respektíve na vyššie opísaný problém pretaženia súdov. Jedno z navrhovaných riešení tejto situácie, ktoré je až jednoducho intuitívne, je zvýšenie počtu sudcov. ${ }^{78}$ Takéto riešenie je odpoved’ou na pretaženie súdov, a i ked' určite nie je odpoved’ou na iné systémové problémy, ktoré naprieč krajinami Dohovoru spôsobujú tak rozsiahle omeškania, rozhodne by takýto krok ul'avil súdom a pojednávania aspoň do určitej miery zrýchlil.

Navrhovanie spôsobov, akými by bolo možné zvýšit počet sudcov, je opät nad rámec tejto práce. Aby sme sa však opät vrátili k našej pôvodnej otázke, teda aký je vzt̉ah potencionálnej automatizácie súdneho rozhodovania a prietahov v súdnom procese, je do určitej miery možné nahliadat na automatizáciu podobne ako na navýšenie počtu sudcov, a to cez možnost’ procesovania väčšieho množstva prípadov v kratšom čase, či dokonca simultánne.

Nejedná sa teda o „strieborný náboj“, ktorý by tento problém vyriešil, no je možné rozumne predpokladat', že predstavenie automatizácie do súdneho rozhodovania by skrátilo čas, ktorý je v súčasnosti zo strany sudcov potrebný. Automatizácia teda pre podmienky včasnosti procesu nemôže predstavovat’ prekážku.

\subsection{PRÁVO NA PRÍSTUP K SÚDU}

Rozprava o práve na spravodlivý proces prakticky stráca akýkolvek význam, ak nie je zaistené právo na prístup k súdu a do určitej miery ho môžeme nájst’ aj priamo v textovom znení článku $6 .^{79}$ Jedná sa však skôr o kvalifikovaný aspekt práva na spravodlivý proces, nakol'ko krajiny ho

78 Otto, P. Přetížené justici by ulevili dosluhující soudci [online]. E15.cz [cit 3. 12. 2020]. https://www.e15.cz/domaci/pretizene-justici-by-meli-ulevit-dosluhujici-soudci-1368700 
môžu v niektorých prípadoch obmedzit’, to, kedy je to oprávnené, je však často predmetom diskusie či súdnych konaní. ${ }^{80}$ Formálne sa jedná o právo, ktoré je garantované ešte pred započatím súdneho konania. V rozsudku ESL'P, ktorý tento aspekt začlenil pod rozšírenú interpretáciu práv zakotvených v článku 6, Golder proti Spojenému královstvu, mu súd pripísal kl'účovú rolu pri dodržiavaní „vlády práva“. ${ }^{81}$

V Listine naproti tomu nemôžeme nájsţ textovo explicitnú záruku obecného práva na prístup k súdu a obmedzuje sa na túto garanciu len $\mathrm{v}$ sporoch voči orgánom verejnej správy, respektíve v rozsahu správneho súdnictva. To však neznamená, že táto záruka nie je interpretačne dovodzovaná aj v Listine a podl’a Molka sa táto záruka nachádza skrytá pod slovami „se může domáhat stanoveným postupem svého práva“. ${ }^{82}$ Podl’a autora by bolo vhodné k tejto interpretácii doložit ešte slovo „u soudu“, ktorým táto veta $\mathrm{v}$ Listine končí.

Vel'mi zjednodušene sa jedná o právo, ktoré každému zaručuje možnost? iniciovat riadne súdne konanie, také, ktoré nebude len „na oko“ a bude kompletné. Jedným z častých porušení tohto aspektu je, ked’ sa súd, pred ktorým je konanie zahájené, obmedzí iba na procesný či formálny prieskum a neskúma faktické meritum sporu. ${ }^{83}$ Takéto „štepenie“ efektívneho prieskumu spadá pod bližšie rozdelenie (efektívneho) prístupu k súdu, ktorý rozlišuje ESLP a to na prístup „faktický“ (access in fact) a „právny“ (access in law). ${ }^{84}$

79 S týmto názorom Harrisa sa nestotžňuje napríklad Leanza, čo do explicitnosti vyjadrenia tohto práva, no panuje obecný konsenzus na existencii tohto práva v rámci článku 6 Dohovoru.

80 Molek k tomuto uvádza vhodnú poznámku anglického súdu, ktorý právo na prístup k súdu označuje ako také, ktoré má zo všetkých neabsolútnych práv najbližšie k tomu ním byt. Molek. Právo na spravedlivý proces, s. 77.

81 Identický sentiment o panstve práva a právu na prístup k súdu vyjadruje napríklad aj Slovenský ústavný súd v náleze IV. ÚS 60/2010 ktorý vníma zabezpečenie prístupu ako základnú úlohu právneho štátu.

82 Molek. Právo na spravedlivý proces, s. 77.

83 Ibid, s. 78.

84 Tserkva Sela Sosulivka proti Ukrajine, rozsudok Európskeho súdu pre ludské práva, 28.02.2008 č. stažnosti 37878/02. 
Obmedzenia práva na prístup k súdu sa obmedzujú na „právny“ aspekt zavádzaním rôznych, najmä procesných inštitútov, akými je premlčacia lehota u odvolania, alebo rôzne hranice bagatel'nosti sporov a podobne. Takéto obmedzenia samozrejme nemôžu byt’ svojvôlne a musia byt̉ zavedené len za legitímnym účelom a musia byt proporčné tomuto účelu. Tieto obmedzenia tiež nesmú poškodit’ „základný význam“ tohto práva. ${ }^{85}$

Pre posúdenie vztahu medzi automatizáciou a právom na spravodlivý proces, respektíve touto jeho súčastou, bude vhodné, tak ako v predchádzajúcej časti práce, sa zamerat’ na súčasný stav prístupu k súdu, respektíve na jeho súčasné problémy a pokúsit’ sa zhodnotit, aký vplyv by na ne automatizácia mohla mat?.

Podl'a panelu expertov OECD sú v týchto krajinách hlavným problémom prístupu k súdu následné dôvody: a) inštitucionálne, b) sociálne, c) ekonomické, d) kultúrne. ${ }^{86}$

Čo sa týka bližšieho českého (ústavného) kontextu, Pospíšil identifikuje taktiež niekol'ko obmedzení vztahujúcich sa $\mathrm{k}$ právu na prístup $\mathrm{k}$ súdu. ${ }^{87}$ Medzi takéto obmedzenia by malo patrit stanovenie vecnej, funkčnej a miestnej príslušnosti, stanovenie formálnych náležitostí návrhu, požiadavky na zastúpenie, lehoty na podanie žaloby a odvolania, resp. opravných prostriedkov, súdne poplatky, koncentráciu konania a d’alšie formalizované požiadavky na priebeh konania. ${ }^{88}$

Môžeme si všimnút, že prekážky súvisiace s prístupom k súdu sú dvojakého charakteru, bud’to zákonné alebo širšie spoločenské. Analýza spoločenských dôvodov je nepochybne zaujímavá a pre právo podstatná, no zároveň je omnoho komplikovanejšia a vydala by na samostatnú prácu. Z po-

${ }^{85}$ Leanza, Pridal. The Right to a Fair Trial: Article 6 of the European Convention on Human Rights, $s 81-83$.

${ }^{86}$ OECD Expert Roundtable. Equal Access To Justice [online]. OECD. [cit. 10.12.2020]. https://www.oecd.org/gov/Equal-Access-Justice-Roundtable-background-note.pdf

${ }^{87} \mathrm{~V}$ porovnaní s predchádzajúcim odstavcom sa nejedná o problémy brániace prístupu k súdom teda niečo vyplývajúce zo širšieho spoločenského kontextu ale priamo o zákonné obmedzenia tohto prístupu. V českom kontexte pre nedostatok obdobných štúdií môžeme faktické problémy maximálne odvodzovat’ z pokusov o ich zákonnú regulácii v podobe takýchto obmedzení.

${ }^{88}$ Wagnerová et al. Listina základních práv a svobod. Komentár̆, s. 730. 
hladu právnej analýzy je určite jednoduchšie sa zamerat práve na tie zákonné, nakol'ko vyplývajú z písaného práva.

V takomto rámci sa pohybuje aj prehladová štúdia Európskej agentúry pre základné l’udské práva („FRA“), ktorá porovnávala možnosti občanov na prístup k právu vo všetkých členských štátoch. ${ }^{89}$ Na základe tejto kvantitatívnej štúdie FRA identifikovalo niekol'ko elementov, ktoré bud' predstavujú prekážku v prístupe ku spravodlivosti, alebo by členské krajiny na tieto elementy mali vo svojom zákonodarnom procese dávat väčší pozor práve pre ich schopnost̉ ovplyvnit prístup k súdu (vidíme, že sa jedná opät o zákonné a nie spoločenské dôvody). Malo by sa bližšie jednat o a) aktívnu legitimáciu, b) možnosti mimosúdneho riešenia sporov a ich následky, c) právnu pomoc, resp. všeobecne náklady na konanie, d) premlčacie lehoty, e) dížka konania a f) medzinárodné záväzky.

Ak máme utvorený aspoň základný prehl’ad o súčasnom stave prístupu k súdu, je na mieste zaoberat sa otázkou jeho ovplyvnenia automatizáciou súdneho rozhodovania. Táto otázka v sebe (vždy) nesie dve časti, teda či automatizácia nevytvorí novú prekážku prístupu k súdu, prípadne nezhorší niektorú $\mathrm{z}$ existujúcich a ak nie, či je možné prístup $\mathrm{k}$ súdu týmto procesom zlepšit oproti stávajúcemu stavu.

Prvou kategóriou prekážok prístupu k súdu by mali byt inštitucionálne problémy. V rámci tejto kategórie sa podla $\mathrm{OECD}$ nachádzajú rôzne problémy inštitucionálneho usporiadania súdneho systému, ktoré tak povediac „otrávia“ človeka, snažiaceho sa domôct’ spravodlivosti. Najčastejšie sa jedná o neprehl'adnú vnútornú štruktúru inštitúcií spolu s nedostatkom informácií a pomoci pri orientovaní sa v nej, či množstvo jednotlivých úkonov, ktoré je potrebné vykonat. ${ }^{90}$ Vo všeobecnosti takéto obmedzenie práva na súd identifikuje aj Molek s odkazom na rozsudok Hajiyev proti Azerbajdžánu, podla ktorého neprehl’adnost’ a (zbytočná) komplikovanost’ pro-

89 FRA - European Union Agency for Fundamental Rights. access to justice in europe:an overview of challenges and opportunities [online]. Publications Office of the European Union [cit. 18.12.2020]. https://fra.europa.eu/sites/default/files/fra_uploads/1520-report-accessto-justice_EN.pdf

${ }^{90}$ OECD Expert Roundtable. Equal Access To Justice. s. 5. 
cesného práva môže byt๋ vnímaná ako obmedzenie (efektívneho) prístupu k súdu. ${ }^{91}$

Na rolu automatizácie v tomto aspekte prístupu $\mathrm{k}$ súdu môžeme zrejme nazerat dvojako, a to s ohladom na možnú implementáciu do súdneho systému, prípadne jeho reštrukturalizáciu. $\mathrm{V}$ tom konzervatívnejšom, kedy by samotný proces automatizácie hral rolu na pomyselnej časovej osi súdneho procesu až v bode, kedy by štandardne dochádzalo k „ludskému“ sudcovskému rozhodovaniu, sa môžeme domnievat, že by nedochádzalo k žiadnej zmene. Tak, ako musí potencionálny žalobca či účastník sporu aj v súčasnosti „preskákat“" všetky prekážky komplexných súdnych sústav a procesných pravidiel, aby sa do tohto bodu vo svojej ceste za spravodlivostou dostal, čakali by ho aj vo svete automatizovaného súdneho rozhodovania. Ak pripustíme, že súčasný stav prístupu k spravodlivosti, aspoň čo do tejto otázky, je prijatel'ný, nie je dôvod sa domnievat, že proces automatizácie by niečo zmenil.

Ak by sme však chceli pripustit', že súčasný prístup k spravodlivosti nie je úplne ideálny, (aj) kvôli problému komplexnosti procesných pravidiel, je na mieste sa zaoberat aj otázkou, či by nejakým spôsobom mohla tejto situácii pomôct’ automatizácia. Oproti predchádzajúcemu „úzkemu“ scenáru implementácie, je možné si predstavit aj taký, ktorý bude menej konzervatívny a využije digitalizáciu/virtualizáciu procesu obšínejšie. Takáto forma implementácie, ktorá by zároveň mohla osobám snažiacim sa domôct̉ práva ulahčit navigovanie $\mathrm{v}$ súdnom procese, by $\mathrm{v}$ zásade mohla plne využívat princípy ODR, ktoré v súčasnosti prevádzkujú niektoré súkromné entity. Často sa jedná o jeden bod prístupu, webovú stránku, ktorá formulárovým spôsobom naviguje používatel'a cez všetky potrebné kroky, prípadne mu je cez rôzne tooltip-y poskytovat bližšie informácie o tom, čo robí, prípadne, čo by robit mal. ${ }^{92}$ Plné využitie digitalizácie dáva zmysel tiež z dôvodu, že $\mathrm{v}$ určitom bode je nutné vstupné informácie poskytnút algoritmu. Za pred-

91 Molek. Právo na spravedlivý proces, s. 77.

92 Jedným z takýchto ODR systémov, ktorý sa snaží v určitých bodoch nahrádzat súdne riešenie sporu, je napríklad Kleros, dostupné na https://kleros.io/. Ukážka vedenia sporu, respektíve (staršieho) užívatel’ského rozhrania je potom dostupná na https://www.youtube.com/watch?v= PhjcjtYRiDs 
pokladu, že proces automatizácie bude digitálny, je najefektívnejším riešením prenechat digitalizáciu (teda v podstate zadanie) vstupných informácií priamo účastníkom sporu. ${ }^{93}$

Prijatie takéhoto menej konzervatívneho pohladu na automatizáciu a jej dopad na súdny proces však zrejme nebude mat výhradne pozitívne stránky a je možné, že do práva na prístup k súdu prinesie nové prekážky, ktoré v súčasnom „analógovom“ súdnictve neexistujú. Bežnou námietkou proti zavádzaniu ODR je „digitálne vylúčenie“, teda fakt, že nakol’ko si ODR vyžaduje určitú mieru digitálnych zručností ako aj prístup k internetu a patričnej technike, niektorým jedincom môže byt z týchto dôvodov staažený či odopretý prístup k súdu. ${ }^{94}$

Susskind v tomto ohl'ade prináša niekol'ko možných riešení na zníženie negatívneho dopadu na takto vylúčené osoby. Jedným z nich je paralelné zachovanie pôvodného „analógového“ procesu a tým druhým je zriadenie určitej asistenčnej služby, niečo ako kontaktné miesto pre l'udí, ktorí sami nie sú schopní alebo nemajú možnost̉ takéhoto prístupu k súdu. ${ }^{95}$

Je jasné, že zavádzanie takejto služby, prípadne paralelné udržiavanie dvoch systémov, analógového aj digitálneho, znižuje celkovú efektivitu tohto systému, čo by mala byt jeho hlavná výhoda a do určitej miery naspät vracia problém zbytočnej komplexnosti systému, čo bol problém, ktorý nás na túto stopu priviedol v prvom rade. ${ }^{96}$

Skôr, než budeme hladat’ možnost̉ začlenenia „digitálne vylúčených“ jedincov do takéhoto systému, je na mieste si položit otázku, či to vôbec je problém a ako vel'ký. Napokon v súčasnosti už sú niektoré verejnoprávne

93 K výhodám e-filingu a „paperless trials“ $\mathrm{z}$ pohladu sudcov a súdnej sústavy pozri napríklad: Briggs, M. On the cusp of a civil litigation [online]. Harbour Litigation Funding [cit. 18.12.2020]. https://www.harbourlitigationfunding.com/wp-content/uploads/2016/10/ The-speech-On-the-cusp-of-a-civil-revolution.pdf

94 Susskind, R. Online courts and the future of justice. Oxford: Oxford University Press, 2019, s. $215-221$.

95 Ibid.

96 Kanadský ODR Civil Resolution Tribunal napríklad rozoznáva inštitút „pomocníka“, čo je osoba odlišná od právneho zástupcu a jej úlohou môže byt mimo iné napríklad práve pomoc s vypĺňaním online formulárov. https://civilresolutionbc.ca/tribunal-process/starting-a-dispute/helpers-representation/ 
úkony, ktoré je možné konat výhradne digitálne, dokonca aj niektorá komunikácia so súdmi. ${ }^{97}$

Zdá sa, že digitálna gramotnost nie je až taká problematická v celkovej populácii. Tomu napokon nasvedčujú aj štatistiky, kedy podla dát získaných v rámci projektu „Europe 2020 “ je až $87 \%$ občanov pravidelným užívatel’om internetu a má prístup $\mathrm{k}$ jeho infraštruktúre. ${ }^{98}$ Tieto údaje boli jednako zozbierané pred 10 rokmi a hlavne na začiatku projektu, ktorého ciel'om bolo zvýšit digitálnu gramotnost v Európe. Je na mieste sa domnievat', že miera gramotnosti ako aj prístupu k potrebnej infraštruktúre sa odvtedy výrazne zvýšila aj s ohl’adom na mieru digitalizácie na pracoviskách ako aj príchodu generácie „digital natives“, či trendu rastu digitálnej gramotnosti. $^{99}$

Aj ked' je určite odporúčané tento vývoj d’alej sledovat', s ohl’adom na jeho trendy ako aj na súčasné požiadavky výhradne elektronickej komunikácie s niektorými štátnymi orgánmi, je na mieste sa domnievat, že digitálna gramotnost' do budúcna nebude predstavovat prekážku prístupu k súdu $\mathrm{v}$ rozhodnej miere.

Ďalšou spomínanou prekážkou je dížka konania. V tomto bode odkazujem čitatel’a na predchádzajúcu čast̉ tejto práce. Ďalej spomínané prekážky by sa dali označit hromadne ako procesné a patria sem aktívna legitimácia, premlčacie lehoty, príslušnost̉ súdov alebo požiadavky na zastúpenie. Všetky tieto problémy sú výhradnou otázkou procesného práva, podla ktorého by sa riadil aj automatizovaný proces, preto nie je dôvod sa

97 Príkladom môže byt komunikácie s Obchodným registrom Slovenskej republiky, voči ktorému môže byt podanie učinené výhradne elektronicky, bez ohl’adu na podávajúci subjekt - teda napríklad aj pri prvozápise.

98 Axess. Acquisition of Key Competences for Economic and Social Sustainability. Štrasburg: Erasmus + , 2017. http://www.axesslearning.eu/docs/AXESS-IO2-Snapshot-EU.docx

99 Výstup spomínaného projektu Europe 2020 v čase písania tejto práce nebol spracovaný, avšak sú $\mathrm{k}$ dispozícii iné aktuálnejšie štatistiky. Podla štatistiky Ministerstva školstva SR, ktoré si ju nechalo vypracovat's ohl’adom na uzavretie škôl pre pandemickú situáciu má v súčasnosti k internetu a potrebnej technike prístup viac ako 97\% žiakov. Vid' Ministerstvo školstva Slovenskej republiky. Možnosti dištančného vzdelávania pre školy [online]. MinEdu [cit. 18.12.2020]. https://www.minedu.sk/moznosti-distancneho-vzdelavania-preskoly/ 
domnievat, že by im bol na škodu a nie je predmetom tejto práce bližšie rozoberat inováciu výhradne ležiacu v zmenách procesných pravidiel.

Ďalšou vel'kou skupinou prekážok boli prekážky ekonomické, čiže otázky súvisiace so súdnymi poplatkami a nákladmi na konanie ako takými. Rôzne poplatky za súdne konanie môžeme nájst’ azda vo všetkých členských krajinách a na obecnej úrovni ich zavedenie podla ESL’P nie je problematické. ${ }^{100}$

Schéma poplatkov, ktoré je nám známe z Českej republiky, teda $5 \%$ žalovanej čiastky, s horným aj spodným ohraničením výšky takto stanoveného poplatku ${ }^{101}$ a fixným stanovením poplatkov pri žalobách, ktoré sa nedajú ocenit, je podla Molka konformná s prístupom ESL’P k tejto problematike, čo dovodzuje najmä $\mathrm{z}$ absencie rozsudkov, resp. žalôb voči Českej republike pred ESL'P v týchto otázkach. ${ }^{102}$ Právny poriadok Českej republiky tiež rozoznáva komplexnú schému oslobodenia od súdnych poplatkov, čo rozhodne prispieva konformnosti takéhoto nastavenia. ${ }^{103}$

Aby bolo stanovenie poplatkovej povinnosti vôbec prípustné, tak ako pri akomkol’vek inom obmedzení, treba skúmat' jeho proporcionalitu, a teda treba skúmat', aký zámer je stanovením tohto obmedzenia sledovaný. Pospíšil v komentári k článku 36 uvádza, že ciel’om zavedenia súdnych poplatkov je ochrana súdnej sústavy pred jej pretažením a aby právo na súdnu ochranu nebolo jednotlivcami zneužívané a aby nebolo uplatňovanie tohto

${ }^{100}$ García Manibardo proti Španielsku, rozsudok Európskeho súdu pre l'udské práva, 15.02.2000 č. st̉ažnosti 38695/97 - ESL’P takúto situáciu vníma ako problematickú až v momente ked' by nezaplatenie viedlo k odmietnutiu spravodlivosti a zdôrazňuje, že štáty by mali poskytovat pomoc, napríklad $\mathrm{v}$ podobe odpustenia poplatku, či finančnej asistencie a podobne ak je to potrebné. V zásade rovnako potom ESL’P pristupuje aj ku skladaniu istín, či akéhokolvvek finančného podmienenia prístupu k súdu, ak je stanovený za vyššie uvedených podmienok a zároveň jeho výška nie je neprimeraná ako tomu bolo v prípade Kreuz proti Polsku, kedy suma ktorú mal pán Kreuz pred začatím súdneho konania zaplatit’ predstavovala jeho ročný plat. Vid’ Kreuz proti Pol’sku, rozsudok Európskeho súdu pre l’udské práva, 19.06.2001 č. stažnosti 28249/95.

${ }^{101}$ V rozsudku Urbanek proti Rakúsku, rozsudok Európskeho súdu pre ludské práva, 09.12.2010 č. stažnosti 35123/05 ESL’P privolilo, že takáto forma stanovovania súdnych poplatkov v majetkových sporoch nie je na prekážku práva na prístup k súdu.

${ }^{102}$ Molek. Právo na spravedlivý proces. s. 120.

${ }^{103}$ K oslobodeniu od súdnych poplatkov pozri bližšie § 11 - § 14 zákona č. 549/1991 Sb., zákon České národní rady o soudních poplatcích. 
práva svojvol’né, či obštrukčné. Ďalej uvádza, že takéto obmedzenie prístupu k súdu poplatkovou povinnostou je prípustné, ak sleduje niektorý z týchto ciel’ov a jej výška je primeraná tomu, čo je pre účastníka v danom procese v stávke. ${ }^{104}$

V zásade identický prístup $\mathrm{k}$ tomuto problému má podla Kmeca aj ESL’P. Ako protihodnotu, ktorú treba posudzovat naproti obmedzeniu prístupu k súdu poplatkovou povinnostou, uvádza Kmec všeobecný záujem na riadnom výkone spravodlivosti. ${ }^{105}$ Ďalej tiež uvádza, že tento poplatok nemožno vnímat ako príjem štátu, či súdu, nakol'ko jeho účelom má byt nanajvýš pokrytie nákladov. $\mathrm{V}$ rámci tých je potom prípustné požadovat zálohu na rôzne súdne úkony, ako napríklad náklady na súdneho znalca a podobne. ${ }^{106}$ Ďalšou funkciou poplatku, ktorá ospravedlňuje jeho percentuálne vymeriavanie u peňažných nárokov, je určitá moderačná funkcia, ktorá by takýmto spôsobom vymeriavania mala zabránit tomu, aby si žalujúci nárokoval nerealistické a premrštené čiastky. K efektívnosti tejto funkcie však Kmec pristupuje skôr skepticky. ${ }^{107}$

Na základe vyššie uvedených pohladov zo strany ústavného súdu a ESL'P, respektíve pohl’adu českého právneho poriadku a Dohovoru, je možné uzavriet', že ekonomické prekážky, v podobe zavedenia súdneho poplatku nie sú nezlučitel’né s právom na prístup $\mathrm{k}$ súdu, za podmienky, že výška poplatku je stanovená primerane a zároveň existuje možnosť oslobodenia v relevantných situáciách.

Takéto opatrenia majú zároveň chránit d’alší relevantný záujem, ktorým je efektívna súdna sústava, potažmo potom jej nezahlcovanie neopodstatnenými nárokmi. To nás privádza $\mathrm{k}$ záveru, že súdne poplatky sú prekážkou prístupu $\mathrm{k}$ súdu a tie ideálne nechceme, ak nie sú opodstatnené inou dôležitou hodnotu, v tomto prípade efektívnostou súdnej sústavy. Teda ak by sa nám podarilo zvýšit efektívnost súdnej sústavy, mohli by sme upustit od tejto prekážky a rozšírił tak prístup k súdu.

\footnotetext{
${ }^{104}$ Wagnerová et al. Listina základních práv a svobod. Komentář. s. 731.

${ }^{105} \mathrm{Kmec}$ et al. Evropská úmluva o lidských právech: komentář, s. 635.

${ }^{106}$ Ibid., s. 635-637.

107 Ibid., s. 636-637.
} 
Môžeme odôvodnene predpokladat', že zavádzanie automatizácie do súdneho procesu bude viest' k jeho zefektívneniu, ako už bolo z časti naznačené aj v predchádzajúcej časti tejto práce. Zefektívnenie by malo znížit aj náklady na konanie a tiež umožnit procesovanie väčšieho množstva prípadov, čo opät ul'ahčuje a zefektívňuje konanie. Takéto zníženie nákladov a zefektívnenie procesu by potom mohlo viest' $\mathrm{k}$ širšiemu poňatiu práva na prístup k súdu. ${ }^{108}$

Samozrejme, že automatizácia nepovedie k úplnému zaniknutiu všetkých poplatkov v rámci súdneho konania. Poplatky, ktoré majú fungovat ako záloha na náklady spojené s d’alšími súdnymi úkonmi, akými sú napríklad vypracovanie znaleckých posudkov, či záloha na náklady úspešnej strany sporu, týmto procesom nebudú nijak ovplyvnené, a teda z tohto dôvodu by k ich zmene nemalo dôjst'. Avšak s ohl'adom na konštantnú judikatúru ESL'P tieto poplatky nie sú problematické, a teda ich neodstránenie automatizáciou súdneho rozhodovania tiež nemožno považovat̉ za prekážku.

Konečne, existencia súdnych poplatkov môže byt̉ ospravedlnená ešte aj ich moderačnou funkciou pri peňažných nárokoch. Okrem faktu, že efektívnost̉ takéhoto nástroja je spochybňovaná, aj odrádzanie žalobcov od neopodstatnených nárokov je v konečnom dôsledku prípustné, pretože má zabránit pretažovaniu súdov. Protihodnota tohto obmedzenia je rovnaká ako v predchádzajúcom odstavci a ak by sa podarilo súdne procesy automatizáciou zefektívnit', je na mieste uvažovat’ o odôvodnenosti ponechania poplatkov $\mathrm{z}$ takéhoto dôvodu, respektíve $\mathrm{v}$ takej miere, $\mathrm{v}$ akej sú stanovované teraz.

V tejto časti sme sa už okrajovo venovali prekážkam prístupu k súdu, ako je napríklad obmedzenie lehoty na podanie opravného prostriedku a podobne, ktoré súvisia okrem iného s právnou istotou protistrany sporu a ktoré sú dané procesnými pravidlami. V zásade - $\mathrm{k}$ ich zmene by nemalo dôjst’ z dôvodu zavedenia automatizácie. Podobnou skupinou prekážok prístupu k súdu je aj posledná skupina sociálnych a kultúrnych problémov, čiže problémov zo skupiny prekážok, ktoré nie sú založené zákonom.

${ }^{108}$ Ulenaers, J. The Impact of Artificial Intelligence on the Right to a Fair Trial: Towards a Robot Judge? Asian Journal of Law \& Economics. 2020, č. 2. 
Podl’a výskumu OECD sú tieto problémy spôsobené najmä sociálnym znevýhodnením niektorých jedincov, ktoré vytvárajú nerovné možnosti prístupu k súdu a právnej pomoci a zároveň ich vrhajú do bludného kruhu rôznych „bagatel’ných“ sporov, ktoré často ich sociálne postavenie len d’alej znevýhodňujú. Vel’mi úzko s takouto prekážkou súvisia aj kultúrne problémy, ktoré panel OECD demonštruje na nemožnosti dovolania sa prístupu k súdu l’ud’mi bez domova.

Aj ked' sa môže zdat', že tieto prekážky sú skôr otázkou sociálnej politiky krajiny, akou nepochybne do vel'kej miery aj sú, nie je možné bez d’alšieho vylúčit dopad automatizácie do tejto oblasti. Otázky sociologických aspektov automatizácie výkonu súdnictva, či vôbec to, akým spôsobom bude takýto proces vnímaný širokou verejnostou, sú rozhodne zaujímavé a dôležité, no svojím rozsahom ako aj metodológiou sú nad rámec tohto článku. V tomto bode však nie je úplne nemiestne na základe predchádzajúceho pojednania vyslovit odhad, že automatizácia, ktorej zavedenie by malo priniest' zefektívnenie súdnej sústavy, by mohla takýmto spôsobom priniest’ pozitívny dopad aj na problémy sociálnych prekážok prístupu k spravodlivosti.

Technologický pokrok v súdnictve vo všeobecnosti už v súčasnosti ul'ahčuje prístup k súdu, respektíve prístup k právnym informáciám širokej verejnosti, a tak prispieva k určitej „demokratizácii“ justície. ${ }^{109}$ I ked’ je narastanie dostupnosti správnym krokom k tomu, aby sa dostalo k právnej pomoci väčšie množstvo l’udí, ani zd’aleka to nie je odpoved' na sociálne prekážky prístupu k súdu, nakol'ko práve sociálne vylúčené skupiny budú mat’ zrejme k takto prístupným informáciám nad’alej stažený prístup.

Automatizáciu súdneho rozhodovania nemožno považovat za riešenie alebo odstránenie sociálnych prekážok, ktoré sú skôr problémom sociálnej politiky štátu. Na druhej strane ani nie je dôvod sa domnievat, že by auto-

\footnotetext{
${ }^{109}$ Ibrahim, M. Justice for all: how technology is promoting public access [online]. Raconteur. 30. 11. 2018 [cit 23. 12. 2020]. https://www.raconteur.net/legal/technology-public-access-justice/
} 
matizácia nejakým spôsobom zhoršila prístup k spravodlivosti v tomto ohl'ade. $^{110}$

Právo na prístup k súdu je samo o sebe vel'mi komplexným aspektom práva na spravodlivý proces, ktorého podrobné posúdenie vyžaduje aj iné, než len výhradne právne analýzy, nakol'ko k jeho obmedzeniam neprichádza len právne, ale aj fakticky. Pre právo na spravodlivý proces je práve tento aspekt absolútne elementárny, nakol'ko až po začatí procesu môžeme diskutovat o jeho spravodlivosti. Aj s ohl'adom na jeho základný význam je nutné početné (zákonné) obmedzenia tohto práva, ktoré v súčasnosti existujú, nutné vnímat vo svetle ich ciel'a, ktorým rozhodne nie je obmedzit’ prístup jedinca k spravodlivosti, ale zabezpečit efektívne fungovanie (nepretaženej) súdnej sústavy. Pri takomto vnímaní obmedzení môžeme dôjsţ k záveru, že zefektívnením súdneho procesu by bolo možné vel'kú čast’ zákonných obmedzení prístupu odstránit. Samozrejme stále existujú prekážky prístupu k súdu, ktoré zefektívnením, respektíve automatizáciou súdneho procesu nebudú zasiahnuté, a tak by obmedzenia $\mathrm{v}$ takejto forme pretrvali aj nad’alej. Je to však dôvod neexistencie tohto zásahu automatizácie do týchto práv, ktorá nás môže viest’ k záveru, že menované obmedzenia ňou nebudú nijak zhoršené, či negatívne zasiahnuté. Preto ak pripustíme, že súčasné pravidlá obmedzovania prístupu k súdu sú zlučitel’né s právom na spravodlivý proces, nie je dôvod sa domnievat', že automatizácia súdneho rozhodovania by, aspoň v tomto ohlade práva na spravodlivý proces, s ním zlučitel'ná nebola.

\subsection{PRÁVO NA NESTRANNÝ A NEZÁVISLÝ SÚD}

Ak sa nám podarilo využit práva na prístup $\mathrm{k}$ súdu a tiež ho zahájit včas, d’alším aspektom, ktorý by nás zrejme zaujímal, je fakt, že tento proces bude „férový“ žiadna zo strán nebude požívat výhodu na strane osoby sudcu. Toto je skutočnost', ktorú by nám mali zaručit požiadavky na nestranný a nezávislý súd, ktoré tvoria doktrinálnu súčast̉ práva na spravodlivý proces.

\footnotetext{
${ }^{110} \mathrm{~V}$ tomto bode odkazujem čitatel'a spät k časti o digitálnej gramotnosti v tejto kapitole.
} 
Nezávislost̉ a nestrannost sú funkčne dva rozdielne problémy, výsledok nezaistenia ich prítomnosti v súdnom rozhodovaní vedie však k rovnakému skresleniu spravodlivosti, preto sú často spájané. $\mathrm{Z}$ toho dôvodu bude o nich $\mathrm{v}$ tejto práci pojednané $\mathrm{v}$ nasledujúcej časti. ${ }^{111}$

Okrem prieniku týchto dvoch (pod)aspektov je v tejto oblasti výrazný technologický prienik, nakolko problém zaujatosti ${ }^{112}$ je vel'mi často riešený aj pri algoritmickom dizajne . Riešenie právneho problému zaujatosti si vyžaduje aspoň základné pochopenie problému zaujatosti v algoritmickom dizajne, preto sa v skratke budeme venovat aj technickej stránke tohto problému. S ohl'adom na komplexnoste tohto problému, ktorý tvorí takmer až samostatné pole výskumu umelej inteligencie, sa táto práca obmedzí len na vel’mi povrchný opis tejto problematiky, z pohl’adu autora dostačujúcej pre právne posúdenie. ${ }^{113}$

Nezávislost̉ súdu môže byt vnímaná z funkčného či organizačného pohl'adu na súdnu sústavu, často je preto označovaná aj ako nezávislost z objektívneho hladiska. ${ }^{114} \mathrm{Na}$ úplne najvyššej úrovni by mala byt zabezpečená nezávisloste súdu, resp. sudcovského rozhodovania od ingerencií zo strany zvyšných dvoch zložiek štátnej moci. Ohrozenie nezávislosti však nepredstavuje len „štát“, resp. štátne orgány, ale tiež iné externé vplyvy tretích osôb, akými môžu byt napríklad médiá. V neposlednom rade môže byt' nezávislost' narušená aj osobami zúčastnenými na prebiehajúcom spore, či inými sudcami daného súdu. ${ }^{115,116}$

ESL'P vo veci Findlay proti Spojenému královstvu ${ }^{117}$ ustanovil niekol'ko kritérií, na základe ktorých sa posudzuje nezávislost̉ súdu. Pre posúdenie nezávislosti je na základe týchto kritérií potrebné zvážit spôsob menovania a výberu sudcov a dížku ich mandátu (prípadne možnosti jeho predčasného

\footnotetext{
${ }^{111} \mathrm{~K}$ ich takmer výhradne společnému posudzovaniu zvykne pristupovat aj ESL’P, vid'. Leanza, Pridal. The Right to a Fair Trial: Article 6 of the European Convention on Human Rights, s. 128.

${ }^{112}$ Zaujatost̃ v súdnom rozhodovaní je termínom opisujúcim nestrannost̉ súdu a bude v tejto práci používané zamenitelne.

${ }^{113}$ Táto stat z časti vychádza z predchádzajúcej autorovej práce na tému „Automatizácia rozhodovacích systémov“, ktorá bola spracovaná v rámci Študentskej vedeckej odbornej činnosti v roku 2020.

${ }^{114} \mathrm{Kmec}$ et al. Evropská úmluva o lidských právech: komentár̆, s. 670.

${ }^{115}$ Ibid.
} 
ukončenia), záruky voči externému nátlaku a skutočnost’, či sa súd navonok ako nezávislý javí.

Podmienky nezávislosti stanovuje ESL’P aj v samotnej definícii pojmu „súd“. Medzi jeho znaky totižto musí patrit nezávislost’ od výkonnej moci a strán sporu, dížka sudcovského mandátu, procesné záruky nezávislosti a v neposlednom rade by sa mal súd javit’ ako nezávislý aj navonok. Posledným znakom nezávislého súdneho telesa by mala byt’ kapacita vydávat’ záväzné rozhodnutia, ktoré nemôžu byt’ zmenené, či ich výkon odmietnutý inak, než opät súdnou cestou. ${ }^{118}$

Asi nie prekvapivo je v kontexte článku 36 nárok na nezávislý súd nielen rovnako vyžadovaný, ale tiež v zásade obdobne vykladaný. Podla Pospíšila má táto záruka za úlohu v prvom rade najmä zabezpečit dodržanie del’by moci v štáte, čiže izoláciu súdnej moci a súdnictva od nežiadúcich vplyvov zo strany exekutívnej a legislatívnej moci. ${ }^{119}$ Pospíšil však identifikuje aj konkrétne scenáre, v ktorých by mohlo dochádzat k vonkajšiemu ovplyvňovaniu rozhodovania súdov. Podobne ako pri analýze ESL’P by malo íst' o spôsob menovania, ktorému nie je na prekážku, že je vykonávané výkonnou zložkou moci, ak existujú adekvátne záruky, ako napríklad presné stanovenie takéhoto procesu a počet menovaných pozícií. To analogicky platí aj o súdnych funkcionároch. Ďalším potencionálne problematickým aspektom môže byt časové obdobie, na ktoré je sudca menovaný do funkcie. Ústavný súd sa vyslovil, že časové obmedzenie je vo všeobecnosti prípustné, musí však byt kompenzované o to komplikovanejšími podmienkami na odvolanie. ${ }^{120}$

${ }^{116}$ Závislostou na tretích osobách môže byt napríklad aj taký prípad, kedy sa súd dožiada iného než súdneho telesa poskytnutia záväzného stanoviska, ako napríklad inštrukcie Ministerstva zahraničných vecí $\mathrm{k}$ výkladu záväznej medzinárodnej dohody. $\mathrm{V}$ takom prípade už totiž súd nemožno považovat za nezávislý na moci výkonnej. Vid’ Beaumartin proti Francúzsku, rozsudok Európskeho súdu pre luudské práva, 24.11.1994 č. stažnosti $15287 / 89$.

117 Findlay proti Spojenému král'ovstvu, rozsudok Európskeho súdu pre luudské práva, 25.02.1997 č. stažnosti 22107/93.

${ }^{118}$ Leanza, Pridal. The Right to a Fair Trial: Article 6 of the European Convention on Human Rights, s. 129-132.

119 Wagnerová et al. Listina základních práv a svobod. Komentář., s. 737.

${ }^{120}$ Ibid., s. 738. 
Ďalšou potencionálnou prekážkou sudcovskej nezávislosti, na ktorú Pospíšil upozorňuje obzvlášt v kontexte českého súdnictva, je otázka materiálneho zabezpečenia. Platové pomery by $\mathrm{v}$ tomto ohlade mali byt rovnako relatívne nezávislé na zvyšných zložkách moci, malo by sa preto jednat o stabilnú veličinu, ktorá nemôže byt svojvol’ne menená zo strany zákonodarcu ako akási nepriama forma úplatkárstva, či „odmien za dobré rozhodovanie“. ${ }^{121,122}$

Ako posledné kritérium uvádza Pospíšil v komentári nezávislost od vonkajších vplyvov, teda bud'to od priamych inštrukcií iných orgánov, s výnimkou nadradenej súdnej inštancie, alebo nepriamo prostredníctvom rôznych verejných vyjadrení politikov ako to $\mathrm{v}$ Čechách malo byt̉ napríklad $\mathrm{v}$ otázkach reštitúcií šlachtického majetku. ${ }^{123}$

Okrem Listiny a v nej zakotveného práva na spravodlivý proces, pod ktorým sa nachádza požiadavka na nezávislý súd, je táto požiadavka reflektovaná $\mathrm{v}$ českom kontexte ešte aj $\mathrm{v}$ článku 81 Ústavy, ktorý ustanovuje požiadavku na inštitucionálnu nezávislost̉ súdov a v článku 82, ktorý zase odráža požiadavku na nezávislost’ rozhodovania na „nižšej“ úrovni sudcov. ${ }^{124}$ Na zákonnej úrovni sú potom tieto dva články rozvedené v Zákone o súdoch a sudcoch $\quad \mathrm{v} \S 79$ a z časti aj $\mathrm{v}$ nasledujúcich paragrafoch. ${ }^{125}$ Ústavný súd tieto dva články vykladá vo vel’mi podobnom duchu ako bolo načrtnuté vyššie. Malo by sa jednat o záruku, že súdy (a sudcovia) môžu svoje rozhodnutia opierat výhradne o zistené fakty a ich právnu stránku a vlastný názor bez toho, aby mali akékol’vek záväzky voči

\footnotetext{
${ }^{121}$ Ibid.

${ }^{122}$ Otázka platov je relevantná pre prostredie českej justície, nakolko sa s ňou opakovane vysporiadaval Ústavný súd, no ani zd’aleka sa nejedná o jedinú možnost̉ zasahovania do nezávislosti prostredníctvom hmotného zabezpečenia. Nechválne známym bude zrejme aj českému čitatelovi prípad Štefana Harabina, ktorý ako predseda Najvyššieho súd SR „trestal“ nepohodlných sudcov ich presúvaním do kancelárií v podkroví, bez klimatizácie a iného technického zázemia, či do vzdialenejších budov, alebo odnímaním služobných motorových vozidiel a pod. K tomu vid' napr. Hanus, J. M., Martin. Harabinokracia [online]. .týždeň iný pohlad na spoločnost'. 26. 10. 2009 [cit 6. 1. 2021]. https://www.tyzden.sk/casopis/ 5614/harabinokracia/

${ }^{123}$ Wagnerová et al. Listina základních práv a svobod. Komentár̆., s. 739.

124 Článok 81 a 82 zákona č. 1/1993 Sb., Ústava České republiky.

${ }^{125} \S 79$ a násl. zákona č. 6/2020 Sb., o soudech a soudcích.
} 
stranám sporu či iným štátnym orgánom, alebo aby ich rozhodnutie podliehalo kontrole iného orgánu. ${ }^{126,127}$

Do vel'kej miery sa v tomto prípade jedná o nejakú formu inštitucionálneho ovplyvňovania. Tento problém je možné relatívne odstránit zavedením vhodných inštitucionálnych záruk, napokon tak, ako to požaduje aj ESL'P vo svojej judikatúre. Druhou vel'kou zložkou, ktorá sa do určitej miery prekrýva, je ovplyvnenie spôsobené „l'udským“ faktorom, ako je práve „kupovanie“ si sudcov prostredníctvom rôzneho materiálneho zabezpečenia. V prostredí automatizovaného rozhodovania môžeme tieto obavy vylúčit. Jediná obava o nezávislost rozhodovacieho systému by mohla nastat v podobe ingerencie zvyšných zložiek štátnej moci či súkromného aktéra, pri dizajne rozhodovacieho algoritmu, alebo systému ako takého. K takému zásahu môže dôjsț v zásade iba vo fáze tvorby systému, či jeho následnej úpravy a v podstate môže byt „jednoducho“ odstránená transparentnostou takéhoto systému a jeho otvorením širokej verejnosti. O potrebe transparentnosti rozhodovacieho systému bude pojednané nižšie.

Jediná námietka, ktorá by sa mohla pri zavádzaní automatizácie objavit, sa vyskytuje pri systémoch fungujúcich ako tzv. ,judge supporting systems“ . V takomto scenári môžeme vychádzat z už reálne existujúcej skúsenosti sudcov v Spojených štátoch Amerických so systémom COMPAS, ktorý sa používa na predikciu šance recidívy u prepúštaných väzňov. Sudcovia, ktorí majú tento systém $\mathrm{k}$ dispozícii, môžu totiž jednako vnímat nátlak zo strany širokej verejnosti, ako aj iných súdnych inštancií $\mathrm{k}$ tomu tento systém nielen využívat', ale s ohl'adom na všeobecnú tendenciu l’udí vkladat väčšiu dôveru do strojových rozhodnutí ${ }^{128}$ sa môžu cítit viazaní predikciou tohto systému. ${ }^{129} \mathrm{Aj}$ ked’ sa tento článok sústredí primárne na komplexnú algoritmizáciu sudcovského rozhodovania, je na mieste adresovat aj túto námi-

\footnotetext{
${ }^{126}$ Do poznámky pod čiarou je vhodné uviest zaujímavý postreh Ústavného súdu, že táto nezávislost̉ je, a musí byt', relatívna, nakol'ko súd vždy musí byt viazaný platným právom. To však neznamená, žeby bol súd podriadený zákonodarnej moci.

${ }^{127}$ Nález Ústavného súdu zo dňa 28. apríla 2005, sp. zn. Pl. ÚS 60/04.

${ }^{128}$ Citron, D. K. Technological Due Process. Washington University Law Review. 2008, č. 6, s. 1249-1313.

${ }^{129}$ Ulenaers. The Impact of Artificial Intelligence on the Right to a Fair Trial, s. 23.
} 
etku, nakol'ko je možné si predstavit systém, ktorý by na vyšších inštanciách či pri tzv. „hard cases“ používal kombinácie týchto dvoch systémov. $\mathrm{Z}$ autorovho pohl'adu je možné do vel'kej miery zníziit takýto negatívny dopad „slepého“ preberania strojových odporúčaní povinnostou sudcov riadne svoje rozhodnutia odôvodnit, a to tak, aby nemohla vzniknút obava, že $\mathrm{k}$ takémuto negatívnemu javu dochádza. $\mathrm{V}$ súvislosti so systémom COMPAS sa, okrem iného, touto otázkou zaoberal aj Najvyšší súd štátu Wisconsin, v prípade State v. Loomis. V tomto prípade sa súd zaoberal otázkou individualizácie trestu pri využívaní automatizovaných systémov a jedným $\mathrm{z}$ argumentov súdu bola skutočnost', že sa nejedná o konečné rozhodnutie a že nemožno upriet schopnost̉ sudcov zvážit takto vyprodukované odporúčanie a na základe vlastného presvedčenia a odbornosti s ním d’alej nakladat. Najvyšší súd teda v zásade popiera, že by sudca „slepo“ preberal strojové rozhodnutia pri výkone svojej funkcie. ${ }^{130}$

Európska etická charta využívania umelej inteligencie v súdnictve vypracovaná Európskou komisiou pre efektívnu spravodlivost vidí podobný problém takéhoto „slepého“ preberania záverov automatizovaných systémov. Nemalo by k nemu však dochádzat zo spomínanej prirodzenej tendencie skôr verit strojovým rozhodovaniam, ale $\mathrm{z}$ obavy sudcov, že v prípade neprebratia takéhoto rozhodnutia bude ich rozhodovacia činnost viac kontrolovaná dozornými orgánmi a tiež z obavy o zodpovednost', či už civilnú alebo vo forme znovu nezvolenia u verejnostou volených sudcov, v prípadoch chybného vlastného rozhodnutia. ${ }^{131}$ Takáto obava určite predstavuje vážny zásah do nezávislosti súdneho rozhodovania a akokolvek je vhodné naň upozornit a venovat sa mu počas prípadnej implementácie, určite sa nejedná o absolútnu či neodstránitel’nú prekážku. Zmiernenie dopadu tohto problému je v zásade otázka nastavenia (disciplinárnej) zodpovednosti sudcov, ako aj spôsobu ich menovania a dížky funkcie. Tu je určite na mieste poznamenat, že ak existuje takáto obava, teda o existenciu nátlaku na sud-

\footnotetext{
${ }^{130}$ State v. Loomis [online]. [cit 1. 11. 2020]. https://harvardlawreview.org/2017/03/state-vloomis/

${ }^{131}$ CEPEJ. European ethical Charter on the use of Artificial Intelligence in judicial systems and their environment [online]. Council of Europe. [cit 23.12.2020]. s. 57. https://rm.coe.int/ ethical-charter-en-for-publication-4-december-2018/16808f699c
} 
cov k využívaniu eventuálnych expertných systémov, tak potom musí byt takýto systém chybne nastavený už od prvopočiatku a sudcovia v ňom nemajú záruku dostatočnej nezávislosti bez ohl’adu na používanie nových technológií. Napokon, podobne to vidí aj vyššie spomínaná správa Komisie, ktorá upozorňuje na to, že tieto problémy budú o to výraznejšie, čím horší je prvotný stav justičného systému v tej ktorej krajine. ${ }^{132}$

Druhým aspektom, ktorý musíme $\mathrm{v}$ tejto časti rovnako konfrontovat' s automatizáciou, je už vyššie spomínaný pridružený problém práva na nezaujatý súd. ${ }^{133}$ Tento aspekt už nie je systémovým, no skôr individuálnym problémom, ktorý sa neviaže na sudcovskú sústavu, ale osobu konkrétneho sudcu či sudcov. Prípadne, ako to zhodnotil Šimíček v komentári k Ústave, nezávislost’ je predpokladom funkčným, kdežto nestrannost̉ je predpokladom osobným a je otázkou svedomia konkrétneho sudcu. ${ }^{134}$

ESL’P vníma nestrannost' ako aspekt skladajúci sa z dvoch zložiek - subjektívnej a objektívnej. K zaručeniu nestrannosti musia byt zabezpečené obe zložky, ako tá subjektívna, teda že sudca $v$ danom prípade nemá žiadne osobné záujmy, predsudky či sympatie voči niektorej zo strán sporu, tak aj tá objektívna, ktorá je vo svojej podstate vel’mi podobná ako jeden z nárokov na nezávislý súd v predchádzajúcej časti - teda sudca by mal svojím vystupovaním nepodnecovat', či dokonca odstránit pochybnosti o svojej zaujatosti. Inak povedané, nestačí, že je sudca nezaujatý (subjektívny test), musí sa ako nezaujatý aj javit' (objektívny test). ${ }^{135}$

S ohl'adom na prvú požiadavku, subjektívnu nezávislost', Harris poukazuje na to, že nestrannost’ sudcu sa predpokladá a jedná sa o vyvrátitel’nú domnienku. K vyvráteniu tejto domnienky je potrebné existenciu zaujatosti

\footnotetext{
${ }^{132}$ Ibid.

${ }^{133}$ Nestrannost’ a nezaujatost’ sú synonymá a ako také budú v tejto práci používané zamenitel’ne, čo reflektuje aj súčasná odborná literatúra, ktorá používa oba termíny na označenie tohto javu. Molek uvádza, že nestrannost̉ je koncept zahŕňajúci absenciu zaujatosti a predsudkov. V kontexte tejto práce bude však zaujatost̉ zahŕn̆at aj predsudky. Vid'. Molek. Právo na spravedlivý proces. s. 169.

134 Šimíček, V. In: Bahýlová, L. a kol. Ústava české republiky - komentář. Praha: Linde, 2010. s. 982

${ }^{135}$ Hauschildt proti Holandsku, rozsudok Európskeho súdu pre l’udské práva, 24.05.1989 č. stažnosti 10486/83, odstavec 46.
} 
fakticky preukázat’ stranou, ktorá jej existenciu namieta. Ako však Harris poukazuje d’alej, nakol'ko sa jedná o „subjektívnu“ stránku, jej dokazovanie je vel’mi náročné a zavedenie nejakého testu, ako je to $\mathrm{v}$ mnohých iných otázkach práv vyplývajúcich z Dohovoru, je prakticky nemožné. ${ }^{136}$

Existuje ešte d’alšie možné delenie nezaujatosti, ktoré by aspoň z časti mohlo viest' k zavedeniu objektívneho testu, a to delenie na funkčnú a osobnú nezaujatost. ${ }^{137}$ Funkčná nezaujatost̉ rozširuje posudzovanie nezaujatosti na rolu sudcu v súdnom systéme, najmä s ohl'adom na jeho predchádzajúce funkcie a pôsobenie. Existenciu takejto funkčnej zaujatosti zistil ESL’P v prípade Werner proti Pol’sku, v ktorom insolvenčný správca, ktorý navrhol odstránenie likvidátora z pozície, bol členom senátu, ktorý mal o odstránení rozhodnút. V takomto prípade ESLP uznal, že sa jedná o (funkčne) zaujatého sudcu, z čoho možno poukázat na zaujímavý aspekt nároku na nezaujatost́. Konkrétne sa nemusí jednat iba o antipatiu voči jednej zo strán alebo predsudky sudcu, ale k jeho porušeniu dochádza vždy, ked’ sudca zahajuje spor s vopred utvoreným názorom. Nakol'ko ide o funkčné zhodnotenie predchádzajúceho pôsobenia danej osoby, jedná sa zrejme o jediný, objektívne ohodnotitel’ný aspekt tohto nároku.

Právo na nestranný súd je samozrejme zaručené jedincovi aj Listinou, a to ako právo na taký súd, ktorý je nezávislý a nezaujatý tak ako vo vztahu $\mathrm{k}$ stranám sporu, tak aj $\mathrm{k}$ jeho predmetu. ${ }^{138}$ Od ESL’P Ústavný súd prebral dvojité kritérium hodnotenia nezaujatosti ako zložky subjektívnej a zložky objektívnej. Dôvod takéhoto ponímania nezaujatosti bližšie Ústavný súd rozviedol v náleze I. ÚS 371/04, kde opisuje práve vyššie spomenutý problém s praktickou nemožnostou posudzovania subjektívnej zložky nezaujatosti, ako subjektívnej psychickej zložky sudcu, vylučujúcej objektívne preskúmanie vnútorného rozpoloženia sudcu. Takýto stav si preto vyžaduje rozšírenie tejto kategórie aj na zložku objektívnu vo forme vonkajšieho prejavu nestrannosti.

\footnotetext{
${ }^{136}$ Harris, O’Boyle, Warbrick. Law of the European Convention on Human Rights, s. 290-291.

137 Ibid.

${ }^{138}$ Wagnerová et al. Listina základních práv a svobod. Komentářr., s. 739.
} 
Zhodné stanovisko Ústavný súd zaujal aj s ohl'adom na del'bu nezaujatosti na funkčnú a osobnú, pričom sa vo vyššie spomínanom náleze vyjadril aj $\mathrm{k}$ problematike funkčnej nezaujatosti. V zásade pri jej posudzovaní treba zvažovat funkčnú závislost pozícií, ktoré by mali byt๋ v konflikte. ${ }^{139}$

Pospíšil si v komentári k Listine pri osobnej zložke nezaujatosti vypomáha odkazmi na judikatúru ESLP, môžeme teda vidiet’ blízku previazanost' týchto dvoch úrovní právnej záruky práva na spravodlivý proces čo do interpretácie tejto zložky. K osobnej zložke potom uvádza, že by sa pri jej posudzovaní mala skúmat osobná zainteresovanost’ sudcu na výsledku konania a to či už na základe jeho vzţahu k predmetu konania, účastníkom alebo ich zástupcom. ${ }^{140}$

Imperatív nezaujatosti sudcu je reflektovaný aj na zákonnej úrovni v jednotlivých procesných ustanoveniach ako napr. § 14 - 17 zákona č. 99/1963 Sb., občanský soudní řád, ktorý jednako stanoví (funkčné a osobné) dôvody, pre ktoré je možné daného sudcu považovat' za zaujatého a najmä v $§ 15$ sa snaží o „preklenutie“ problému dokazovania subjektívneho psychického stavu, ktorým je zaujatost', apelom na sudcu smerom k jeho vlastnému zhodnoteniu situácie a vylúčeniu sa $\mathrm{z}$ rozhodovania v danej veci, a podobne ako Šimíček v komentári k Ústave spomínanej úvodom, apeluje na svedomie jednotlivých sudcov. ${ }^{141}$

Vylúčenie zaujatého sudcu samozrejme nestojí výhradne na ňom a jeho svedomí, ale táto námietka podl’a vyššie citovaných zákonných ustanovení náleží aj účastníkom procesu. Táto možnost̉ podl’a Molka stojí hlavne na poučení účastníkov o personálnom zložení senátu pred zahájením konania, resp. $\mathrm{v}$ takom čase, ktorý umožňuje vznášat námietky zaujatosti. ${ }^{142,143}$ Takto sa dáva účastníkom možnost’ namietat̉ minimálne funkčnú zaujatost̉ sudcu.

139 Ibid., s. 740.

${ }^{140}$ Ibid., s. 741.

${ }^{141}$ Podobné nastavenie môžeme nájst̉ aj v iných procesných predpisoch, ako napríklad v § 14 ods. 4 zákona č. 500/2004 Sb., správní řád.

${ }^{142}$ Molek. Právo na spravedlivý proces, s. 171.

${ }^{143}$ Záverom úvodu tejto kapitoly potom Molek uvádza, že je to práve nezaujatost̉ súdu a sudcov, ktorá predstavuje povestnú „slepú“ justíciu, zobrazovanú s páskou cez oči. Ibid. 
Týmto pojednaním by sme po vzore predchádzajúcich častí mohli považovat súčasný stav tohto aspektu za vyčerpaný a mali by sme pristúpit $\mathrm{k}$ jeho konfrontácii s procesom automatizácie rozhodovania. Podobne ako tomu bolo $\mathrm{v}$ otázke prístupu $\mathrm{k}$ súdu a digitálneho vylúčenia, aj tu je na mieste položit si však najprv otázku, či automatizácia nemôže vytvorit novú prekážku v tomto aspekte. Ako už bolo naznačené v úvode, je to hádam práve táto zložka práva na spravodlivý proces, o ktorej už v súčasnosti vieme povedat, že by do určitej miery problematická byt mohla a nebude sa jednat len o odhad. Ako už bolo naznačené v úvode tejto podkapitoly, otázka zaujatosti je hojne rozoberaná na poli algoritmov aj v súčasnosti a rozhodne sa nejedná o ukončenú diskusiu s priamočiarym riešením.

Skôr naopak, jedná sa viac o všeobecne prijímaný fakt, že algoritmy a rôzne algoritmické procesy nie sú ani z d’aleka imúnne voči logickým pochybeniam, ktoré si bežne spájame s l’udským myslením, ako napríklad zaujatost’, predsudky, či ideologické zafarbenie. ${ }^{144} \mathrm{~K}$ vytváraniu zaujatých algoritmov môže dochádzat niekol'kými spôsobmi, jednak samozrejme vedome a účelne, a potom nevedome, bud’to využívaním chybných datasetov pri tvorbe (alebo pri následnom fungovaní algoritmického procesu), ktoré neboli skontrolované a nesú v sebe určitý druh zaujatosti, alebo jednoducho neuvedomovaním si a následným prenesením zaujatosti, a iných obdobných logických pochybení v uvažovaní, ktorým disponujú autori, do štruktúry algoritmu, ktorý navrhujú. ${ }^{145}$ Tieto rôzne pochybenia, resp. vady $\mathrm{v}$ procese často nemusia byt viditelné v mieste ich pôvodu, teda zaujatost' autora, ale $\mathrm{k}$ ich plnému dopadu na fungovanie a férovost procesu môže často dôjst' až pri ich plnom využívaní. ${ }^{146}$

Predpokladajme, že máme pripravený rozhodovací algoritmus, ktorý je zároveň potencionálne zaujatým. ${ }^{147}$ Pre zachovanie nárokov na spravodlivý proces by sme mali algoritmické rozhodovanie posudzovat podla rovnakých štandardov, aké aplikujeme na súčasné súdne konania, resp. v tomto

\footnotetext{
${ }^{144}$ Kitchin, R. Thinking critically about and researching algorithms. Information, Communica$\begin{array}{llll}\text { tion } \quad \text { \& } & \text { Society. } & \text { č. } 1 \text {. }\end{array}$ http://futuredata.stanford.edu/classes/cs345s/handouts/kitchin.pdf

${ }^{145}$ Hayes, P., Van de Poel, I., Steen, M. Algorithms and values in justice and security. AI \& SOCIETY. 2020, č. 3.
} 
prípade sudcov. Inak povedané, pri podozrení algoritmu zo zaujatosti by sme ho mali podrobit subjektívnemu a objektívnemu testu, ktorý pri zaujatosti skúma ESL’P aj Ústavný súd. ${ }^{148}$

Na prvý pohlad by sa mohlo zdat', že subjektívny test by nemal predstavovat problém pre algoritmické rozhodovanie. Tento test bol celkom pochopitel’ne zavádzaný $s$ ohl’adom na l'udských sudcov, a teda je náročné striktne nasledovat otázky tohto testu, akými sú predchádzajúce výroky, záujmy na výsledku, či osobné sympatie a antipatie u automatizovaného rozhodovania, pri ktorom často očakávame práve akúsi „ideologickú slepotu“, ktorá by mala tieto negatívne aspekty odstrániti. ${ }^{149}$ Toto je však ideálny scenár, ktorého sa nám zatial' nedarí dosiahnute.

Takmer až hlúpo jednoduchým riešením sa v tomto prípade môže javit neposkytovanie údajov o tzv. „chránených charakteristikách“, na základe ktorých môže dochádzat ku skresleniu rozhodovania, typicky napríklad

${ }^{146}$ Tu vid' napr. článok Amazon scraps secret AI recruiting tool that showed bias against women [online]. [cit. 02.02.2021]. https://www.reuters.com/article/us-amazon-com-jobsautomation-insight/amazon-scraps-secret-ai-recruiting-tool-that-showed-bias-againstwomen-idUSKCN1MK08G, alebo MURRAY, John, 2019. Racist Data? Human Bias is Infecting AI Development. $\quad$ Medium [cit. 02.02.2021]. https://towardsdatascience.com/racist-data-human-bias-is-infecting-aidevelopment-8110c1ec50c - k takémuto efektu dochádza z dôvodu, že algoritmizáciou sa rozhodovacie procesy často koncentrujú do jedného bodu a to vo vel'kých počtoch, preto je omnoho jednoduchšie v nich pozorovat diskriminačné vzorce. Pred takýmto efektom varuje aj CEPEJ vo vyššie spomínanej Etickej Charte CEPEJ. European ethical Charter on the use of Artificial Intelligence in judicial systems and their environment [online]. s. 9.

${ }^{147}$ Problém a mechanizmus zaujatosti v algoritmoch je samozrejme podstatne komplexnejší než je v texte naznačené a jeho bližší rozbor je nad rozsah článku. Pre bližší, avšak stále „prístupný“ prehl'ad o vzniku tohoto problému odkazujem čitatel'a na napr.: Barton, N. T.L., Paul Resnick, and Genie. Algorithmic bias detection and mitigation: Best practices and policies to reduce consumer harms [online]. Brookings. 22. 5. 2019 [cit 6. 2. 2021]. https://www.brookings.edu/research/algorithmic-bias-detection-and-mitigation-bestpractices-and-policies-to-reduce-consumer-harms/. Prípadne k vzniku zaujatosti v algoritme na základe nereprezentatívnych, resp. chybných či zaujatých dát vid napr.: Praharaj, K. How Are Algorithms Biased? [online]. Medium. 29. 6. 2020 [cit 6. 2. 2021]. https://towardsdatascience.com/how-are-algorithms-biased-8449406aaa83

${ }^{148}$ Vel'mi podstatnou je pre riešenie tohto problému aj otázka transparentnosti a otvorených algoritmov, o ktorej bude však bližšie pojednané d’alej.

${ }^{149}$ Ettekoven, B., Prins, C. Data analysis, Artificial Intelligence and the Judiciary system. In: Mak, V. et al (eds.). RESEARCH HANDBOOK IN Data Science and Law. Northampton: Edward Elgar Publishing, 2018, s. 425 - 447. 
pohlavie alebo rasa. Tento koncept je známy ako "fairness through unawarness" a je často považovaný za základný prístup k algoritmickej spravodlivosti. ${ }^{150}$ Úskalím tohto prístupu je však skutočnost', že dáta, ktoré sa na prvý pohlad môžu javił ako zbavené akýchkolvek chránených charakteristík, v sebe $\mathrm{v}$ skutočnosti môžu niest̉ nepriame stopy týchto charakteristík, obsiahnuté vo vzorcoch, ktoré sú pre človeka, na rozdiel od expertného systému, nespozorovatel'né. ${ }^{151}$

Od toho sa potom odvíja aj druhý, naznačený problém subjektívneho testu, že algoritmus síce je „ideologicky slepý“, tak ako by sme chceli, problém je ten, že jeho tvorca zrejme nie je, a to vel’mi často nevedome. Čo je $\mathrm{v}$ tejto situácii horšie, nakol'ko potom nevie s takýmto skreslením počítat. ${ }^{152,153}$

Posúdenie subjektívnej zložky zaujatosti je značne komplikované, najmä s ohladom na antropocentrickost' subjektívneho testu a sprostredkovanie zaujatia v algoritme. Otázkou je, či by cestu von z tejto situácie mohol poskytnút objektívny test, respektíve inštitucionálne záruky a s nimi spájaná

${ }^{150}$ Kusner, M. J. et al. Counterfactual Fairness. V: Guyon, I. et al. (ed.). Advances in Neural Information Processing Systems 30. Curran Associates, Inc., 2017. http://papers.nips.cc/ paper/6995-counterfactual-fairness.pdf

${ }^{151}$ Napríklad vyššie spomínaný COMPAS berie často v úvahu predchádzajúcu kriminálnu históriu, čo je však z pohladu mnohých neštastné s ohl’adom na disproporčnú prítomnost̉ afroameričanov $\mathrm{v}$ trestnom systéme s odkazom na celkový problém rasovej nevyváženosti trestného systému v USA, ktorý sa doň dostávajú v omnoho nižšom veku a z omnoho bagatel’nejších dôvodov. Prípadne systém odvodí sociálny štatút, napríklad žiadatela o pôžičku, z jednoduchého údaju o adrese, ktorý sa na prvý pohlad môže zdat neutrálnym, no v spojení s inými údajmi, či predchádzajúcim "tréningom“ algoritmu môže viest’ k zvažovaniu inak chránených a „ignorovaných“ charakteristík. K tomu: LARSON, Jeff, ANGWIN, Julia. How We Analyzed the COMPAS Recidivism Algorithm. ProPublica, 2016 [online] [cit. 18.03.2020]. Dostupné z: https://www.propublica.org/article/how-weanalyzed-the-compas-recidivism-algorithm, K rozdielom vnímania používaných charakteristík pre posudzovanie prepustenia medzi rasovo odlišnými skupinami pozri tiež GRGIC-HLAC A, Nina, et al. The Case for Process Fairness in Learning: Feature Selection for Fair Decision Making. Semanticscholar.org [online] [cit. 17.03.2020]. Dostupné z: https://people.mpi-sws.org/ gummadi/papers/process_fairness.pdf

${ }^{152} \mathrm{~K}$ problému nevedomej zaujatosti u ludí pozri napr.: Banaji, M. R., Greenwald, A. G. Blindspot: Hidden Biases of Good People. Delacorte Press, 2013.

${ }^{153}$ Praharaj, K. How Are Algorithms Biased? 
funkčná nezávislost', ktorej posudzovanie sa javí ako vhodnejšie než skúmanie „vystupovania navonok“ expertného systému. ${ }^{154}$

Takouto funkčnou zárukou je z pohl'adu ESL’P najmä osobné zloženie jednotlivých inštancií, resp. jeho rozdielnost na jednotlivých stupňoch. Opät máme test, ktorý nie je úplne priamo aplikovatel’ný v prípade algoritmického rozhodovania. Funkčné záruky sú relevantné v momente viac inštančného súdneho konania. Ak by sme sa $\mathrm{v}$ tomto bode chceli vyhnút rozprave o reflektovaní automatizácie súdneho rozhodovania $\mathrm{v}$ procesnom práve všeobecne, môžeme alibisticky poskytnút inštitucionálnu záruku v následnej kontrole ludským sudcom, na ktorú by sa vztahovali dalej rovnaké pravidlá aké poznáme $\mathrm{v}$ súčasnosti. ${ }^{155} \mathrm{Je}$ potom na mieste si položit otázku, do akej miery by sa jednalo o expertný systém a do akej miery, resp. v ktorom bode, by sme sa začali rozprávat skôr o tzv. „podpornom sudcovskom systéme“ “ ${ }^{156}$ A možno podstatnejšie pre túto prácu, by sme si potom museli položit nadväzujúcu otázku: Ak nie sme schopní zaistit plnú automatizáciu súdneho procesu, znamená to, že je takýto proces nezosúladitel’ný s právom na spravodlivý proces?

Ako $\mathrm{v}$ jednom z mála bodov tejto práce si pred takto unáhlenou otázkou môžeme dopomôct̉ zhodnotením existujúcej právnej úpravy v podobe kanadskej Directive on Automated Decision-Making. ${ }^{157}$ V súčasnosti je aj toto nariadenie zamerané podla vlastnej preambule skôr na podporné sudcovské systémy, ${ }^{158}$ avšak niektoré z pravidiel, ktoré stanovuje pre takúto čiastočnú

${ }^{154}$ V kontexte algoritmov by sme za faktor „vystupovania navonok“ mohli podla názoru autora považovat jednako transparentnost', resp. otvorenost' algoritmu ako aj posudzovania a následné odstráňovanie nevhodných vzorcov v rozhodovaní algoritmu. O oboch bude pojednané d’alej.

155 Ostatne, obdobným spôsobom to momentálne rieši aj Všeobecné nariadenie o ochrane údajov v čl. 22.

${ }^{156}$ K rozdielu bližšie napr. DYMITRUK, M. The Right to a Fair Trial in Automated Civil Proceedings. In: Masaryk University Journal of Law and Technology [online]. 2019, vol. 13(1), no. $27, \quad$ s. $27 \quad$ - $43 . \quad$ ISSN 1802-5951, 1802-5943. https://journals.muni.cz/mujlt/article/view/11624/10663

157 SECRETARIAT, Treasury Board of Canada, 2019. Directive on Automated Decision-Making [online]. In: TBC [cit. 18.03.2020]. https://www.tbs-sct.gc.ca/pol/doc-eng.aspx?id=32592

158 Ibid. 
implementáciu algoritmického rozhodovania sa javia byt vhodnými aj pre plne implementované expertné systémy.

Prvým pravidlom, ktoré je spomínané nariadením je pravidelné posudzovanie výsledkov takéhoto rozhodovania s dôrazom na možné negatívne dopady. $\mathrm{V}$ prípade vypozorovania takéhoto negatívneho vzorca nariadenie ukladá povinnost̉ ho bez d’alšieho odstránit.t. ${ }^{159}$

Toto samozrejme nie je jediná záruka. Toto nariadenie d’alej ukladá zabezpečenie ludského prieskumu automatizovaného rozhodnutia a posúdenia dopadu automatizovaného rozhodovania ešte pred jeho zavedením. ${ }^{160}$

Zhodne to vníma aj CEPEJ, ktorý vo svojej Etickej charte predpokladá odhal'ovanie a bezprostredné odstraňovanie ako negatívnych dopadov, tak aj systémovej chyby, ktorá $\mathrm{k}$ nim viedla v prvom rade. ${ }^{161}$

Odpoved' na otázku funkčnej nezávislosti bude zrejme v procesnej úprave využívania takýchto systémov, čo nutne nemusí znamenat ich úpravu, tak ako sme sa tomu snažili vyhnút už v predchádzajúcich častiach tejto práce, skôr by sa malo jednat o zasadenie automatizovaného systému do už existujúcich pravidiel.

$\mathrm{V}$ prvom rade je nutné si uvedomit priebeh viac inštančného rozhodovania $\mathrm{v}$ súčasnosti, ktoré je $\mathrm{v}$ podstate prípustné len pre vymedzené dôvody. Ak sa jedná o uplatnenie nových dôkazov, nemali by vznikat obavy o funkčnú nezávislost', nakol'ko by daný systém rozhodol na základe upravených vstupných dát, $\mathrm{v}$ zásade ako nový prípad, nakol'ko na rozdiel od ludí takýto systém bude asi len tažko disponovat vôlou zotrvat vo svojom predchádzajúcom rozhodnutí ako signál vlastnej neomylnosti.

Ďalšie námietky ako nepríslušnost', či vylúčenie sudcu sú v tomto prípade bezpredmetné. Nesprávne posúdenie veci, čo do konečného skutkového stavu ako aj právneho stavu (eventuálne aj abstraktná kategória vady

159 Článok 4 a článok 6, Directive on Automated Decision-Making.

${ }^{160}$ Toto nariadenie sa vztahuje obecne na verejnoprávne vztahy, preto sú ním zavádzané opatrenia obecnejšieho charakteru tak aby mohli byt nasadené aj na rôzne iné správne rozhodnutia.

${ }^{161}$ CEPEJ. European ethical Charter on the use of Artificial Intelligence in judicial systems and their environment. s. 9. Prípadne bod 10.1 tejto Charty. 
majúcej za následok nesprávne posúdenie veci), sa javia ako také, ktoré si bude vyžadovat zásah z l’udskej strany, nakol'ko ich opätovné posúdenie rovnakým algoritmom musí zákonite vieste $\mathrm{k}$ rovnakému, $\mathrm{v}$ tomto prípade zrejme chybnému, záveru. Takéto presunutie rozhodovania z expertného systému na l'udského sudcu však nemožno vnímat ako nemožnost̉ dodržania nárokov na spravodlivý proces o nič menej, než by sme ich takto mohli vnímat pri rozhodnutí prvo-inštančného sudcu, voči ktorému bolo podané odvolanie.

Jediná otázka funkčnej zaujatosti je preto na mieste len pri uplatnení nových dôkazných materiálov. Tieto však z technických daností stanoveného problému povedú $\mathrm{k}$ novému rozhodnutiu, ktoré je zbavené akéhokolvek vztahu k rozhodnutiu predchádzajúcemu. Pri probléme chybného posúdenia veci by sme museli dospiet $k$ absolútnej funkčnej zaujatosti, nakolko rozhodnutia budú identické. Avšak riešením tohto problému je zachovanie existujúceho systému inštančného prieskumu, kedy ani v súčasnosti nie je prípustné, aby ho vykonával ten istý jedinec.

Vo všeobecnosti budeme musiet tuto otázku uzavriet s relatívne neuspokojivou odpoved’ou. Expertné systémy rozhodne nie sú ideálnym riešením zbaveným akejkolvek formy zaujatosti, či skresl’ovania logického rozhodovacieho postupu. Táto chyba je však nanajvýš porovnatel’ná s tou, akú môžeme pozorovat $v$ súčasnosti u l'udských sudcov, čo môže byt demonštrované jednako na skutočnosti, že môže byt odstránená rovnakými zárukami, aké poskytujeme v systéme luudských sudcov, ako aj na fakte, že je do vel'kej miery na tieto systémy prenesená l'ud'mi pri ich tvorbe. Navyše, je však možné tieto chyby $\mathrm{v}$ expertných systémoch postupne odstránit úplne dodržiavaním imperatívu predpokladaného existujúcimi dokumenta$\mathrm{mi}, \mathrm{k}$ ich cielenému odhal'ovaniu a odstraňovaniu, ako aj snahou o ich odhalenie ešte pred samotnou implementáciou systému. Aspekt nestrannosti a nezaujatosti súdneho rozhodovania nie je pre expertné systémy absolútnou prekážkou, treba však klást dôraz na dostatočné procesné záruky, ako aj kontrolu a kich užívaniu minimálne zo začiatku pristupovat nanajvýš obozretne. 


\subsection{PRÁVO NA VEREJNÉ KONANIE}

Ďalším aspektom, ktorý bol vyššie identifikovaný ako konštitutívny pre právo na spravodlivý proces je verejnost', ktorá v sebe zahŕňa ako verejné konanie, tak aj verejné vynesenie rozsudku. $\mathrm{V}$ predchádzajúcej kapitole sme mohli vidiet, že väčšina nárokov na spravodlivé konanie, ktoré v súčasnosti existujú, sú vytvárané priamo na mieru súdneho konania pred „ludským“ sudcom, a teda nemusia byt priamo aplikovatel'né na iné druhy súdneho konania, akým by automatizované rozhodovanie dozaista bolo. Takýto stav však sám o sebe ešte neznamená, že automatizované súdne rozhodovanie nemôže zabezpečit nároky práva na spravodlivý proces. Pre tento záver je však nutné najprv pochopit účel verejného konania a vyhlasovania rozsudkov.

Molek uvádza, že verejnost̉ konania má dvoch adresátov. Jednak sú to strany sporu, ktorým má tento aspekt poskytnút záruku kontroly ako ochrany pred zneužitím právomoci, akúsi istotu, že proti súdnemu aparátu „nestoja sami“. Druhým adresátom tohto práva je verejnost̉ ako taká, ktorej verejné konanie zaručuje možnost̉ kontrolovat a mat prehl'ad o tom, ako je spravodlivost̉ vykonávaná v mene ich krajiny. ${ }^{162}$ Takúto formu kontroly zo strany verejnosti označil Ústavný súd vel'mi poeticky ako „súdenie za bieleho dňa" v náleze Pl. ÚS $2 / 10$, kde sa vyjadril aj k skutočnosti, že adresátom tohto práva je práve $\mathrm{z}$ dôvodu kontroly a verejnej diskusie aj široká verejnost'. Takto verejné súdenie a kontrola majú zvyšovat autoritu súdov a ich rozhodnutí, a to najmä prostredníctvom pocitu verejnosti, „že nie je čo skrývat". ${ }^{163}$

Podobne ako predchádzajúci aspekt, aj verejnoste je reflektovaná na zákonnej úrovni $\mathrm{v}$ českom právnom poriadku, v relevantných predpisoch pre každý druh konania. Jedná sa napríklad o § 116 zákona číslo 99/1963 Sb., občanský soudní řád, ktorý hned' v prvom odstavci stanovuje, že súdne konania sú verejné (s výnimkou konaní, ktoré vykonávajú notári). Svoboda v komentári $\mathrm{k}$ tomuto ustanoveniu uvádza, že sa skutočne jedná

\footnotetext{
${ }^{162}$ Molek. Právo na spravedlivý proces, s. 210.

${ }^{163}$ Nález Ústavného súdu zo dňa 30. marca 2010, sp. zn. Pl. ÚS 2/10, bod 43.
} 
o ukotvenie predpokladu práva na spravodlivý proces, a teda stanovené výnimky z tohto práva musia byt jednak skutočne výnimočné a jednak musia sledovat závažný dôvod, ako napríklad podstatný verejný záujem alebo zachovanie poriadku. ${ }^{164}$ Ďalej tiež uvádza, že toto právo je rozšírené aj na vyhlásenie rozsudku, ktoré musí byt verejné. Čo je pre verejnú kontrolu súdnej moci natol'ko podstatné, že nie je možné vylúčit verejnost’ zo žiadneho dôvodu a súd je povinný zabezpečit priebeh konania iným spôsobom (ako napríklad posilnenie justičnej stráže). ${ }^{165,166}$

Základom takejto zákonnej úpravy je potom článok 38 Listiny, resp. jeho druhý odstavec, ktorý každému zaručuje právo na verejné prejednanie jeho veci a podl’a Baňoucha je to práve verejnost’ jednania, ktorá odlišuje súdne rozhodnutia od iných rozhodnutí moci verejnej. ${ }^{167}$ Molek, s odkazom na rozhodnutia Ústavného súdu, k tomu uvádza, že obzvlášt v kontexte Českej republiky, má tento aspekt zvláštnu závažnost’ s ohl'adom na historickú skúsenost’ „kabinetnej“ justície, ktorá slúžila vládnej garnitúre a nie spravodlivosti. ${ }^{168}$ Baňouch sa tiež zhoduje s pôvodným účelom tohto aspektu, že sa nejedná o ,jednoduchú“ technikalitu súdneho procesu, ale že ide o aspekt vlastný demokratickej spoločnosti, ktorý má zabezpečiť všeobecné povedomie o spravodlivosti, a týmto zabezpečit verejnú kontrolu súdnej moci, ktorá má zase dopomôct' k zvýšeniu dôvery v spravodlivost.. ${ }^{169}$ To samozrejme neznačí absolútny charakter tohto aspektu, no s ohladom na tento význam treba akékol'vek obmedzenia, ktoré sú v tomto prípade už rovno stanovené zákonom, vykladat’ vel'mi reštriktívne a ich zavádzanie musí byt proporčné. ${ }^{170}$ Rovnako to je potom aj pri rozsudkoch, kde Baňouch chápanie verejnosti rozširuje nielen na ich samotné vyhlásenie, ale aj na

\footnotetext{
${ }^{164}$ Svoboda, K. § 116 [Veřejnost jednání]. In: Svoboda, K., et al. Občanský soudní řád. 2. vydání. Praha: Nakladatelství C. H. Beck, 2017, s. 497. 
následnú verejnú dostupnost’ rozsudkov s ohl’adom na čo spochybňuje možnost̉ anonymizácie rozsudkov, s tým, že občan ako „konzument statku spravodlivosti“ musí chápat, že sa jej domôže iba na výhradne verejnom fóre. $^{171}$

Spomínaný komentár sa z vel’kej časti sám odvoláva na úpravu v Dohovore a interpretáciu tohto aspektu v rámci článku 6 Dohovoru, najmä s ohl'adom na frekvenciu s akou sa k tomuto aspektu ESL'P vyjadruje. Celkovo je aj ponímanie verejnosti v Dohovore do vel'kej miery identické s tým $\mathrm{v}$ Listine.

Harris sa vo svojom výklade v zásade zhoduje $s$ interpretáciou tohto aspektu čo do jeho významu, teda záruky verejnej kontroly ako ochrana jednotlivca pred možným zneužitím zo strany štátnej moci. Oproti Baňouchovi, ktorý verejnost’ rozširuje na vyhlasovanie rozsudkov a ich prístupnost', ju Harris rozširuje aj na potrebu ústneho konania, čiže výhradne písomné prejednanie veci podl’a neho nie je v súlade $\mathrm{s}$ týmto aspektom práva na spravodlivý proces. ${ }^{172}$

Nedostatok verejnosti súdneho procesu považuje za tak vážne narušenie férovosti procesu, že je možné ho napravit iba obnovou procesu, či „nahradením“ kompletne verejným druho-inštančným prejednaním v plnom rozsahu. $^{173}$

Podobne ako Listina aj Dohovor stanovuje určité výnimky, ktoré sú za prvé taxatívne stanovené článkom 6 a za druhé aj tie musia byt̉ vykladané reštriktívne. Podl’a záverov Komisie musia byt jednako vždy proporčné a takisto musia reagovat̉ na závažnú spoločenskú potrebu. ${ }^{174} \mathrm{~V}$ rámci takéhoto výkladu je však celkovo prípustné z verejného prejednania vylúčit celú skupinu prípadov, na základe niektorej z podmienok článku 6, ako to môžeme často vidiet’ pri súdnych konaniach vo veciach neplnoletých. ${ }^{175}$

\footnotetext{
171 Ibid.

${ }^{172}$ Harris, O'Boyle, Warbrick. Law of the European Convention on Human Rights, s. 271.

173 Ibid.

${ }^{174}$ Vid' napr. Campbell a Fell proti Spojenému král'ovstvu, rozsudok Európskeho súdu pre l'udské práva, 28.06.1984 č. stažnosti 7819/77, odstavec 87.

${ }^{175}$ Harris, O’Boyle, Warbrick. Law of the European Convention on Human Rights, s. 273.
} 
V prípadoch takéhoto obmedzenia môžeme vidiet' obmedzenie tohto práva na jeho základnú myšlienku, ktorou je zabezpečenie verejnej kontroly výkonu súdnej moci, a to vo forme povinného verejného rozsudku, aspektu verejnosti, od ktorého sa na rozdiel od samotného konania odklonit nedá. $^{176,177}$

Aspekt verejnosti súdneho konania zaručuje všetkým účastníkom prejednanie veci za účasti verejnosti s taxatívne vymedzenými možnými obmedzeniami a rovnako aj verejné vyhlásenie rozsudku. A to takým spôsobom, aby bola zabezpečená možnost̉ verejnej kontroly výkonu súdnej moci z dôvodu ochrany jedinca stojaceho pred súdom pred zneužívaním štátneho monopolu a takisto aj zvýšenie transparentnosti výkonu súdnej moci, ktorá má viesṫ k posilneniu jej dôveryhodnosti. Otázka, ktorú si teraz musíme položit je, či je možné zosúladit všetky tieto požiadavky s automatizovaným súdnym procesom.

V úvode tejto časti bolo naznačené, že aspekt verejnosti nebude zrejme priamo preveditel'ný v jeho súčasnej podobe na automatizované rozhodnutia, čo však nutne neznamená, že nebude možné nijako dosiahnut rovnakého ciel’a, aký je sledovaný aspektom verejnosti v jeho súčasnej podobe. Do určitej miery síce môžeme uvažovat’ o nejakom expertnom systéme, ktorý bude produkovat v reálnom čase log svojho procesu. Efektívnost̉ takéhoto „teatrálneho“ nastavenia je otázna v súvislosti s pôvodným zámerom verejnosti - možnosti verejnej kontroly. Skôr než sa všemožne snažit nasadit expertné systémy na formu procesu ako ho poznáme teraz, je na mieste zaoberat sa tým, ako expertným systémom zaručit verejnú kontrolu.

Otázka verejnej kontroly expertných systémov je v zásade otázkou ich transparentnosti. ${ }^{178}$ Transparentnost je potom problém, ktorý je v súčasnosti hojne diskutovaný aj na poli počítačovej vedy a často sa o ňom uvažuje aj ako o „explainable“ AI. ${ }^{179}$ Ulenaers vo svojej eseji varuje pred problémom utajovania algoritmov, vyvinutých súkromnými spoločnostami, z dôvodu

\footnotetext{
${ }^{176}$ Ibid., s. 276.

${ }^{177}$ Harris poukazuje na určitú úroveň „flexibility“ čo sa týka verejnosti rozsudkov, tá však nedosahuje takej miery, aby sme ju mohli označit za obmedzenie a zahŕňa skôr „technikality“ ako anonymizáciu kontaktných údajov neplnoletých, alebo predčítanie len skrátenej verzie rozsudku.
} 
ochrany obchodného tajomstva, čo je napríklad jeden z problémov COMPASu. Vo vyššie spomínanom rozsudku State v. Loomis je to práve otázka obchodného tajomstva, resp. stažovatel’ova námietka nemožnosti zoznámenia sa s procesom, na základe ktorého bol odsúdený, s ktorou sa súd z autorovho pohl'adu nezvládol vysporiadat’ a záverom vyslovil odporúčanie nepoužívat proprietárne algoritmy, resp. ich užívanie pozastavit kým ich proces nebude bližšie ozrejmený alebo aspoň lepšie otestovaný. ${ }^{180}$ Obdobne alibistický prístup volí aj Ulenaers, ktorý ako jediné východisko z tejto situácie vníma obmedzenie automatizovaných systémov len na rolu podporného sudcovského systému, kedy by sudca suploval verejnosṫ konania a zároveň by sa tým znížil dôraz na transparentnoste expertného systému, ked’že by konečné rozhodnutie vyslovil, a teda aj odôvodnil, sudca. ${ }^{181}$

Z pohl'adu tejto článku by však záver, že tento problém je možné vyriešit iba ak budú expertné systémy postavené do úlohy podporného sudcovského systému, musel viest' $\mathrm{k}$ odmietnutiu tézy.

V prvom rade je potrebné poukázat’ na to, že vo State v. Loomis súd zrejme túto podmienku nepovažoval za absolútnu prekážku a v záverečnom odporúčaní sa vyjadril smerom k potrebe zvýšenej kontroly, respektíve celú

${ }^{178} \mathrm{~K}$ rýchlemu exkurzu k transparentnosti sudcovského rozhodovania vid” napr. Eddins, K. Úvodné poznámky ku konferencii VIA IURIS „Presvedčivost” a transparentnost rozhodovania súdov. In: Kovačechová, E., Wilfling, P. (eds). Prístup $k$ spravodlivosti - bariéry a východiská Pezinok: VIA IURIS, 2010, s. 5. Najmä potom: „Skutočná transparentnost’ zahŕňa viac než len otvorenú justíciu; je o pochopení toho, čo súdy robia a prečo“. Prípadne $\mathrm{v}$ tej istej publikácii potom Kovačechová, E., Wilfling, P. PRÍSTUP K SPRAVODLIVOSTI - VÝCHODISKÁ A BARIÉRY: Presvedčivost' a transparentnost' rozhodovania súdov [online]. Pezinok: Via Iuris, 2010. https://viaiuris.sk/wp-content/uploads/2017/08/pilk-2009.pdf

${ }^{179}$ Etická charta CEPEJ (CEPEJ. European ethical Charter on the use of Artificial Intelligence in judicial systems and their environment. s. 11.) sa tiež vyjadruje $\mathrm{k}$ „explainability“ ako $\mathrm{k}$ možnému prístupu k transparentnosti. Tento koncept vníma ako vysvetlenie procesu v „bežnom“ jazyku. Zaistenie pochopenia automatizovaného procesu širokou verejnostou je určite správny krok, ktorý povedie $\mathrm{k}$ väčšej dôvere $\mathrm{v}$ takéto systémy, no ako bude spracované d’alej v texte, jedná sa o trochu odlišný prístup ku konceptu „explainability“, než ako s ním bude nakladat tento text. $\mathrm{V}$ intenciách tohto textu bude tento koncept predstavovat odstránenie „black box“ algoritmu a to takým spôsobom, ktorý zaručuje kontrolu jeho procesu, nie len výsledku. Explainable AI zároveň nezahŕňa právo na odôvodnený rozsudok, ktorým sa bude táto práca zaoberat d’alej.

${ }^{180}$ State $v$. Loomis.

${ }^{181}$ Ulenaers. The Impact of Artificial Intelligence on the Right to a Fair Trial, s. 29. 
diskusiu ohladom transparentnosti ukotvil v možnosti kontroly činnosti expertného systému. Ulenaers sa pred svojím unáhleným záverom o obmedzení expertného systému len na podpornú rolu rovnako zaoberal doktrinálnym výkladom významu aspektu ústnosti (resp. verejnosti). V súlade $s$ vyššie uvedeným výkladom, okrem iného ESL’P, o ktorý sa opiera aj Ulenaers, ho vykladá ako aspekt, ktorý má zabezpečit kontrolu verejnosti a tá má výmenou zariadit ochranu jedinca pred zneužívaním štátnej moci. $^{182}$

S opätovným odkazom na argumentáciu stažovatel’a v State v. Loomis, je možné povedat, že problém transparentnosti je dvojakého charakteru. Za prvé je to problém „skrývania“, čiže úmyselnej netransparentnosti z dôvodu obchodného tajomstva.

Druhý problém plynie z technických vlastností technológií, ktoré by potencionálne mohli byt’ $\mathrm{k}$ aplikácii algoritmov na rozhodovanie použité. Podobne ako niektoré predchádzajúce problémy aspektov, ktoré boli už spomínané, aj tento problém má značný presah do oblasti počítačovej vedy a problém explainability, prípadne tzv. „black box“ problém je predmetom rozsiahleho výskumu.

Ako poukazuje Mittelstadt et al., byt’ schopný porozumiet rozhodovaciemu algoritmu má význam pre osoby zúčastnené na oboch stranách. $\mathrm{Na}$ jednej strane je to potrebné pre tvorcu ako možnost̉ kontroly fungovania systému a jeho následnej úpravy $\mathrm{v}$ prípade negatívnych javov, ako je napríklad vyššie spomínaná zaujatosṫ. A na druhej strane je to potrebné pre strany sporu, aby vedeli upravit svoju procesnú stratégiu a aby boli sami schopní kontrolovat výkon súdnej moci. ${ }^{183} \mathrm{~V}$ úvode upozorňujú na to, ako súčasné postupy strojového učenia vedú síce $\mathrm{k}$ omnoho presnejším a vhodnejším výsledkom, avšak za cenu nášho všeobecného neporozumenia spôsobu, akým sa daný systém dopracuje k výsledku. ${ }^{184}$

${ }^{182}$ Ibid.

${ }^{183}$ Mittelstadt, B., Russell, C., Wachter, S. Explaining Explanations in AI. Proceedings of the Conference on Fairness, Accountability, and Transparency. 2019.

${ }^{184}$ Čo dáva do kontrastu s pôvodnou symbolickou umelou inteligenciou, ktorej každý „riadok kódu“ bol manuálne naprogramovaný a teda existoval medzi developermi obecný prehlad o fungovaní takéhoto systému. Vid': Susskind. Online courts and the future of justice, s. 288. 
Mittelstadt et al. delia explainability na dve podkategórie - transparentnost' a post-hoc interpretovatel'nost. ${ }^{185}$ Druhou kategóriou sa budeme zaoberat’ v nasledujúcej časti práce. Transparentnost’ systému je podl'a nich možné dosiahnut len za splnenia troch kritérií, resp. v momente, kedy je človek schopný porozumiet každému z nich. Malo by sa jednat o pochopenie modelu (algoritmu) ako celku, jeho jednotlivých komponentov (parametrov) a porozumenie príslušného trénovacieho algoritmu. Ako to sami autori zjednodušili, je potrebné pochopit fungovanie celého algoritmu ako procesu a jeho jednotlivých zložiek. ${ }^{186}$ Ako jedno z východísk pre explainable AI vnímajú vytváranie aproximatívnych modelov, ktorých jedinou funkciou má byt vysvetlenie aproximovaného modelu, ideálne takým spôsobom, ktorý bude pochopitel’ný aj pre laika. ${ }^{187}$ Takýto prístup však kladie dôraz iba na pochopenie modelu na strane „spotrebitel’a“ - v našom prípade na strane účastníkov sporu a nerieši problém nutnosti porozumenia expertného systému na strane jeho tvorcu, teda na strane, kde by malo dochádzat' k odhal'ovaniu a hlavne odstraňovaniu možných negatívnych javov.

Susskind vo svojej práci o ODR systémoch, ktoré nie sú nutne synonymom algoritmického rozhodovania, no slúžia ako vel’mi vhodný podklad pre uvažovanie o bližšom fungovaní expertných systémov, rozlišuje transparentnost' rozhodovania na dva druhy. ${ }^{188}$ Prvým je transparentnost’ v skutočnom čase („real-time transparency“), čo je ten druh transparentnosti, ktorý máme na mysli, ked’ rozprávame o podmienke verejnosti (a s ňou spojeným aspektom ústnosti, ktorej sa budeme venovat’ v nasledujúcej časti práce). V skratke sa jedná o transparentnost̉ zaručenú možnostou reálneho pozorovania procesu v mieste jeho konania. Susskind to d’alej rozvádza ako podmienku verejného fóra, na ktorom pojednávanie prebieha a možnoste prístupu a reportovania médií. ${ }^{189}$

\footnotetext{
185 Mittelstadt, Russell, Wachter. Explaining Explanations in AI.

186 Ibid.

187 Ibid.

188 Susskind. Online courts and the future of justice, s. 194.

189 Ibid.
} 
Druhou kategóriou transparentnosti, ktorá sa vracia spät k dôvodom, prečo vôbec takýto aspekt existuje, je informačná transparentnost'. Susskind ju stotožňuje zároveň s požiadavkou otvorenej justície. Informačná transparentnost’ by sa mala nachádzat’ na dvoch úrovniach, jednako na úrovni celého systému spravodlivosti a takisto na úrovni individuálnych prípadov. Na globálnej úrovni je pre informačnú transparentnost' nevyhnutné zabezpečit prístup k procesu ako takému, ${ }^{190}$ postupom súdu a jeho fungovaniu, prístup k dátam o množstve pridelených a rozhodnutých prípadov, o ich predmete a dopade, prístup k rozpisu pojednávaní, prístup $\mathrm{k}$ rozhodnutiam a nákladom na fungovanie plynúcich $\mathrm{z}$ verejného rozpočtu. $^{191}$

Informačná transparentnost’ na úrovni individuálnych prípadov sa podla Susskinda skladá z verejného prístupu k včasne oznámeným informáciám o konaní, k záznamu z konania, informáciám o zúčastnených stranách, podstate a druhu sporu, informácie o priebežných nemeritórnych rozhodnutiach, k obsahu rozhodnutia ako aj k jeho odôvodneniu. ${ }^{192}$

Susskind poukazuje na to, že takáto informačná transparentnost̉ je v súčasnosti vcelku vel'mi nízka, a to bez ohl'adu na to ako vel’mi sú súdy danej krajiny otvorené verejnosti v „reálnom čase“. Vytváranie dát, ktoré sú potrebné pre zaistenie informačnej transparentnosti by pritom malo byt prirodzeným vedl'ajším produktom digitálnej justície, a teda ich sprístupnenie širokej verejnosti na internete by ostalo čisto politickou otázkou. $^{193}$ Jedinou otázkou $\mathrm{v}$ tomto prípade teda ostáva, či je možné kompenzovat’ stratu transparentnosti „V reálnom čase“ informačnou transparentnostou.

Susskind sa najprv zaoberá rozličnými výhodami distribuovanej spravodlivosti, resp. širšieho využívania ODR, ktoré by podla neho mohlo

\footnotetext{
${ }^{190}$ Prístupom sa v tomto prípade nemyslí faktický prístup, napríklad do súdnej siene, Susskind používa termín „visibility“, ktorý je s ohl’adom účel tohto aspektu vhodnejší a má skôr označovat reálnu možnost̉ sa s priebehom procesu oboznámit, viac než mat ku konaniu skutočný prístup.

${ }^{191}$ Susskind. Online courts and the future of justice, s. 194.

${ }^{192}$ Ibid.

${ }^{193}$ Ibid., s. 195.
} 
kompenzovat zníženie transparentnosti v reálnom čase. Rôzne iné aspekty zavádzania automatizovaných rozhodovacích systémov sú rozoberané naprieč touto prácou, preto ich rekapitulácia nie je na mieste, a vzájomné porovnávanie výhod a nevýhod jednotlivých aspektov voči sebe prenechávame inej práci. Namiesto toho sa zameriame na Susskindove argumenty, ktoré proti sebe stavajú tieto dva druhy transparentnosti.

Susskind poukazuje na neabsolútny charakter podmienky ústneho konania, podobne ako bolo opísané v úvode tejto častia d’alej upozorňuje na to, že to, čo označuje za transparentnost̉ $\mathrm{v}$ reálnom čase, by po správnosti malo byt skôr označené ako obmedzená transparentnost v reálnom čase. Otvorený súd, teda vol’ne prístupné verejné pojednávanie síce predstavuje vrchol tohto druhu transparentnosti, no Susskind poukazuje na to, že otvorené súdne pojednávanie nám neposkytuje bližší prehlad o rozhodovacom procese, ale o priebehu procesu navonok. Inak povedané, samotná skutočnost', že môžeme byt̉ so sudcom spolu v jednej miestnosti, nám nijakým spôsobom neposkytuje vhl’ad do jeho rozhodovania. ${ }^{194}$ Tento vhl’ad nám do rozhodnutia z väčšej časti neprináša ani následné odôvodnenie, nakolko môže byt vytvorené tak, aby post hoc sedelo na zaujaté, intuitívne, či inak logicky pochybné rozhodnutie. ${ }^{195}$ Takáto obmedzenost' transparentnosti je v kontraste $\mathrm{s}$ informačnou transparentnostou, ktorá z vlastnej podstaty ODR, resp. digitálnej justície, produkuje obrovské množstvo dát, ktoré môže byt̉ následne sprístupnené širokej verejnosti, a to nielen časovo (a vlastne aj miestne) obmedzeným spôsobom, ako to umožňuje otvorený súd. ${ }^{196}$ Susskind záverom uznáva, že ODR síce bude predstavovat zásah do transparentnosti $\mathrm{v}$ reálnom čase, avšak na úkor zvýšenej informačnej transparentnosti, ktorá má podl’a všetkého väčší potenciál pre zaistenie verejnej kontroly výkonu súdnej moci. Tento záver d’alej rozširuje o názor, že zavedenie, resp.

\footnotetext{
${ }^{194}$ Ibid., s. 197.

${ }^{195}$ K sudcovskému rozhodovaniu na základe nelogických postupov, resp. na základe prvotnej „intuície“ vid" Hutcheson, J. Judgment Intuitive The Function of the Hunch in Judicial Decision. Cornell Law Review [online]. 1929, č. 3. https://scholarship.law.cornell.edu/cgi/ viewcontent.cgi? article $=1282 \&$ context $=\mathrm{clr}$

${ }^{196}$ Susskind. Online courts and the future of justice, s. 199.
} 
uprednostňovanie informačnej transparentnosti povedie $\mathrm{k}$ zvyšovaniu spravodlivosti $\mathrm{v}$ krajinách, kde je $\mathrm{v}$ súčasnosti nízka miera efektivity a hlavne nezávislosti justície. ${ }^{197}$ Takéto závery samozrejme už trochu posúvajú hranice toho, čo môžeme rozumne očakávat od takéhoto prístupu k súdnym pojednávaniam. No rozhodne je možné sa stotožnit s autorovým záverom, že existuje viacero prístupov $\mathrm{k}$ transparentnosti a posilnenie jedného (informačná transparentnost') na úkor druhého (transparentnost' v reálnom čase), je nevyhnutné, avšak v konečnom dôsledku sa môže jednat̉ o generálne zlepšenie, minimálne transparentnosti a v jej dôsledku aj výkonu spravodlivosti ako takého.

I ked’ sa táto práca nevenuje bližšej technickej implementácii algoritmov $\mathrm{v}$ rozhodovacích systémoch, je zrejmé, že verejnost', tak ako ju vnímame dnes ( $\mathrm{v}$ podstate zhodne so Susskindovou transparentnostou $\mathrm{v}$ reálnom čase), nebude možné zabezpečit. Znamená to, že musíme túto kapitolu uzavriet $s$ tým, že nie je možné zaistit tento aspekt pre plne automatizované systémy? Nie nutne. Ako vyplynulo z analýzy v úvode tejto kapitoly, úloha tohto aspektu je dvojaká. Má v prvom rade zaistit ochranu jedinca pred zneužívaním súdnej moci formou verejnej kontroly, ktorá má okrem toho prispiet aj $\mathrm{k}$ rozšíreniu všeobecného povedomia o činnosti súdov a fungovaní justície. ${ }^{198}$ Klúčovým aspektom je z viacerých dôvodov možnoste verejnej kontroly. Ak by sme v prospech rozšírenej verejnej kontroly boli ochotní opustit podmienku verejnosti, je možné zosúladit automatizáciu aj $s$ aspektom verejnosti konania a vynesenia rozsudku. Je však samozrejmé,

${ }^{197}$ Ibid., s. 301.

${ }^{198}$ Na tomto mieste je vhodné pre úplnost' uviest', že Susskind ako jeden z aspektov verejnosti (a ústnosti, o ktorých pojednáva spoločne) uvádza aj určitú satisfakciu, ktorej sa vítaznej strane má dostat verejným vyhlásením, že protistrana je na vine, či oni nevinný. Sám však tento nárok označuje za vel'mi okrajový, a tiež je možné ho vnímat’ za splnený uverejnením rozsudku, ktorému nič nebráni a zároveň je širšia dostupnoste rozsudkov jednou z primárnych vlastností informačnej transparentnosti. Očakávanie tejto satisfakcie býva o to silnejšie vo vysoko profilovaných prípadoch, kedy strana očakáva hlavne to, že bude vnímaná ako nevinná hlavne širokou verejnostou. Túto funkciu v takých prípadoch však už aj dnes zabezpečujú hlavne média, a informovanie o procese ich prostredníctvom prechodom $\mathrm{k}$ automatizovanému rozhodovaniu nie je nijak dotknuté (s výnimkou senzácie chtivých článkov o osobách sudcov, ktoré však tažko prispievajú k plneniu tejto úlohy). Vid' Susskind. Online courts and the future of justice, s. 199 - 200. 
hoci to na prvý pohlad zo Susskindovej definície informačnej transparentnosti tak vypadá, že samotné zavedenie automatizovaného rozhodovania (či akýchkol'vek foriem digitálnej justície) nemusí samo o sebe viest̉ $\mathrm{k}$ zvýšeniu transparentnosti a verejnej kontroly a je niekolko skutočností, na ktoré si treba dávat pri zavádzaní pozor.

Predovšetkým je potrebné absolútne odmietnut akékolvek účelné skrývanie rozhodovacích algoritmov a vlastne akéhokolvek technického aspektu systému. Pre zaistenie transparentnosti a verejnej kontroly výkonu (automatizovanej) súdnej moci je potrebné ju vykonávat prostredníctvom otvorených algoritmov . S tým súvisí dôraz na verejne prístupné dáta a trénovací algoritmus. $\mathrm{V}$ porovnaní so súčasným systémom je silnou stránkou digitálnej justície vedlajšie produkovanie obrovského množstva dát a takisto jednoduchšie prístupných rozsudkov. Ich zverejňovanie je nevyhnutné pre zabezpečenie kontroly verejnostou a rovnako dôležité $\mathrm{k}$ tomu aby sa široká verejnost̉ mohla oboznámit s fungovaním justície. Aspekt verejnosti (a pridružene ústnosti) zrejme padne za obet’ plnej automatizácii rozhodovania. Dodržaním vyššie načrtnutých podmienok to však nemusí byt problém pre právo na spravodlivý proces.

\subsection{PRÁVO NA SPRAVODLIVÉ KONANIE}

Posledný aspekt práva na spravodlivý proces, ktorému sa budeme venovat, je zostatková kategória práva na spravodlivý proces - právo na spravodlivé konanie, ktoré na prvý pohl'ad môže vyzerat ako synonymum. To je možno zapríčinené tým, že sama o sebe táto kategória nepredstavuje žiadne individuálne právo a podobne ako právo na spravodlivý proces, aj tento aspekt sa skladá $\mathrm{z}$ d’alších pod-aspektov. Pospíšil výstižne opisuje všetky aspekty, doposial spomínané v tejto práci, ako chrbtovú kost práva na spravodlivý proces a túto kategóriu ako práva, ktoré touto chrbticou nie sú, ale viažu sa $\mathrm{k}$ nej. ${ }^{199}$ Budeme sa preto zaoberat zvlášt každým pod-aspektom, ktorý doktrinálne tvorí súčast tohto práva a pred posunutím sa $\mathrm{k}$ d’alšiemu, bude každý z nich samostatne konfrontovaný s procesom automatizácie. Každý z autorov, ktorých práce boli použité pre doktrinálny vý-

\footnotetext{
${ }^{199}$ Wagnerová et al. Listina základních práv a svobod. Komentár̆., s. 728.
} 
klad aspektov práva na spravodlivý proces, do tejto kategórie radí rôzne práva, preto budú d’alej rozobraté tie, ktoré sa medzi jednotlivými autormi opakovali. ${ }^{200}$

Vela $\mathrm{z}$ aspektov tejto zostatkovej kategórie nebudú procesom automatizácie ovplyvnené. Takto môžeme vnímat napríklad podmienku dôkazných pravidiel. ESL'P nemá žiadne špecifické požiadavky k tomuto aspektu, jediné, čo od členských štátov vyžaduje je, aby boli zavedené (a dodržiavané). ${ }^{201}$ Avšak ani v prípade, kedy by k tomuto nároku bolo pristupované omnoho prísnejšie, nie je dôvod, prečo by sa pre automatizáciu rozhodovania mali menit pravidlá prípustnosti dôkazov pre jednotlivé fázy konania

Čiastočne súvisiacim aspektom, ktorý býva radený pod právo na spravodlivé konanie, je aj rovnost zbraní. Tento aspekt vyžaduje, aby mali všetky strany rovnakú možnost̉ prezentovat svoj prípad, resp. aby niektorá z nich nebola voči zvyšným stranám znevýhodnená, vrátane možnosti oboch strán využívat rovnaké procesné nástroje. ${ }^{202}$ Ako pri predchádzajúcom aspekte dôkazných pravidiel, ani pri tomto nie je dôvod, aby bol pre automatizáciu menený. Súčasné nastavenie rovnosti zbraní je však potrebné mat na pamäti pri vytváraní týchto expertných systémov, tak aby bola preklopená aj do ich procesu a užívatel’ských postupov.

Ďalšou zásadou $\mathrm{v}$ tejto obšírnej kategórii je kontradiktórnost̉ konania. Toto právo podla Harrisa spočíva najmä v možnosti účastníka mat vedomie o, a mat možnost vyjadrit sa $\mathrm{k}$, všetkým dôkazom a relevantným procesným krokom protistrany. ${ }^{203}$ Tento aspekt sa dá rozobrat do dvoch jeho súčastí. Predovšetkým je to otázka súčasného procesného nastavenia tohto aspektu, ktoré, ako vyplynulo z našej počiatočnej analýzy, má nejaké doktrinálne

\footnotetext{
${ }^{200} \mathrm{~V}$ tejto časti budem primárne čerpat z komentárovej literatúry k Dohovoru, nakolko je výklad Listiny v týchto dielčich aspektoch prakticky identický, a Dohovor má potom širšiu aplikovatel'nost'. Niektoré z aspektov, ktoré sem radia niektorý autori už boli rozobraté vyššie, ako napríklad verejnost'. Pre potreby tejto práce sú také aspekty vnímané ako samostatné, a logicky o nich už nebude v tejto časti pojednané.

${ }^{201}$ Harris, O’Boyle, Warbrick. Law of the European Convention on Human Rights, s. 256.

${ }^{202}$ Ibid., s. 251.

${ }^{203}$ Ibid., s. 254.
} 
chápanie. Z tohto záveru je následne potrebné postupovat podobne ako pri dôkazných pravidlách, nakol'ko nie je dôvod sa domnievat', že by sa automatizácia procesu akýmkolvek spôsobom dotkla možnosti strán oboznámit sa s uplatňovanými dôkazmi či postupmi. Respektíve, zrejme nie spôsobom, ktorý by zasahoval do tohto aspektu tak, ako o ňom uvažujeme dnes. Tu však do hry prichádza druhá optika, ktorou treba posúdit tento problém a tou je technický charakter tohto problému, ktorý so sebou môže priniest' nové problémy. Ako poznamenáva Harris, toto právo má slúžit $\mathrm{k}$ adresovaniu jednotlivých úkonov a dôkazov skôr, než sú posúdené sudcom a zvážené ako jeden $\mathrm{z}$ bodov rozhodnutia. To má za účel ovplyvňovanie rozhodnutia $\mathrm{v}$ prospech strany, ktorej toto právo náleží. ${ }^{204}$ Takéto očakávania nás dostávajú naspät $\mathrm{k}$ otázke transparentnosti, resp. $\mathrm{k}$ otázke vytvárania modelov fungovania rozhodovacích algoritmov, za účelom predchádzania problémom „black box“ algoritmov, ako o tom uvažuje Mittelstadt et al. ${ }^{205}$ Tí navrhovali vytváranie aproximatívnych modelov fungovania algoritmov, ktoré by mali plnit primárne edukačnú funkciu, teda oboznamovat" „konečných užívatel’ov“ s ich fungovaním. Transparentnost systémov hrá rozhodujúcu rolu aj pre zaistenie adverzárnosti, kedy strany potrebujú (aspoň aproximatívnu) znalost fungovania rozhodovacieho systému do takej miery, aby podla toho mohli upravit prácu s dôkazmi a argumentami protistrany, resp. celkovo svoju procesnú stratégiu.

Aspektom, ktorý si bude vyžadovat samostatné posúdenie, je však rozhodne právo na odôvodnené rozhodnutie súdu. Z pohl'adu ESL’P je dôvodom pre existenciu povinnosti odôvodneného rozhodnutia možnost strán zvážit a využit dostupné opravné prostriedky. Za týmto účelom musí byt rozsudok odôvodnený „dostatočne jasne“, zároveň však ESL'P národným úpravám (a súdom) ponecháva vel'ký priestor na uváženie, čo to je „dostatočne" odôvodnený rozsudok, resp. na rozhodnutie o obsahu a štruktúre odôvodnení. ${ }^{206}$ Ako d’alšie dôvody pre nevyhnutnost' odôvodnení by podla ESL’P mal byṫ záujem strán na tom, aby sa dozvedeli, že všetky ich argu-

\footnotetext{
204 Ibid.

205 Mittelstadt, Russell, Wachter. Explaining Explanations in AI.

${ }^{206}$ Harris, O’Boyle, Warbrick. Law of the European Convention on Human Rights, s. 268.
} 
menty boli zvážené, že sa s nimi sudca vysporiadal a v neposlednom rade aj existencia širšieho spoločenského záujmu na povedomí o dôvodoch, ktoré vedú $\mathrm{k}$ tej ktorej aplikácii práva. Proporčne k týmto dôvodom by potom mal súd postupovat pri využívaní svojej diškrecie, čo do miery odôvodnenia. Čím podstatnejší argument pre celý prípad, tým väčšia pozornost’ by mu mala byt venovaná pri odôvodňovaní ${ }^{207}$ (a ideálne samozrejme aj pri rozhodovaní, s ktorým by odôvodnenie malo úzko súvisiet'). Rovnako tak musí mat’ odôvodnenie solídny právny základ. ${ }^{208}$

Možnosť českých sudcov pohybovat’ sa v tomto rozhraní pre uváženie, ktoré štátom priznáva ESL’P vo svojej judikatúre, je pevnejšie vymedzená na zákonnej úrovni procesnými predpismi ako zákon 99/1963 Sb., občanský soudní řád a d’alšie podl’a druhu súdnictva, v ktorom sa proces odohráva. ${ }^{209}$ K tomuto bližšiemu určeniu sa potom vyjadril aj Ústavný súd v Náleze III. ÚS 84/94. kde uvádza, že odôvodňovanie súdnych rozhodnutí je jednako znakom demokratickej spoločnosti a jednako má zabránit sudcovskej svojvôli a zaručit predvídatel'nost’ rozhodovania súdov. Z § 157 zákona č. 99/1963 Sb. sa potom dozvedáme, že zdôvodnenie rozhodnutia musí byt vypracované takým spôsobom, aby z neho jasne vyplýval vzt’ah medzi skutkovými zisteniami a úvahami súdu a jeho záverom. ${ }^{210} \mathrm{Z}$ odstavca 2 tohto ustanovenia sa potom môže sudca dozvediet', že v rozsudku, resp. jeho odôvodnení má uviest::

„...čeho se žalobce (navrhovatel) domáhal a z jakých důvodů a jak se ve věci vyjádřil žalovaný (jiný účastník ř́zení), stručně a jasně vyloží, které skutečnosti má prokázány a které nikoliv, o které důkazy opřel svá skutková zjištění a jakými úvahami se při hodnocení důkazů řídil, proč neprovedl i další důkazy, jaký učinil závěr

\footnotetext{
${ }^{207}$ Ibid.

208 Ibid.

${ }^{209}$ Podla názoru Ústavného súdu, ktorý bude nasledovat v texte, je tento nárok zakotvený primárne na ústavnej úrovni článkom 36 a článkom 1. To je samozrejme názor s ktorým nejde nesúhlasit a uvedené procesné normy z týchto ústavných zakotvení vychádzajú, no bližšie informácie o skutočnej štruktúre a prístupu súdov k odôvodneniam, ktoré sú pre nás $\mathrm{v}$ tomto bode relevantné, môžeme logicky nájsț až na nižšej úrovni.

${ }^{210}$ Molek. Právo na spravedlivý proces, s. 275.
} 
o skutkovém stavu a jak věc posoudil po právní stránce; není př́pustné ze spisu opisovat skutkové přednesy účastníků a provedené důkazy. Soud dbá o to, aby odůvodnění rozsudku bylo přesvědčivé. Odůvodnění uvedené v písemném vyhotovení rozsudku musí být $v$ souladu s vyhlášeným oduvodněním. “

Ako uvádza Harris, jeden z dôvodov pre existenciu odôvodnení je aj dôvod zváženia uplatnenia opravných prostriedkov stranami. ${ }^{211}$ Reflexiou tohto princípu je potom odstavec 4, ktorý uvádza:

„V odůvodnění rozsudku, proti němuž není odvolání př́pustné nebo proti němuž se účastníci odvolání vzdali (§ 207 odst. 1), soud uvede pouze predmět řizení, závěr o skutkovém stavu a stručné právní posouzení věci.“

Toto ustanovenie však zároveň reflektuje aj imperatív, aby odôvodnenia slúžili stranám „pre kontrolu“ toho, že všetky ich argumenty boli súdom zvážené a zároveň, že rozsudok (a v tomto prípade jeho odôvodnenie) má širší spoločenský význam, než len pre strany sporu. ${ }^{212}$

Pospíšil v komentári k Listine jednako súhlasí so základom nároku na odôvodnenie rozsudku $\mathrm{v}$ princípoch demokratického štátu, a to $\mathrm{s}$ argumentáciou, že rozsudkom sa štát dopúšta zásahu do práv jedinca a taký akt musí byt odôvodnený, resp. dotknuté osoby musia byt oboznámené s logickým a právnym základom takéhoto rozhodnutia. ${ }^{213}$

Na prvý pohlad je tento princíp vel'mi podobný vyššie rozoberanej explainable AI a aj ked' je možné si predstavit, že riešenie tohto problému bude mat svoj základ v princípoch explainable AI, nejedná sa o rovnaký koncept. Explainable AI má zaručit všeobecnú transparentnost̉ rozhodova-

\footnotetext{
${ }^{211}$ Harris, O'Boyle, Warbrick. Law of the European Convention on Human Rights, s. 268.

${ }^{212}$ Literatúra zvykne hovorit aj o tom, že odôvodnenie píše sudca nadriadenej inštancii, práve kvôli jeho úlohe $\mathrm{v}$ rámci využívania opravných prostriedkov. Takýto pohlad na odôvodnenia uvádza aj Molek, ktorý poukazuje na to, že historicky mali slúžit odôvodnenia ako kontrola nižších inštancií súdnou mocou, ktorý sa rozvinul v rámci procesu byrokratizácie súdnictva. Z tohto nároku sa však potom podla neho časom stal ludskoprávny nárok na výkon súdnej moci. Preto teda nemôžeme zanedbat' odôvodnenia ani v prípadoch, v ktorých nie je nadradená inštancia. Vid’ Molek. Právo na spravedlivý proces, s. 276.

${ }^{213}$ Wagnerová et al. Listina základních práv a svobod. Komentár̆., s. 743.
} 
cieho algoritmu, a to tak, aby účastníci sporu vedeli upravit svoj prístup $\mathrm{k}$ procesu a jeho stratégiu. Z tohto konceptu sa potom môže odvíjat zaručenie práva na odôvodnené rozhodnutie, to je však bližšie transparentnosti na individuálnej úrovni jedného rozhodnutia, nie celého algoritmu ako takého.

Otázkou zostáva, či vieme zaručit dostatočné odôvodnenie rozhodnutia tak, ako ho $\mathrm{v}$ súčasnosti očakávame $\mathrm{v}$ rozsudkoch od ludských sudcov. Pokial' nie, či sme schopní príst s riešením síce odlišným od odôvodnení, aké poznáme dnes, no ktoré je stále schopné dodržat nároky a hlavne účel, akému má slúžite. To znamená, že každé rozhodnutie automatizovaného systému musí byt vybavené logickým vysvetlením rozhodnutia, ktoré by malo zahŕňat aj dôkazy, resp. vysvetlenie ich zváženia či odmietnutia a aká váha im bola prisudzovaná a zároveň musí byt toto rozhodnutie odôvodnené právne. ${ }^{214}$

Takéto nároky na odôvodnenia rozhodnutí plynú z nášho súčasného prístupu k rozhodovaniu, ktoré je „’udsko-centrické“. Ak sa chceme posúvat $\mathrm{k}$ technickému riešeniu tohto procesu, je podla autora potrebné pridat ešte jednu podmienku, a to tú, aby takéto rozhodnutia boli ludsky čitatelné (a zrozumitel'né). ${ }^{215}$

Alibistické riešenie, ktoré sa objavuje naprieč touto prácou, teda dostat do celého procesu nejakým spôsobom človeka, $v$ tomto prípade na to, aby napísal odôvodnenie rozsudku, rozhodne nie je cesta, a to nielen $\mathrm{z}$ dôvodu absolútnej tézy tejto práce. Celkovo pochybnosti o tom, ako dobre môže človek rozumiet presnému postupu na mikro úrovni konkrétneho prípa-

${ }^{214}$ Núka sa klasické „francúzske“ sylogistické odôvodňovanie formou „zákon hovorí........preto...........

${ }^{215}$ Finálna podoba rozsudku musí byt opatrená takým rozhodnutím, aby si jeho priamy adresát, teda účastník sporu vedel okamžite premysliet svoj d’alší postup, či sa presvedčit, že nebol na svojich právach skrátený. Dôraz na takýto prístup je pri technickom riešení podstatný, nakolko v súčasnosti je bežné, že systémy (ako napríklad počítačové operačné systémy) produkujú záznamy o činnosti v podobe tzv. dump files, ktoré sú pre ludské oko len náhodným setom znakov. Tieto súbory je však možné skrz proces „interpretácie“ zmenit tak, aby ich podstatná čast bola ludsky čitatel'ná, toto však nie je uspokojivé riešenie pre našu situáciu. Odôvodnenie priložené k rozsudku musí byt bez d’alšieho prístupné všetkým. 
du, ${ }^{216}$ zároveň by sa jednalo o odôvodňovanie post hoc, ktoré je samo o sebe nemiestne, nakol'ko rozsudok má vychádzat' z bodov uvedených v odôvodnení a má čitatel'a previest' procesom, na ktorého konci je rozsudok a nie naopak, vymýšl'at si dôvody, prečo mohol daný rozsudok vzniknút. Z autorovho pohl'adu nie je preto prípustné túto čast’ procesu „outsource-ovat".

V opozícii k tomuto názoru je napríklad Sourdin, ktorá ako jeden z argumentov pre zavedenie robo-sudcov, resp. ako miesto automatizovaných systémov $\mathrm{v}$ súdnej sieni, vidí napríklad práve $\mathrm{v}$ produkovaní konceptov súdnych rozhodnutí, ktoré by následne l’udský sudca vzal a rozpracoval do prijatel'ne odôvodneného plného rozhodnutia. ${ }^{217}$ So Sourdin nemožno než nesúhlasit', a to z pomerne jednoduchého dôvodu - systém, ktorý opisuje, je totiž ,jednoduchý“ judge-supporting systém a nie plne automatizovaný expertný systém. To bol napokon aj argument v rozhodnutí State v Loomis, kde súd uznal za prípustný postup, v ktorom COMPAS generuje (nezáväzné) odporúčanie a následné rozhodnutie ako také, je vynesené l’udským sudcom, s tým, že odôvodnenie rozhodnutia obsahuje rozpravu o nakladaní s odporúčaním COMPASu, v podstate ako s jedným z dôkazov, či argumentom. Ostatne aj Sourdin sama v texte uvádza, že záver automatizovaného systému sudca použije ako základ pre rozhodnutie, ${ }^{218}$ čo rozhodne nemožno považovat za automatizovaný systém v tom zmysle, ako o ňom uvažuje tento článok.

${ }^{216}$ Goldenfein, J. Algorithmic Transparency and Decision-Making Accountability: Thoughts for Buying Machine Learning Algorithms. Rochester, NY: Social Science Research Network, 2019 [cit 27. 2. 2021]. https://papers.ssrn.com/abstract $=3445873$ - nutno dodat', že autor v tomto článku pracuje primárne s black box algoritmamy, ktoré sú pre naše účely neprípustné. Avšak ani pri obecne transparentnom algoritme, ktorého fungovaniu rozumieme, sa nemôžeme domnievat, že sme presne schopný presne zvážit každý bod individuálneho procesu. Eventuálne, k úvahe o podstate algoritmického „premýšlania“ ako vlastnej „sociotechnickej ontológie“, ktorá nie je len mechanizáciou ludského procesu uvažovania, vid’ Dixon-Roman, E., Nyame-Mensah, A., Russell, A. R. Algorithmic Legal Reasoning as Racializing Assemblages. Computational Culture. 2019, no. 7 [cit. 27. 2. 2021]. $\mathrm{http} / / /$ computationalculture.net/algorithmic-legal-reasoning-as-racializing-assemblages/

${ }^{217}$ Sourdin, T. Judge V Robot? Artificial Intelligence and judicial decision-making. University of New South Wales Law Journal [online]. 2018, č. 41, 1114-1133. http://www.unswlawjournal.unsw.edu.au/wp-content/uploads/2018/12/Sourdin.pdf

${ }^{218}$ Ibid., s. 1130. 
Otázkou však stále zostáva, ako pri tejto požiadavke obstoja plne automatizované systémy bez akéhokol’vek „human-in-the-loop“ úskoku. Musíme sa zaoberat' schopnostou expertného systému vyprodukovat taký log svojej činnosti, ktorý by dodržal všetky vyššie uvedené podmienky. Je teda zrejmé, že v tomto bode sa budeme zaoberat’ výhradne technickou stránkou problému.

Ako už bolo naznačené vyššie, tento problém možno rozdelit na dva pod-problémy. Jednako je potrebné zaručit, že daný expertný systém, ktorý má nahradit l’udské rozhodovanie, je schopný vyprodukovat’ dostatočne podrobnú správu o procese, ktorý viedol k danému záveru. Druhý krok, ktorý je ideálne včlenený do toho prvého, no je nutné klást̉ naň zvláštny dôraz, je, aby táto správa vyprodukovaná expertným systémom bola prístupná (tj. zrozumitel’ná), každému priemerne rozumnému človeku.

V zásade potrebujeme od expertného systému zistit, čo ho viedlo k tomu rozhodnutiu, ktoré spravil a tieto dáta potom „preložit“ do bežného jazyka. Možností, ako od algoritmu zistił základy jeho rozhodnutia, je samozrejme celý rad. Stále sa jedná o vel'mi aktuálnu debatu na poli počítačovej vedy, ktorá má d’aleko od svojho konca. Vo svojej práci o transparentnosti algoritmických modelov Waltl s Voglom ako možné riešenie zistovania jednotlivých faktorov, ktoré viedli k algoritmickému rozhodnutiu, volia cestu, ktorá využíva obrovskú výpočtovú silu, ktorú majú „robo-sudcovia“ k dispozícii. Po vydaní originálneho rozhodnutia, ktoré má byṫ konečným, začne systém postupne menit jednotlivé vstupné faktory a vzájomne ich kombinovat. Z týchto zmenených čiastkových rozhodnutí následne pripraví štatistický model, z ktorého je neskôr možné zistit váhu jednotlivých vstupných bodov pôvodného rozhodnutia. ${ }^{219}$

Ďalšiu z mnohých možností riešenia problému vysvetl'ovania individuálnych záverov algoritmického procesu prinášajú aj Ribeiro et al., ktorý okrem iného kladú dôraz práve na interpretovatel'nost'. Podobne ako predchádzajúce riešenie, aj Ribeiro et al. navrhujú využit’ výpočtové kapacity

${ }^{219}$ Vogl, R., Waltl, B. Increasing Transparency in Algorithmic- Decision-Making with Explainable AI [online]. Stanford Law School [cit 27. 2. 2021]. https://law.stanford.edu/publications/increasing-transparency-in-algorithmic-decision-making-with-explainable-ai/ 
expertných systémov a to za použitia druhého algoritmu (tzv. LIME), ktorého jedinou úlohou je vytvorenie aproximatívneho modelu, tentokrát však nie globálne pre celý algoritmus, ale pre konkrétnu situáciu. Nimi predstavený algoritmus vyberá a užívatel'ovi prezentuje jednotlivé body (resp. vstupné faktory), ktoré majú tomuto užívatel'ovi pomôct pochopit kauzálny vztah medzi údajmi na vstupe a algoritmickým záverom. ${ }^{20}$

Výsledky týchto postupov sú rozhodne informatívne a výskumníkom v oblasti počítačovej vedy dozaista poskytujú užitočný vhl'ad do dôvodu za jednotlivými rozhodnutiami. Ba čo viac, takéto závery nám zrejme sú schopné prezradit všetky informácie, ktoré by prijatel’né odôvodnenie rozsudku podl’a ESL'P malo obsahovat. Takýto aproximatívny model predsa vyjadruje vztah medzi jednotlivými vstupmi, ktoré sú v tejto situácii reprezentované argumentami strán ako aj dôkaznými materiálmi a celý proces je nutne naviazaný na existujúce právne normy, ktorých uplatnenie by sa odrazilo aj vo výsledku takéhoto interpretačného modelu. Takéto výsledky však sami o sebe nespíňajú ani $\mathrm{z}$ d’aleka nárok na to, aby boli všeobecne pochopitel’né každým priemerne inteligentným človekom. ${ }^{221}$

$\mathrm{V}$ tejto fáze odôvodňovania sme $\mathrm{v}$ zásade preklenuli oba problémy, ktoré boli uvádzané začiatkom tejto časti, pri zvažovaní presunutia povinnosti odôvodnit rozhodnutie na človeka. Vieme totiž ako systém $\mathrm{k}$ rozhodnutiu dospel a vodstate by stačilo tieto informácie prepísat do nejakej prijatel'nejšej formy než je $\mathrm{x}^{1} \in\{0,1\}^{\mathrm{d}}$. I ked' takto odpadajú námietky voči inklúzii človeka do tohto procesu z úvodu tejto časti, stále pretrváva naša téza, že hl'adáme možnost̉ plnej automatizácie. Táto druhá čast', teda vytváranie reálneho textu odôvodnenia, v nejakej prijatel’nej forme, by však mohla mat taktiež technické riešenie.

\footnotetext{
${ }^{220}$ Ribeiro, M. T., Singh, S., Guestrin, C. "Why Should I Trust You?": Explaining the Predictions of Any Classifier. arXiv:1602.04938 [cs, stat]. 2016 [cit 27. 2. 2021]. http:// arxiv.org/abs/1602.04938

${ }^{221}$ Príkladom, posledný spomínaný algoritmus LIME, ktorého autori si zakladali na interpretovatel’nosti výsledku a možnosti jeho reprezentácie „pre ludí“, ako výsledok takejto snahy v prípade spracovania textu (na rozdiel od obrázkovej klasifikácie, na ktorú je ich algoritmus tiež použitel'ný), považujú binárny slovný vektor, reprezentovaný interpretovatel'ným výsledkom vo forme $\mathrm{x}^{1} \in\{0,1\}^{\mathrm{d}^{\prime}}$.
} 
Tým jednoduchším avšak výrazne menej univerzálnym, by mohlo byt používanie formulárových odpovedí. Tie by mohli automaticky preberat hodnoty aproximatívnych algoritmov a dopíňat ich na vopred určené miesta vo formulári. Na jednej strane by sme tým rozhodne prišli o mnoho zaujímavých a kritických vstupov, či variácií no na druhej strane je nespochybnitel’ný nárast právnej istoty. Zavedenie takéhoto postupu ju však tažko predstavitel’né, nakol'ko by si vyžadovalo vytvorenie typológie všetkých prípadov a následné vytvorenie formulárov pre každý z nich, čo by bola zrejme náročná úloha pri nepredvídatel’nosti života a právnych problémov, ktoré prináša.

Druhým, trochu odvážnejším prístupom, by mohlo byt’ využitie automatizácie aj na túto úlohu. Obdobné snahy v súčasnosti vyvíja spoločnost' OpenAI, so svojou rodinou Generative Pre-trained Transformer (GPT) algoritmov, ktorých účelom je produkovanie textu, ktorý by mal byt na nerozpoznanie od l'udských autorov. ${ }^{222,223}$

GPT vznikol obdobným spôsobom, aký už bol načrtnutý začiatkom práce, algoritmu bol predstavený obrovský textový dataset, na ktorom bol systém „natrénovaný“. V závislosti na úlohe ${ }^{224}$ sú mu dodatočne poskytnuté d’alšie údaje a vstupy, ktoré majú dopĺn̆at kontext generovaného textu či celej zadanej úlohy („fine tuning“ proces). ${ }^{225}$

Samozrejme úlohou tohto systému nikdy nebolo produkovanie rozsudkov, resp. odôvodnení, no v súčasnosti sa nezdá byt̉ až tak absurdnou predstavou určitá mutácia GPT algoritmu, ktorá je natrénovaná na textoch roz-

${ }^{222}$ Informácie o projektoch, ktoré využívajú GPT algoritmy sú dostupné na https://openai.com/projects/

${ }^{223}$ Pre posúdenie úrovne textu poslednej verzie algoritmu (GPT-3) odkazujem čitatela na článok: GPT-3. A robot wrote this entire article. Are you scared yet, human? | GPT-3 [online]. the Guardian. 8. 9. 2020 [cit 28. 2. 2021]. http://www.theguardian.com/commentisfree/2020/sep/08/robot-wrote-this-article-gpt-3

${ }^{224}$ Posledná verzia algoritmu okrem generovania textu zvláda aj iné textové úlohy, ako napríklad vyhladávanie podla kontextu, a nie klúčových slov. Pre demonštráciu tejto funkcie vid' https://openai.com/blog/openai-api/

${ }^{225}$ Brown, T. B. et al. Language Models are Few-Shot Learners. arXiv:2005.14165 [cs]. 2020 [cit 28. 2. 2021]. http://arxiv.org/abs/2005.14165 
sudkov a za svoje vstupné parametre si berie výstup aproximatívneho algoritmu tak, aby výsledkom bolo slovné odôvodnenie.

Celý opísaný systém je samozrejme vel'mi kostrbatý a záverom nemá byt uznanie, že problém odôvodňovania možno považovat za vyriešený. Táto čast̉ mala skôr slúžit ako počiatočný exkurz do tohto problému a jeho možných technických riešení, ktoré sú v súčasnosti v nedohl'adne. Akákol'vek cesta bude v budúcnosti zvolená pre riešenie tohto problému, je potrebné mat’ na pamäti, že odôvodnenia sú jednako nevyhnutnou súčastou (automatizovaných) rozhodnutí a to $\mathrm{v}$ takej forme, ktorá širokej verejnosti jasne komunikuje logickú postupnost̉ rozhodnutia, váhu prisúdenú jednotlivým dôkazom a argumentom ako aj jeho (korektný) právny základ.

Pohl’ad na obsah práva na spravodlivé konanie sa naprieč literatúrou líši a každý z autorov v tomto aspekte číta určité právo, ktoré v ňom naopak ostatní nevidia, či ho možno nepovažujú za natol’ko dôležité, aby sa ním d’alej zaoberali. Táto čast’ preto rozobrala iba taký súbor práv, ktoré sú súčastou práva na spravodlivý proces, na ktorom sa zhodlo zároveň viacero autorov. Autor predpokladá, že tie práva, ktoré táto kapitola rozoberala, tvoria nielen doktrinálny výklad obsahu tohto práva, ale zároveň sú aj jeho najpodstatnejšími súčastami. Navyše, mnohé d’alšie autormi spomínané práva môžu byt’ nejakým spôsobom adresované v rámci predchádzajúceho rozboru a mnohé d’alšie jednoducho nebudú nijak ovplyvnené automatizáciou. $^{226}$ Harris napríklad ako jeden $\mathrm{z}$ aspektov včlenených do práva na spravodlivé konanie uvádza právo na dôsledné preskúmanie prípadu. ${ }^{227}$ Tento nárok by nás vo svojej konfrontácii s automatizáciou v zásade vrátil k už prejednaným otázkam algoritmickej transparentnosti a odôvodneniam rozhodnutí.

\footnotetext{
${ }^{226} \mathrm{~K}$ právam neovplyvneným automatizáciou ako príklad Harrisova zásada res iudicata, alebo zákaz retroaktivity v neprospech obvineného, či prezumpcia neviny, vid: Harris, O'Boyle, Warbrick. Law of the European Convention on Human Rights, s. 255-270. U práv, ktoré možno označit za také, ktoré automatizáciou nebudú ovplyvnené sa vo vel'kej miere jedná o zákonné nároky na justíciu ako takú, a nie o také, ktoré sa vztahujú priamo na priebeh procesu.

${ }^{227}$ Ibid., s. 267.
} 
Záver tejto časti vlastne zostáva mierne neuspokojivý. Ostáva určité množstvo práv, ktoré sa v tomto aspekte môžu objavit a neboli v tejto práci adresované a takisto pri určitých zložkách, ako napríklad nárok na odôvodnené súdne rozhodnutia, s ohl'adom na súčasný stav techniky je možné ich riešenie skôr len naznačit

Takéto naznačené riešenie však môže byt pre potreby tohto článku dostačujúce, pretože to znamená, že sa nám nepodarilo identifikovat žiadnu absolútnu prekážku zosúladenia práva na spravodlivý proces, resp. v tejto časti práva na spravodlivé konanie a automatizácie rozhodovacích procesov. Takéto naznačenie možného riešenia je tiež vhodné z toho dôvodu, že jasne identifikuje body, ktorých by sa mali budúce riešenia držat a upriamuje pozornost' na niektoré nevyhnutné podmienky, ako napríklad zrozumitel'nost' odôvodnenia, na ktoré je pri vytváraní expertných systémov potrebné sa zamerat.

Identifikácia takýchto fokálnych bodov je vel’mi užitočná pre nasledujúcu kapitolu práce, v ktorej sa budeme venovat práve úprave legislatívy, resp. výberu rôznych bodov práva na spravodlivý proces, ktorým je potrebné venovat zvláštnu pozornost’ pri zavádzaní expertných systémov v súdnictve.

\subsection{ZHRNUTIE}

V tejto časti článku, ktorá je jej nosnou častou, sme sa zaoberali jednotlivými aspektami práv na spravodlivý proces, ktoré sme vyššie identifikovali ako doktrinálne uznané. To samozrejme neznamená, že toto pojednanie bolo vyčerpávajúcim, nakol'ko právo na spravodlivý proces je svojím obsahom omnoho obšírnejšie, než je možné v rozsahu článku pokryt'. Zároveň však mnoho z aspektov tohto práva, resp. rôznych bodov, ktorými sa mnohí autori vo svojich výkladoch zaoberajú, jednoducho neposkytuje žiadny 
priestor pre zásah procesu automatizácie a ak má dôjsţ $\mathrm{k}$ ich zmene, nebude to $\mathrm{z}$ tohto dôvodu. ${ }^{228}$

Ako prvým sme sa $\mathrm{v}$ tejto práci zaoberali aspektom včasnosti, ktorý je potrebné vnímat̉ naprieč celým súdnym konaním už od včasného zahájenia, preto sme tento aspekt zaradili ešte pred právo na prístup k súdu. Včasnost', resp. nenaplnenie tejto požiadavky, sa stáva pomaly už folklórom a to nie len v Čechách, ale ako vyplýva z judikatúry a štatistík jednotlivých stažností u ESL'P, ktorý tento problém pri každej príležitosti nálepkuje ako systémový, je zrejmé, že s nedostatkom včasnosti zápasia krajiny naprieč Európou.

$\mathrm{Z}$ pohl'adu štúdií, ktoré boli $\mathrm{v}$ tejto časti rozobraté, je možné tento problém rozdelit na dve zložky. Za prvé sú to prietahy na strane účastníkov, u ktorých sme dospeli k záveru, že nad nejaké úvahy o formulárových žalobách, resp. procesoch je táto oblast̉ skôr nezasiahnutá, to však pre nás znamená pozitívny výsledok, nakolkko automatizácia nezhoršuje tento, už tak neblahý, stav.

Druhá zložka tohto problému je na strane sudcov. Podla štúdií uvedených v tejto časti, najväčšiu čast̉ procesu zaberá práve ich rozhodovanie, spolu s vynášaním jednotlivých procesných rozhodnutí.

V tomto ohlade je teda zavádzanie automatizácie málo problematické, nakol'ko strojové procesy sú rýchlejšie a môžu spracovávat väčšie množstvo údajov. $\mathrm{V}$ podstate sú variáciou na jedno z najzákladnejších riešení tohto stavu - navýšenie počtu sudcov. Za predpokladu korektnej technickej implementácie nie je požiadavka na včasnost̉ súdneho konania prekážkou zavedenia automatizácie.

\footnotetext{
${ }^{228}$ Potom ešte existuje tretia, podstatne menšia skupina aspektov, ktoré niektorý autori radia medzi právo na spravodlivý proces, resp. presnejšie, sa nimi zaoberajú v rámci práva na spravodlivý proces, ako je napríklad právo na odškodnenie za chybné rozhodnutie/postup. U tohto práva nemôžeme a priori vylúčit ovplyvnenie automatizáciou, otázka ktorú však táto situácia vznáša nie je procesného charakteru, resp. priamo nesúvisí so súdnym procesom a rozhodovaním $\mathrm{v}$ ňom, čo sú body ktorými sme sa $\mathrm{v}$ tejto práci zaoberali. Otázke zodpovednosti za rozhodnutia expertných systémov sa určite stojí zato venovat, no vhodnejším miestom než táto práca je $\mathrm{k}$ tomu rozbor zodpovednosti automatizovaných systémov/AI. Otázky zodpovednosti takýchto systémov sú velmi širokou témou a zaslúžia si samostatné pojednanie.
} 
Ďalším aspektom, ktorým sme sa po včasnosti zaoberali, bolo právo na prístup $\mathrm{k}$ súdu. $\mathrm{V}$ teórii sa problémy, ktorým v súčasnosti toto právo čelí, delia na dve skupiny. Tou prvou sú problémy právne a tou druhou problémy spoločenské. Ak však pripustíme, že prekážky prístupu $\mathrm{k}$ súdu, ktoré sa v systéme spravodlivosti v súčasnosti nachádzajú, sú prípustné, potom by na právne problémy nemala mat automatizácia negatívny dopad. Možno predpokladat menší pozitívny dopad napr. v sprehl’adnení procesu, a teda odstránení inštitucionálnych prekážok. No aj bez úvah o možnostiach zlepšenia by tu nemal byt problém. Otázkou, ktorú sme museli posudzovat bližšie, je problém digitálneho vylúčenia, no ako sa ukázalo, s ohl’adom na digitálnu gramotnost naprieč Európou, ktorá je navyše stále na vzostupe, sa skôr nejedná o tak pálčivý problém ako by sa mohlo zdat. Navyše , ako navrhuje napríklad Susskind, existuje niekolko riešení, ktoré by predchádzali takémuto vylúčeniu. $V$ zásade sa celá otázka viaže na spôsob akou formou, a moment, v ktorom bude automatizácia vstupovat do konania. Pri sociálnych aspektoch tohto problému, ktorým je aj vylúčenie, však hrá silnú rolu predpokladaná väčšia prístupnost práva a súdnictva všeobecne. Spolu s faktom, že ani v súčasnosti nie je súdny proces tak úplne prístupný všetkým bez určitej asistencie $\mathrm{v}$ podobe advokáta, nemožno tento problém považovat za absolútnu prekážku. Pri zvyšných otázkach, ktorým sme sa v tomto bode venovali, sa nám nepodarilo identifikovat potencionálny problém pri automatizácii, resp. ich účel, ako je to napríklad pri súdnych poplatkoch. Jednoducho nemá nijak závažnú spojitosṫ s procesmi, ktoré by mali byt automatizované. Preto ak je správne ustrážený problém možného vylúčenia niektorých skupín, ani právo na prístup $\mathrm{k}$ súdu by nemalo byt negatívne ovplyvnené automatizáciou.

V nadväzujúcej kapitole bola rozobratá spojená otázka práva na nezávislý a nestranný súd, ktorý sme $\mathrm{v}$ duchu doktrinálneho prístupu $\mathrm{k}$ tomuto problému spracovávali spoločne. Táto otázka predstavuje zatial asi najkomplexnejší problém pre budúcu automatizáciu rozhodovacích procesov. Tieto dva nároky na spravodlivý proces nás totižto stavajú hned’ pred celý rad problémov, ako právnych, tak technických. 
Problém nezávislého súdu je vo svetle doktrinálneho výkladu tohto aspektu potrebné chápat ako otázku fungovania súdu, ktorý je nezávislý ako na zvyšných zložkách štátnej moci, tak aj inštitucionálne. Každý jednotlivý sudca je vo svojom rozhodovaní nezávislý na vplyvoch prichádzajúcich "zvnútra“ od súdnych funkcionárov či nadriadených inštancií. Tu do hry vstupujú najmä obavy o opätovné vymenovanie či kariérny postup. Asi si len tažko predstavit expertný systém, ktorý by pri svojom rozhodovaní bol zatažený takýmito „ludskými“ myšlienkami a pri našej súčasnej interpretácii tohto aspektu ho môžeme vnímat ako taký, ktorý nie je prekážkou automatizácie.

Zaujímavejším, resp. komplexnejším, je problém nezaujatého súdu. Tento by mal, zjednodušene povedané, zaručit, že sudca nemá utvorený názor na spor ešte pred jeho zahájením. Na ten je možné nazerat optikou viacerých klasifikácii. Pomocou subjektívneho a objektívneho testu, alebo funkčného a osobného, pričom sú si tieto dva prístupy do vel'kej miery podobné. Pri objektívnom, resp. funkčnom prístupe, je potrebné skúmat, či nedochádza $\mathrm{k}$ zaujatosti sudcu cez jeho predchádzajúcu činnost', ako napríklad súdenie danej veci v predchádzajúcej inštancii a podobne. Pri subjektívnej alebo osobnej zaujatosti sa skúma akýkolvek osobný dôvod sudcu $\mathrm{k}$ zaujatosti, ako napríklad jeho predchádzajúce výroky či osobné vztahy k účastníkom. Tu sa opät môže zdat,, že takéto „’udské“ nazeranie na tento problém nie je úplne vlastné expertným systémom, napokon v momente, ked' bude stroj schopný držat' osobné antipatie voči l'ud’om, budeme mat pravdepodobne iné problémy.

Tu však prichádza do hry technická stránka celého tohoto problému. Podla všetkého sa asi nemusíme obávat, že by expertný systém rozhodol nezákonne jedným či druhým spôsobom, pretože za tým vidí kariérny postup, algoritmická zaujatost je však stále problémom, ktorý je momentálne živo riešený medzi odborníkmi na počítačové vedy. Ako bolo opísané v texte, $\mathrm{k}$ takémuto nesprávne fungujúcemu stroju, resp. zaujatému, môžeme dospiet hned' niekol'kými spôsobmi, v závislosti od spôsobu ich vzniku. $\mathrm{V}$ prvom rade tu máme vytváranie rozhodnutí na základe chybných dát 
a d’alším, nie menej problematickým, je „prenášanie“ (v lepšom prípade) nevedomej zaujatosti tvorcov algoritmu na jeho fungovanie.

Technické obory sa zaoberajú rôznymi prístupmi ako tento problém odstránit už pri vytváraní systémov, ako napríklad postupovat tak, aby systém jednoducho nemal k dispozícii tie údaje, ktoré by ho k zaujatému rozhodnutiu mohli viest'. Ako bolo však opísané v tejto časti textu, takéto rýchle riešenie zrejme nebude dostatočné, s ohl'adom na l'ud'mi nepredvídatel’nú komplexnost' strojového rozhodovania.

Riešením tejto situácie by mohlo byt predovšetkým prijatie faktu, že zaujatosti $\mathrm{v}$ algoritmickom dizajne nevieme predchádzat, a preto $\mathrm{k}$ nej takto aj pristupovat. To by $\mathrm{v}$ praxi znamenalo zavedenie kontrolných mechanizmov, ako napríklad testovanie systému pred jeho zavedením, spolu s periodicky opakovaným testovaním, ktorého účelom by malo byt odhal'ovanie a následné odstraňovanie takýchto negatívnych javov.

Jedná sa o prvý z aspektov, ktorý by sme mohli označit ako skutočne problematický. Pri správnom nastavení kontrolných procesov sa však nejedná o absolútnu prekážku automatizácie rozhodovacích procesov.

Predposlednou otázkou, ktorú táto práca riešila, bolo právo na verejné konanie, ktorá opät rozširuje problematickost’ zavádzania automatizácie. Tak ako subjektívne a objektívne testy predchádzajúceho problému, aj právo na verejné konanie je vysvetl’ované výsostne s ohl'adom na súčasné formy súdneho konania. V podstate môžeme vyslovit’ záver, že spôsob , akým k nemu pristupujeme teraz, v zásade nie je zlučitel’ný s právom na spravodlivý proces. Autor je však toho názoru, že toto ešte vždy nemusí znamenat absolútny koniec automatizácie v súdnych procesoch. Ako bolo rozobraté $\mathrm{v}$ texte, táto podmienka bola zavedená najmä za účelom umožnenia verejnej kontroly výkonu súdnej moci a sekundárne za účelom zvyšovania povedomia širokej verejnosti o práve.

V prostredí automatizovaného rozhodovania je však možné tieto účely zaručit prostredníctvom transparentnosti, ktorá musí absolútne vylúčit akékol’vek skrývanie sa za obchodné tajomstvo a podobne. Transparentnost' automatizovaných rozhodovacích systémov je zároveň významný faktor pre zvýšenie ich dôveryhodnosti. S ohl'adom na expertné systémy sa vyskytujú 
dva druhy transparentnosti, jedným je transparentnost’ v reálnom čase a druhým je informačná transparentnost'. Práve transparentnost’ v reálnom čase je predstavovaná našim súčasným prístupom $\mathrm{k}$ verejnosti konania. S ohl'adom na naše možnosti, obzvlášt potom na možnosti, ktoré súdnictvu poskytuje obecná digitalizácia justície, je takýto druh transparentnosti značne neefektívny pre zabezpečenie kontroly výkonu súdnej moci, či už zo strany samotných účastníkov procesu alebo zo strany širokej verejnosti. Samotná skutočnost', že je možné byt’ prítomný pri procese počas jeho priebehu, nám totiž úplne nezaručuje skutočný prehl'ad o rozhodovacom procese. Naproti tomu stojí informačná transparentnost', ktorej nedostatkom trpí súčasný prístup k súdnictvu. Informačná transparentnost̉ je, vel’mi zjednodušene, prístupom v rámci ktorého sa kladie dôraz na zverejnenie čo najväčšieho množstva informácii v čo najvhodnejšej forme a vo vhodnom časovom horizonte. To môže zahŕňat’ všetko od jednoduchého včasného uverejnenia informácie o konaní, cez verejne dostupné a podrobné odôvodnenia rozsudkov až po plné sprístupnenie rozhodovacích algoritmov a všetkých informácii o ňom a procese jeho tvorby. Takýto prístup stojí jednako na myšlienke, že možnost’ verejnej kontroly má náležat každému, a preto sa nemá obmedzovat’ len na l’udí, ktorí sú schopní sa v presnom momente nachádzat na presnom mieste - teda v súdnej sieni, počas procesu. Zároveň tento druh transparentnosti stojí na myšlienke, že skutočnú kontrolu procesu je možné vykonávat' len za predpokladu, že disponujeme kompletnými a podrobnými informáciami o ňom.

Je to práve tento dôvod, prečo je aspekt verejnosti problematickým. Zavádzaním automatizovaného rozhodovania by sme zrejme museli upustit od verejnosti súdneho procesu v tradičnom zmysle. Takýto postup však na druhú stranu znamená posun od transparentnosti $v$ reálnom čase $\mathrm{k}$ informačnej transparentnosti. Otázkou ostáva, či budeme tento druh transparentnosti schopní nastavit tak, aby mohol vyvážit nedostatok reálnej transparentnosti a tiež, ako by takýto posun bol prijatý širokou verejnostou. Konečne, je to práve široká verejnost', ktorej má byt’ informačná transparentnost’ adresovaná a bez jej prijatia, resp. súčinnosti, stráca svoj význam, 
význam verejnej kontroly, ktorý je jedným z kl’účových aspektov práva na spravodlivý proces.

Posledný aspekt, ktorým sa táto práca zaoberala, je aspekt práva na spravodlivé konanie. Tento je sám o sebe tvorený niekol'kými d’alšími a v zásade viac než určité právo predstavuje zostatkovú kategóriu pre zvyšné podmienky, ktoré kladieme na súdne konanie, ktorých účelom je dopomôct férovosti konania ako celku. Táto kategória je značne obšírna a rôzni autori do nej zároveň zahŕňajú rôzne aspekty. Z jednotlivých zložkových aspektov, ktorými sme sa zaoberali v tejto časti, je najkomplexnejšia problematika práva na odôvodnenie rozsudku.

Riešenie tejto otázky potrebujeme rozložit na dve časti. Prvou je otázka, do akej miery je samotný expertný systém schopný zaznamenat postup procesu a jeho jednotlivých rozhodujúcich faktorov. Sotva budeme vediet’ odôvodnit rozhodnutie, o ktorom v zásade nič nevieme., Druhá čast', ktorou sa musíme v tomto prípade zaoberat a je výrazná práve v prostredí expertných systémov, je zrozumitel'nost' takéhoto rozhodnutia, resp. odôvodnenia. Nie je dostačujúce účastníkom sporu poskytnút čisto „mechanický záznam“ činnosti systému, tento musí byt’ interpretovaný do takej podoby, ktorá je zrozumitel’ná každému priemerne inteligentnému človeku.

Následne boli predstavené niektoré riešenia, ktoré by mohli predstavovat taký postup, ktorý by bol schopný zachovat tento nárok aj v plne automatizovanom súdnom procese. Tento posledný bod rozboru je možné uzavriet’ s tým, že nárok na odôvodnené rozhodnutie nepredstavuje absolútnu prekážku procesu automatizácie. Na druhej strane sa môže jednat o podstatnú relatívnu prekážku, ktorá do podstatnej miery spočíva v technickom riešení daného problému. Táto práca, resp. právo ako také, môže v tomto ohl'ade poskytnút určitý návod na konštrukciu technického riešenia, akým je napríklad absolútna nevyhnutnost̉ poskytovania individualizovaných a zrozumitel’ných odôvodnení záverov.

Počas jednotlivých analýz v tejto práci sme ani v jednom bode neboli konfrontovaní s problémom, ktorý by predstavoval absolútnu prekážku pre zavedenie automatizovaných rozhodovacích systémov z pohl'adu práva na spravodlivý proces. Zároveň je však potrebné klásţ dôraz na mnohé nové 
možné problémy, ktoré so sebou zavádzanie takýchto postupov môže priniest’ a rozhodne nebude úplne bez tažkostí. V nasledujúcej časti práce bude preto čitatel' oboznámený s možnostami, akými by mohlo pozitívne právo prispiet k zníženiu možných negatívnych dopadov užívania expertných systémov a v ideálnej situácii im aj predchádzat̃.

\section{LEGISLATÍVA}

V nasledujúcej časti bude čitatel oboznámený s jestvujúcimi normatívnymi dokumentami, ktoré upravujú využitie expertných systémov. Primárne sa zameriame na dokumenty s geografického prostredia Rady Európy, nakol'ko ako jeden z hlavných dokumentov, ktorý tvoril základ pre výklad práva na spravodlivý proces, bol práve Dohovor ako dokument Rady Európy. Väčšina týchto dokumentov má povahu soft law, či odporúčaní, preto sa podporne pozrieme aj na dokumenty z krajín, ktoré nie sú členmi Rady Európy, či nepoužívajú kontinentálny právny systém, no túto úpravu je možné u nich nájst ako záväzný normatívny predpis.

V nasledujúcej časti bude potom predstavený abstraktný návrh úpravy legislatívy $\mathrm{v}$ oblasti automatizácie súdneho rozhodovania tak, aby bol v súlade s nárokmi na spravodlivý proces. Táto čast̉ prinesie všeobecné odporúčania pre normotvorcov, resp. na základe predchádzajúcej časti práce zdôrazní niektoré závery a fokálne body potencionálnej budúcej úpravy.

\subsection{DE LEGE LATA}

V právnych poriadkoch krajín Rady Európy $\mathrm{v}$ súčasnosti neexistuje žiadny záväzný právny akt, ktorý by sa venoval úprave automatizácie súdneho rozhodovania. To isté $\mathrm{v}$ zásade platí aj na nadnárodnej úrovni, teda $\mathrm{v}$ tomto prípade na úrovni Európskej únie. Otázne je, či tento nedostatok zákonnej úpravy svedčí o presvedčení zákonodarcu, že existujúca právna úprava je dostatočná, alebo o tom, že automatizáciu procesov nevnímajú ako problém, na ktorý sa treba (už) pripravovat.

Ak však nechceme túto čast̉ odbit týmto strohým záverom, ostáva nám ešte niekol'ko možností, resp. (kvazi) normatívnych úprav, ktorými sa môžeme zaoberat. Tou prvou je Nariadenie Európskeho parlamentu a Rady 
2016/679 o ochrane fyzických osôb pri spracúvaní osobných údajov a o vol'nom pohybe takýchto údajov, ktorým sa zrušuje smernica 95/46/ES (všeobecné nariadenie o ochrane údajov) (d’alej tiež „GDPR“ alebo „Nariadenie").

Toto nariadenie sa v oddiele 4, resp. v článku 22, zaoberá profilovaním a automatizovaným rozhodovaním. Tento strohý článok zaručuje osobám, o ktorých bolo (s právnymi účinkami) automatizovane rozhodnuté, či ktoré boli obdobným spôsobom automaticky profilované, niektoré práva, ktorými sme sa inšpirovali už pri úvahách o viac inštančnosti súdneho konania, resp. o procese odvolania voči automatizovaným súdnym rozhodnutiam. Tento článok stojí prevažne na práve na odmietnutie, teda možnosti osoby, o ktorej je rozhodované, odmietnut', aby sa na ňu vztahovalo rozhodnutie, ku ktorému bolo dospeté pomocou automatizovaného procesu. Druhý odsek tohto článku potom uvádza výnimky, kedy nie je možné využit právo na odmietnutie. Aj v takýchto prípadoch však GDPR zdôrazňuje, že je potrebné šetrit práva osôb, o ktorých je rozhodované a to okrem iného aj prostredníctvom práva na l'udský zásah zo strany prevádzkovatel’a. Celkovo GDPR zavádza hned’ niekol'ko možností na zachovanie „human-in-the-loop“ formy procesu.

Okrem modelu vstupu l’udského prvku, ktorý by mohol v našom prípade byt zvažovaný ako podoba inštančnosti, ktorú pri ODR obhajuje aj Susskind, ${ }^{229}$ nájdeme zaujímavé ustanovenia aj mimo vlastného textu GDPR, v preambule tohto dokumentu. Bod 71 preambuly v druhom odstavci kladie dôraz na férové a transparentné spracovávanie dát. $\mathrm{V}$ rámci tohto princípu potom Nariadenie upozorňuje na vol'bu vhodného matematickoštatistického modelu, ustanovenie technických a organizačných procesov a záruk, ktoré majú zaručit, že používané dáta sú správne a to tak, aby boli minimalizované možné chyby v rozhodovaní. Napokon Nariadenie upozorňuje na povinnost’ predchádzat zaujatosti v rozhodovaní a to najmä šetrným a minimálnym narábaním s chránenými atribútmi, teda takými údajmi, ktoré môžu byt dôvodom $\mathrm{k}$ zaujatému rozhodnutiu.

\footnotetext{
${ }^{229}$ Susskind. Online courts and the future of justice, s. 205.
} 
V podstate toto Nariadenie kladie dôraz na zachovanie možnosti l'udského prvku v rozhodovaní, transparentnost', kontrolu procesu a predchádzanie negatívnym či nevhodným zásahom a tiež kladie dôraz na zaujatost’ a jej predchádzanie prostredníctvom princípu „fairness through ignorance“. ${ }^{230}$

Ďalšie dokumenty, ktorými sa $\mathrm{v}$ týchto otázkach môžeme inšpirovat v rámci priestoru Rady Európy, sú odporúčania nižšej právnej sily, a to najmä z dielne High Level Expert Group on Artificial Intelligence (d’alej tiež „Panel“). ${ }^{231}$ Pri posudzovaní týchto dokumentov sa vzd’alujeme ešte viac od expertných systémov v súdnom procese, no výstupy tejto pracovnej skupiny sa všeobecne zaoberajú takými systémami, ktoré majú bud'to nahradit ludskú činnost', či vykonávat činnost' bez ingerencie l’udí, ktorá je svojím procesom či výstupom podobná tej luudskej. Na abstraktnej úrovni, na akej sa väčšina týchto výstupov drží, nám môžu aj tieto dokumenty slúžit ako inšpirácia.

Prvým výstupom činnosti Panelu boli Etické pravidlá pre dôveryhodnú AI. ${ }^{232}$ Týmto dokumentom Európska Komisia deklarovala svoj „humancentric" prístup k vývoju AI a jej zavádzaniu. ${ }^{233}$ Tento prístup však neznamená bezvýhradné zachovávanie „human-in-the-loop“ sytémou, ale zdôrazňuje orientáciu na vytváranie systémov, ktoré budú tvorené „pre ludí“. V našom kontexte by to teda mohlo znamenat kladenie dôrazu na šetrenie práv strán sporu, ktorý by mohol byt takýmto expertným systémom posudzovaný. V úvode samotného dokumentu potom Panel zdôrazňuje tri základné princípy (etického) vytvárania dôveryhodných systémov AI a to a) zákonnost', teda že takto vytvorený systém je v súlade so všetkými platnými zákonmi, b) systém je etický, čiže sleduje etické

\footnotetext{
${ }^{230} \mathrm{~K}$ tomuto a d’alším princípom (algoritmickej) férovosti: Kusner et al. Counterfactual Fairness.

${ }^{231}$ Všeobecné informácie $\mathrm{k}$ tomuto Panelu na: https://ec.europa.eu/digital-single-market/en/ high-level-expert-group-artificial-intelligence

${ }^{232}$ High-level expert group on artificial intelligence. Ethics guidelines for trustworthy AI [online]. Európska komisia. 2019 [cit 01. 03. 2021]. https://ec.europa.eu/digital-single-market/en/news/ethics-guidelines-trustworthy-ai

${ }^{233}$ Anonymous. Communication Artificial Intelligence for Europe [online]. Shaping Europe's digital future - European Commission. 25. 4. 2018 [cit 15. 5. 2020]. https://ec.europa.eu/digital-single-market/en/news/communication-artificial-intelligence-europe
} 
princípy a hodnoty, c) systém je odolný $\mathrm{z}$ technického a sociálneho pohl'adu tak, aby nespôsobil neúmyselnú ujmu. ${ }^{234}$ Bod a), nutná zákonnost’ takéhoto systému, je v zásade automatickým predpokladom pri sudcovskom expertnom systéme. Táto požiadavka fakticky vyplýva aj z nárokov na spravodlivý proces. $^{235}$ Bod b) je trochu problematickejší a to hned' $\mathrm{z}$ viacerých dôvodov. Tento nárok nás tak trochu stavia pred meta-otázku vztahu etiky (morálky) a práva, ktorej riešenie si táto práca rozhodne nekladie za ciel'. Samotný dokument sa k tomuto bodu vyjadruje tak, že právo nie je vždy aktuálne a nie vždy je vhodné na riešenie niektorých problémov a túto medzeru by mala práve suplovat etickost' systému. Navyše, dokument uvádza nemožnost’ ustanovenia všeobecného etického kódexu, a preto je potrebné od systému vyžadovat etické myslenie na abstraktnej úrovni, čo je druhý, tentokrát technologický problém, nakol'ko dokument si predstavuje algoritmizáciu niečoho, čo má byt̉ podla neho nepomenovatel'né a nemožné plne vyjadrit. Meta-právnym problémom je tu následne vyjadrenie, že právo je nedokonalé, resp. niekedy až nevhodné a riešením takejto situácie je etika, čo je dvakrát tak neštastné práve ked' diskutujeme o (spravodlivom) procese.

Naštastie sa po tomto úvode môžeme dočítat o 4 etických princípoch, na ktorých majú takéto systémy stát. Tieto princípy vychádzajú podla samotného dokumentu zo základných práv. Medzi ne Panel zaradil a) rešpektovanie l’udskej autonómie; b) prevencia ujmy; c) spravodlivost’; d) vysvetlitelnost. ${ }^{236}$ Ak uvažujeme nad požiadavkou „etickosti“ takýmto spôsobom, je rozhodne vhodné zvažovat’ tieto pravidlá aj pri d’alšom vytváraní noriem dopadajúcich na oblast’ automatizácie súdneho rozhodovania a zároveň to do vel'kej miery rieši druhý, technický problém algoritmizácie tak abstraktného konceptu, akým je etické uvažovanie bez etický noriem.

\footnotetext{
${ }^{234}$ High-level expert group on artificial intelligence. Ethics guidelines for trustworthy AI, s. 6.

${ }^{235}$ Obecne je požiadavka zákonnosti vo verejnoprávnom uplatnení akejkolvek automatizácie v zásade automatickým predpokladom, tento dokument je však cielený na omnoho širšie publikum, všetkým „zainteresovaným stranám“, od „podnikov po vládne inštitúcie“, preto taký dôraz na tento princíp. Vid’ deklaráciu v: High-level expert group on artificial intelligence. Ethics guidelines for trustworthy AI, s. 7.

${ }^{236}$ Ibid., s. 14.
} 
Posledným navrhovaným bodom je zváženie odolnosti systému. Panel túto požiadavku interpretuje ako takú, ktorá zaručuje, že „Tieto systémy by mali fungovat’ bezpečným, chráneným a spol’ahlivým spôsobom a s ciel’om zabránit’ neúmyselným nepriaznivým účinkom by sa mali navrhnút’ ochranné opatrenia“. ${ }^{237}$

Prvou zložkou tohto bodu je technická odolnost’ a bezpečnost', ktorá má podl'a Panelu zaručit ochranu pred vonkajším útokom, záložný plán, presnost', spol'ahlivost’ a reprodukovatel’nost'. ${ }^{238}$ Táto zložka má podl'a tohto dokumentu zahŕňat aj prevenciu a minimalizáciu ujmy, ktorá je tu podla autora už však trochu redundantná a bola zahrnutá v bode b). Okrem toho zahŕňa ešte transparentnost' a l’udský dohl'ad, ku ktorému panel vel'mi abstraktne uvádza, že je nutné ho nejakým spôsobom zaradit do systému a to v akejkol'vek forme. Okrem „human-in-the-loop“ prístupu je splnením tejto požiadavky aj akýkol’vek iný prístup teda „human-on-the-loop“ alebo „human-in-command“. ${ }^{239} \mathrm{~V}$ závere však dodáva, že miera zahrnutia človeka do procesu by mala byṫ nepriamo úmerná miere testovania, ktoré musí prebehnút pred zahájením prevádzky systému. ${ }^{240}$

Tento dokument tvorí hlavný výstup práce Panelu a nim vyprodukované d'alšie dokumenty už len nadväzujú, či rozvíjajú princípy a body stanovené v tomto dokumente. Aj ked' je rozhodne potrebné zvažovat rôzne celospoločenské iniciatívy, ktoré majú pripravit’ infraštruktúru pre fungovanie takýchto systémov cez narábanie s dátami ${ }^{241}$ alebo vzdelávanie ${ }^{242}$, či pripravit’ priestor pre spoločenské prijatie takýchto systémov, napríklad prostredníctvom riešenia problému digitálneho vylúčenia. ${ }^{243} \mathrm{Z}$ pohl’adu tejto práce sa

\footnotetext{
${ }^{237}$ Ibid., s. 8.

${ }^{238}$ Ibid., s. 17.

${ }^{239}$ K významom jednotlivých pojmov Ibid., s. 19.

240 Ibid.

${ }^{241}$ High-level expert group on artificial intelligence. Policy and investment recommendations for trustworthy AI [online]. Európska komisia. 2019 [cit 01. 03. 2021]. s. 27 - 31. https:// ec.europa.eu/digital-single-market/en/news/policy-and-investment-recommendationstrustworthy-artificial-intelligence

${ }^{242}$ Ibid., s. $31-37$.

${ }^{243}$ Ibid., s. 13.
} 
jedná skôr o sekundárnu legislatívu a iniciatívy a preto im nad’alej nebude venovaný širší priestor.

Nakol'ko sa medzi krajinami Rady Európy nenachádza žiadna norma na zákonnej úrovni ${ }^{244}$, ktorá by sa venovala týmto otázkam, ako posledný bod, pred pristúpením $\mathrm{k}$ druhej, preskriptívnej časti tejto kapitoly, sa pozrieme na Kanadskú úpravu, konkrétne na Nariadenie o Automatizovanom rozhodovaní. $^{245}$

Toto relatívne strohé Nariadenie má vymedzit základ fungovania automatizovaných verejno-právnych rozhodovaní, a tak okrem verejných orgánov dopadá aj na súkromný sektor, na tvorcov týchto expertných systémov. $^{246}$

Ako expertný systém, teda systém, ktorého fungovanie upravuje, vníma toto Nariadenie takú technológiu, ktorá nahrádza, alebo asistuje $\mathrm{v}$ rozhodovacom procese, ktorý za bežných okolností predpokladá l’udský úsudok. ${ }^{247} \mathrm{~V}$ súčasnosti v Kanade takéto systémy nenahrádzajú sudcov, resp. ich uplatnenie nemožno pozorovat vo väčšine sporov, no vel'ké množstvo správnych rozhodnutí, ktoré majú aspoň kvázi-judiciálnu povahu, je vykonaných expertným systémom.

${ }^{244}$ Čitatel’ovi dávam ešte do pozornosti White Paper Európskej komisie „On Artificial Intelligence - A European approach to excellence and trust“, ktorý sa obecne venuje prístupu EÚ k AI a k jej vývoju. Tento dokument vhodne rekapituluje niektoré výhody širokého zavádzania takýchto technológii, ktorých čast̉ sme reflektovali napríklad aj $\mathrm{v}$ pojednaní o práve na prístup $\mathrm{k}$ súdu, nad to sa však dokument už len venuje opakovaniu záverov Panelu a skôr politickým prehláseniam o spolupráci medzi členskými štátmi. Vid’:

https://ec.europa.eu/info/sites/info/files/commission-white-paper-artificial-intelligencefeb2020_en.pdf Podobným dokumentom, vztahujúcim sa bližšie na Českú republiku je potom „Národní strategie umělé inteligence v České republice“, tento dokument však poskytuje rovnako skôr politické prehlásenia a opakuje niektoré body, ktoré sú zahrnuté $\mathrm{v}$ druhom výstupnom dokumente od Panelu, preto sa na tomto mieste tomuto dokumentu nebudeme d’alej venovat. Vid: https://www.vlada.cz/assets/evropske-zalezitosti/umelainteligence/NAIS_kveten_2019.pdf

${ }^{245}$ Secretariat, T. B. of C. Directive on Automated Decision-Making [online]. 5. 2. 2019 [cit 2. 3. 2021]. https://www.tbs-sct.gc.ca/pol/doc-eng.aspx?id $=32592$

${ }^{246}$ Federal Government's Directive on Automated Decision-Making: Considerations and Recommendations | McCarthy Tétrault [online]. [cit 3. 3. 2021]. https://www.mccarthy.ca/ en/insights/blogs/snipits/federal-governments-directive-automated-decision-making-considerations-and-recommendations

${ }^{247}$ Secretariat, T. B. of C. Directive on Automated Decision-Making, Appendix A. 
Asi najrozšírenejším je príklad systému vyvinutého kanadským úradom pre občianstvo a imigráciu (Immigration, Refugees and Citizenship Canada - IRCC). Tento systém využíva zároveň aj prediktívne modely, na základe ktorých následne dochádza k rôznym automatizovaným rozhodnutiam, napríklad pridelenie miesta na ubytovanie pre žiadatel’ov o azyl, či dížku azylu, alebo automaticky označuje „podozrivých“ žiadatel’ov, či ich delí do skupín podla predpokladanej dížky a úspešnosti konania, s čím sú spojené rôzne práva žiadatel'a. ${ }^{248}$

V článku 6 toto Nariadenie predstavuje niekol'ko požiadaviek, ktoré musia takéto automatizované rozhodovacie systémy splnit pred ich širším využívaním. Mnohé z nich sú identické s požiadavkami, ktoré už boli $\mathrm{v}$ tomto texte vyslovené.

Prvou požiadavkou je posúdenie dopadu algoritmického rozhodovania („AIA“), ktoré je potrebné vykonat' pred spustením systému ${ }^{249}$ a v zásade ho môžeme prirovnat' $\mathrm{k}$ požiadavke šetrenia práv jednotlivcov, ktorú zdôrazňoval aj Panel. ${ }^{250}$

Ako druhý bod Nariadenie uvádza transparentnost', ako princíp, do ktorého zahŕňa upozornenie na automatizované rozhodovanie, ktoré však nemusí byṫ individuálne a stačí napríklad upozornenie na stránke príslušného orgánu. Ďalej pod transparentnost̉ zahŕňa aj následné odôvodnenie rozhodnutia, ktoré však tiež nemusí byt’ individualizované a stačí všeobecný popis rozhodovacieho procesu. ${ }^{251}$ Ďalší bod, ktorý je adresovaný skôr orgánu implementujúcemu patričný expertný systém, je zachovanie prístupu. Tým sa rozumie „správne“ licencovanie softvéru a to takým spôsobom, aby k nemu mal príslušný orgán plný prístup bez obmedzenia, rovnako aj ku

\footnotetext{
${ }^{248}$ Molnar, P., Gill, L. Bots at the Gate: A Human Rights Analysis of Automated Decision-Making in Canada's Immigration and Refugee System. 2018 [cit 3. 3. 2021]. https://tspace.library.utoronto.ca/handle/1807/94802 K funkcionalite najmä strany $4-14$.

${ }^{249}$ Secretariat, T. B. of C. Directive on Automated Decision-Making, článok 6.1.

${ }^{250}$ Toto posúdenie potom zaradí daný automatizovaný systém do jednej zo 4 úrovní podla Apendixu B, a od tejto úrovne sa potom odvíjajú niektoré povinnosti podla Apendixu C, ako napríklad úroveň požadovanej peer-review systému.

${ }^{251}$ Ibid., Appendix C.
} 
všetkým jeho komponentom. Na to následne čiastočne nadväzuje posledný bod transparentnosti, ktorým je uverejnenie zdrojového kódu. ${ }^{252}$

Posledným substantívnym bodom tohto článku Nariadenia je „kontrola kvality“ ${ }^{253}$ Prvá zložka tohto bodu sa čiastočne vracia spät k prvej požiadavke na posudzovanie algoritmického dopadu. $\mathrm{V}$ tomto prípade sa však má jednat o testovanie a monitorovanie výsledkov, ktoré má byt posudzované $\mathrm{v}$ rovnakej fáze ako dopad. Toto monitorovanie má pred spustením odsledovat zaujatost systému, rovnako ako aj d’alšie možné negatívne odchýlky od férového rozhodovania. Po predbežnom teste pred spustením, toto Nariadenie vyžaduje aj pravidelné opakované testovanie, ktorého účelom má byt̉ odhalenie takýchto odchýliek. S týmto súvisí aj požiadavka na „peer-review“ systému, ktoré je odstupňované a vyžaduje od kontroly iným vládnym orgánom, cez externé konzultácie až po publikáciu v peer-reviewed odbornom periodiku. ${ }^{254}$

Ďalšou súčastou tohto bodu je zabezpečenie „kvality“ dát, ich presnost', úplnost a vhodnost', a zároveň že sú v súlade s relevantnými kanadskými predpismi o súkromí a ochrane dát.

Poslednou, pre nás zaujímavou požiadavkou tohto bodu, je zaistenie možnosti l’udského zásahu. Tu sa však podobne ako Panel uspokojí s akoukolvek formou, od „human-in-the-loop“ až po „human-on-the-loop“, a aj to $s$ dodatkom „na miestach, kde je to vhodné“.

Ustanovenie d’alej obsahuje vedlajšie požiadavky, ako zaistenie vhodného zaučenia personálu alebo prípravu záložných systémov pre kritickú infraštruktúru.

Nosnou myšlienkou všetkých spomínaných úprav je minimalizácia možného negatívneho dopadu v podobe nespravodlivého rozhodnutia na jednotlivca. Rovnako ako majú tieto dokumenty spoločnú centrálnu myšlienku, aj spôsoby, akými by toho malo byt dosiahnuté, sú si relatívne podobné. Dôraz je kladený najmä na komplexné posúdenie systému pred jeho uvedením a jeho následná periodická kontrola. $\mathrm{K}$ tomu je samozrejme

\footnotetext{
${ }^{252}$ Ibid., článok 6.2 .

${ }^{253}$ bid., článok 6.3.

${ }^{254}$ Ibid., Appendix C.
} 
potrebné zaistenie transparentnosti, resp. zaručenie vol’ného prístupu k systému a všetkým jeho komponentom. Tiež by malo byt zaručené, že už prvotný dizajn systému je v súlade s platným právom a nijak z neho nevybočuje. $^{255}$

\subsection{DE LEGE FERENDA}

Zrejme žiadny zo záverov porovnania jednotlivých aspektov práva na spravodlivý proces s procesom automatizácie nevedie k záveru, že tieto dve oblasti sú absolútne nezosúladitel’né. Zároveň však ani nenechávajú vel'a priestoru pre prehnaný optimizmus a je jasné, že k implementácii plne automatizovaných rozhodovacích systémov bude okrem technického pokroku a širšej spoločenskej akceptácie takéhoto zásahu potrebné upravit podmienky súdneho procesu, resp. ustanovit určité záruky ich fungovania.

Tieto podmienky by jednako mali vyplynút z jednotlivých záverov, ktoré boli článkom rozobraté a zároveň by sa nemalo jednat o také odporúčania, ktoré by podstatným spôsobom menilo či inak zasahovalo do existujúcich procesných pravidiel. $\mathrm{V}$ ideálnom prípade by malo byt možné všetky tieto podmienky implementovat’ „popri“ existujúcich procesných normách. ${ }^{256}$ Zároveň budeme uvažovat nad „minimálnou“ úpravou, ktorej účelom je zaručit zachovanie práva na spravodlivý proces a nebudeme sa zaoberat’ úpravou, ktorá by vd’aka charakteristikám automatizovaného procesu mohla viest̉ k zlepšeniu toho či onoho aspektu spravodlivosti.

Jeden $\mathrm{z}$ najväčších problémov, na ktorý sme $\mathrm{v}$ tejto práci narazili, je problém nezaujatých a vlastne aj nestranných súdov. Okrem extenzívneho výskumu na strane počítačovej vedy, je možné postúpit aj určité právne kroky, ktoré by mali viest’ k zníženiu možného negatívneho dopadu na

\footnotetext{
${ }^{255}$ Samozrejme je tu otázka medzier v práve a ich možného preklenutia „etickým uvažovaním“, ako navrhuje Panel. K otázke problému kompletnosti právnych systémov bude v krátkosti pojednané ešte záverom práce.

${ }^{256}$ Dobrým príkladom takéhoto postupu, fungujúceho popri existujúcich normách je napríklad článok 6.1 Nariadenia o automatizovanom rozhodovaní, ktoré posudzuje dopad algoritmického rozhodovania na jeho subjekty ešte pred jeho implementáciou. Pre dodržiavanie takéhoto nároku teda nie je nijaký spôsobom potrebné menit̉ procesné normy.
} 
účastníkov sporu v dôsledku takto chybne operujúcich expertných systémov.

Prístup, ktorý v tomto ohl'ade volí Kanada, sa javí byt celkom vhodný a rozhodne je na mieste sa ním do určitej miery inšpirovat. $\mathrm{V}$ prvom rade totižto chceme predchádzat tomu, aby vôbec bol niekedy takto chybne nastavený systém využitý. Ideálnym sa $\mathrm{k}$ takémuto účelu javí byt̉ predbežné testovanie a posudzovanie dopadu systému na jednotlivých účastníkov spo$\mathrm{ru}^{257}$ Takýto prístup považuje za vhodný aj Panel, a to, že mu pripisuje zvláštne postavenie, sa dá vyčítat’ zo skutočnosti, že takýto postup zahŕňa $\mathrm{v}$ dvoch $\mathrm{z}$ troch bodov etickej a dôveryhodnej AI. Konkrétne pod podmienkou etickosti vidí minimalizáciu (negatívneho) dopadu na subjekty, ktorú je najvhodnejšie docielit preemptívnym testovaním systému. Túto zásadu d’alej opakuje v požiadavke robustnosti systému, ktorá má zahŕňat jednak opätovnú minimalizáciu, ale aj prevenciu takýchto negatívnych javov. ${ }^{258}$

Odporúčania Panelu predstavujú generálne odporúčanie pre všetky budúce systémy využívajúce akúkol’vek formu algoritmizácie, resp. umelej inteligencie. Aj z tohto dôvodu je toto odporúčanie skôr všeobecné a necieli na problém zaujatosti v rozhodovacích systémoch, resp. celkovo ani na automatizované rozhodovacie systémy .

Vhodné by preto mohlo byt túto požiadavku doplnit’ o také, ktoré sú bližšie samotným rozhodovacím systémom. V tomto ohlade je takejto úprave bližšia kanadská úprava, ktorá v závislosti na závažnosti automatizovaného procesu vyžaduje určitú mieru externej, nezávislej kontroly tohto systému. Tá sa stupňuje od kontroly inou súčastou verejnej moci, externou kontrolou súkromným sektorom, až po kontrolu odbornou verejnostou v podobe peer-reviewed publikácie. ${ }^{259} \mathrm{Na}$ mieste je teda zavedenie požiadavky kontroly zameranej práve na tento problém, ktorá bude vykonaná tretou stranou.

Všeobecné požiadavky na kontrolu, ktoré musíme mat’ na používanie expertných systémov, by však nemali končit jeho zavedením. Jednako vždy

\footnotetext{
257 Secretariat, T. B. of C. Directive on Automated Decision-Making, článok 6.1.

${ }^{258}$ High-level expert group on artificial intelligence. Ethics guidelines for trustworthy AI, s. 6.

${ }^{259}$ Secretariat, T. B. of C. Directive on Automated Decision-Making, Appendix C.
} 
existuje možnost’ výskytu extrémnych situácií, ktoré pri testovaní neboli predpokladané a práve tak by malo priebežné testovanie prispiet k odhal'ovaniu využitia nesprávnych dát. V neposlednom rade, v závislosti od spôsobu, akým by bol systém navrhnutý a aké algoritmy by užíval, by mal kontrolovat možný vývoj algoritmu. ${ }^{260}$

Na otázku priebežnej kontroly fungovania systému nadväzuje aj d’alšia podmienka, bez splnenia ktorej je možné automatizáciu systémov možné označit v podstate za neprípustné. Touto podmienkou je celková transparentnost’ systému. Kanadské Nariadenie k tejto otázke pristupuje z časti obmedzenejšie, kedy túto transparentnost’ vyžaduje jednako voči štátu, a to požiadavkou na zachovanie plného prístupu ku každej zložke takéhoto systému vládnou organizáciou, ktorá automatizované rozhodovanie využíva, a voči verejnosti formou zverejnenia zdrojového kódu. Toto ustanovenie transparentnosti voči širokej verejnosti je však obmedzené napríklad proprietárnou licenciou alebo utajovanou povahou daného systému a jeho aplikácie. $^{261}$

Pre potreby automatizácie súdneho rozhodovania je však potrebné odmietnut akékol'vek výnimky z tohto princípu, ktoré by nás vracali do čias kabinetnej justície a práve naopak, snažit’ sa o informačnú transparentnost', teda čo najširší prístup k čo najširšiemu množstvu dát.

Tento prístup by mal byt’ ideálne doplnený o vytváranie určitých aproximatívnych modelov fungovania rozhodovacieho algoritmu a to jednak za účelom odstránenia možného vzniku „black box“ algoritmu, ktorý zo svojej podstaty ide proti významu informačnej transparentnosti a jednak preto, aby boli takto zverejnené informácie prístupné čo najširšej verejnosti.

Nadväzujúc na to, je tu posledný problém, ktorým sme sa zaoberali a to nárok na odôvodnené rozhodnutia. Tento nárok je však garantovaný aj

\footnotetext{
${ }^{260}$ Ako anekdotálny príklad poslúži príklad chatbota „Tay“ vyvinutého spoločnostou Microsoft, ktorý sa mal učit „ludskej“ komunikácii prostredníctvom interakcie s užívatel’mi platformy Twitter. Skutočnost', že Tay museli po dni vypnút pre jej rasistické poznámky svedčí jednak o potrebe následnej kontroly vývoja algoritmu, tak aj o potrebe kontroly dát, $s$ ktorými algoritmus pracuje. Vid: Vincent, J. Twitter taught Microsoft's friendly AI chatbot to be a racist asshole in less than a day [online]. The Verge. 24. 3. 2016 [cit 6. 3. 2021]. https://www.theverge.com/2016/3/24/11297050/tay-microsoft-chatbot-racist

${ }^{261}$ Secretariat, T. B. of C. Directive on Automated Decision-Making, body 6.2 a 6.3 .
} 
súčasnou právnou úpravou, ako sme rozoberali vyššie. Expertné systémy by mali k nemu takisto pristupovat tak, aby tieto podmienky naplnili. Je možné predpokladat, že aj súčasná úprava do určitej miery obsahuje požiadavku, aby odôvodnenia boli zrozumitel'né, no s ohl'adom na technickú komplexnost' odôvodnení produkovaných expertnými systémami, by bolo vhodné normatívne stanovit’, alebo aspoň zdôraznit formu, ako by mali takéto odôvodnenia vyzerat', aby túto podmienku naplnili.

Táto čast’ si nerobí ambíciu príst’ s návrhom zákona, či nejakého druhu normy, ktorá by mala byṫ konkrétnou úpravou tohto problému. No body navrhnuté v tejto časti, by mali slúžit ako vhodný odrazový mostík pre možnú budúcu úpravu, ktorá by mala zaručit', že právo na spravodlivý proces bude účastníkom garantované aj v automatizovaných procesoch. Zároveň je však potrebné mat̊ na pamäti, že sa jedná o technicky značne komplexný problém a táto možná normatívna úprava je len zlomkom otázok, ktoré treba mat’ na pamäti pri zavádzaní automatizácie v súdnictve.

\section{ZÁVER}

Ciel’om článku bolo posúdit možnosti implementácie automatizovaných rozhodovacích systémov s ohl'adom na nároky, ktoré na súdny proces kladie právo na spravodlivý proces. Na takúto možnú budúcu implementáciu sme kládli dve podmienky, v intenciách ktorých bolo toto právo posudzované. Malo by íst’ o úplnú automatizáciu, pričom sa úplnou automatizáciou nemusí nutne chápat automatizácia úplne kompletného systému súdnictva, ale taká automatizácia, ktorá v danom prípade, kedy je k nej pristúpené, už nevyžaduje žiaden d’alší zásah od človeka. ${ }^{262}$ Ďalším pravidlom, ktoré bolo primárne reflektované $\mathrm{v}$ predchádzajúcej časti, bola podmienka, že takáto implementácia bude schopná sledovat existujúce procesné normy a nebude do nich treba zasahovat preto, aby sme takýto postup umožnili. ${ }^{263}$

\footnotetext{
${ }^{262}$ Teda tak, že automatizované môžu byt kludne iba niektoré druhy súdnych konaní a iné zase nie, no ak je niektorý druh konania automatizovaný nie sú prípustné zásahy od ludú, ako napríklad systém, ktorý by síce vyprodukoval rozhodnutie, no rozsudok, či odôvodnenie by musel spisovat človek.
} 
V úvode práce bol čitatel' oboznámený s rôznymi výkladmi práva na spravodlivý proces, ktoré boli primárne založené na jeho vnímaní v Dohovore a v Listine. Toto právo je samo o sebe velmi komplexné a nestanovuje len jedno právo. Tento termín má slúžit skôr ako súborný opis celej zložky práv, ktorých výsledkom spoločného uplatnenia by mal byt spravodlivý proces. Okrem oboznámenia čitatel’a $s$ touto problematikou, mala táto čast̉ za úlohu založit doktrinálne vnímanie jednotlivých aspektov, z ktorých sa toto právo skladá. Na základe rozobratej literatúry bolo určené, že za doktrinálne uznané aspekty práva na spravodlivý proces je možné považovat a) právo na prístup $\mathrm{k}$ súdu, b) právo na nestranný a nezaujatý súd, c) právo na včasné konanie, d) právo na spravodlivé konanie. $\mathrm{V}$ rámci práva na spravodlivé konanie bolo posúdených niekol'ko zostatkových kategórií, z ktorých (z pohl’adu automatizácie) je najvýraznejším problémom nárok na odôvodnenie rozhodnutia. Ďalším bodom, ktorý bol v tejto práci rozobratý a nevyplynul zo samotného doktrinálneho výkladu tohto práva, ale až z následného rozboru automatizácie, je problematika transparentnosti.

Pri zvážení práva na prístup $\mathrm{k}$ súdu a automatizácie sme sa zaoberali najmä problémom možného digitálneho vylúčenia. Nakoniec sa však ukázalo, že jednako je tento problém o dosť menší než by sa mohlo zdat a hlavne miera neustále sa zvyšujúcej digitálnej gramotnosti ho robí stále menej významným. S ohl’adom na tento problém boli rozobraté niektoré riešenia navrhované inými autormi, napríklad existencia rôznych asistenčných služieb a kontaktných bodov. ${ }^{264}$ Vo všeobecnosti sme však túto kapitolu uzavreli s tým, že automatizácia zrejme nebude predstavovat žiad-

\footnotetext{
${ }^{263}$ Tu nutno podotknút dve situácie, ktoré by sa mohli javit ako výnimky z tejto podmienky, a zároveň nimi však nie sú. Prvá je úprava nárokov na automatizované systémy, ktoré sú vlastné len týmto systémom a nijak nezasahujú do procesných pravidiel, ktoré už existujú. To je v zásade úprava, ktorá bola navrhnutá v sekcii 5.2. Druhou takouto situáciou je možná budúca úprava, ktorá za účelom zväčšenia spravodlivosti súdneho procesu využíva niektoré z vlastností expertných systémov, a za týmto účelom pozmeňuje procesné pravidlá. Niektoré takéto situácie boli pri jednotlivých aspektoch $\mathrm{v}$ tejto práci naznačené, no obecne nie je ambíciou tejto práce rozoberat možnosti zlepšovania, dôraz bol kladený na zachovanie súčasných procesných noriem. No obecne je možné takéto zmeny pripustit aj pri zachovaní práva na spravodlivý proces, no určite si budú vyžadovat d’alšie samostatné pojednanie.
} 
ny problém pre právo na prístup k súdu. Na mieste sa javí skôr predpokladat’ zlepšenie v tomto ohl'ade. Problém digitálneho vylúčenia je skutočne zanedbatel’ný, takisto aj ten je možné odstránit’ vhodným nastavením spôsobu, akým bude automatizácia do systému implementovaná.

Okrem tohto nového problému, ktorý by mohol byt̉ predstavený až s príchodom automatizácie, kapitola rozoberala aj niektoré už existujúce prekážky prístupu k súdu, akými sú súdne poplatky, rôzne procesné obmedzenia napríklad v podobe stanovených prekluzívnych lehôt a kultúrne či sociálne prekážky prístupu k súdu vo všeobecnosti. V tomto bode sme nedospeli k záveru, že by automatizácia mala mat̉ nejaký zvláštny dopad na niektorú z týchto oblastí. Otázkou k d’alšiemu výskumu, a to nie len právnemu, by mohol byt’ vztah práve kultúrnych a sociálnych prekážok a automatizácie, no v rozsahu tejto práce bol problém sociálnych prekážok viac menej pokrytý otázkou digitálneho vylúčenia.

Okrem aspektu práva na prístup $\mathrm{k}$ súdu sa práca venovala aspektu včasnosti súdneho konania. Tento problém je v súčasnosti najväčšou prekážkou pre právo na spravodlivý proces, resp. sú to práve súdne prietahy, ktoré tvoria najväčšiu zložku stažností pred ESL’P. Ako poukazujú mnohí autori, ktorých prácam sme sa venovali, tento problém je tak rozšírený, že je možné ho označit’ za systémový a je teda jasné, že sa jedná o skutočne obšírny a hlboko zakorenený problém. Ciel’om tejto práce však naštastie nie je ho vyriešit, namiesto toho sme sa zamerali na jeho rozdelenie na dve kategórie, v rámci ktorých sme potom d’alej skúmali vplyv automatizácie.

$\mathrm{V}$ prvom rade sa jednalo o prietahy vznikajúce $\mathrm{v}$ dôsledku (ne)činnosti účastníkov procesu. Toto je skôr otázka úpravy vôle, ktorá je v rámci procesu jednotlivým účastníkom povolená a teda ako taká je skôr otázkou nastavenia procesných pravidiel ako takých. V tomto bode sme nepredpokladali žiadne ovplyvnenie procesom automatizácie. Záverom bolo čitatel’ovi poskytnuté vel’mi strohé predstavenie možností, ako by automatizácia mohla spolu so zmenou niektorých procesných pravidiel prispiet’ k zlepšeniu aj tejto situácie, avšak s ohl'adom na tézu zachovávania existujúcich pravidiel,

${ }^{264}$ Susskind, R. Online courts and the future of justice. Oxford: Oxford University Press, 2019, s. $215-221$. 
ktorej sa táto práca drží, boli tieto otázky skôr naznačené a zasluhujú si samostatné pojednanie.

V druhej kategórii sa táto práca zamerala na prietahy vzniknuté na strane sudcov. Zo štúdií, ktoré boli $\mathrm{v}$ tejto časti práce prezentované vyplýva, že najväčšiu čast práce sudcu v procese zaberá jednak rozhodovanie ako meritórne, tak aj prípadné priebežné rozhodnutia a následné vyhotovovanie rozsudku. Ked’že je to primárne sudcovské rozhodovanie, ktoré sa snažíme automatizáciou nahrádzat', samotné posúdenie dopadu bude závisiet od technologického postupu, ktorý bude zvolený. Ako sme však poukazovali na viacerých miestach $\mathrm{v}$ tejto práci, technologické riešenie $\mathrm{v}$ uvádzanom prípade so sebou prináša väčšiu výpočtovú kapacitu, ktorá je schopná v kratšom čase spracovat’ omnoho väčšie množstvo dát a vstupných údajov než ludská mysel'. Je nepochybne na mieste sa domnievat, že nahradenie sudcovského rozhodovania, ktoré na strane sudcu zaberá najviac času, povedie skôr k pozitívnym výsledkom. Preto by včasnost̉ nemala predstavovat absolútnu prekážku implementácie automatizovaných rozhodovacích systémov.

Ďalším, relatívne obšírnym aspektom, ktorý sme $\mathrm{v}$ práci rozoberali, bolo právo na nezaujatý a nezávislý súd. Pri rozbore týchto dvoch nárokov sme si pomohli hlavne testami, ktoré na ich posudzovanie zavádza ESL'P.

Pri pohlade na nezávislost bola analyzovaná hlavne možnost inštitucionálneho ovplyvnenia a ovplyvnenia inou zložkou moci. S ohladom na technické vlastnosti automatizovaných systémov takéto ovplyvnenie prakticky nepredstavuje žiadne riziko. Ako určitá „nová“ forma inštitucionálneho ovplyvnenia by však v prostredí automatizovaných rozhodovacích systémov mohol figurovat zámerne chybný algoritmický dizajn. Zníženie dopadu, resp. vôbec možnosti vzniku tejto chyby, je vhodné riešił spolu s problémami druhej časti tohto práva, s právom na nezaujatý súd.

Nezaujatost̉ súdneho rozhodovania bola $\mathrm{v}$ tejto práci posúdená primárne na základe dvoch kategórií, ktoré pri tomto posudzovaní používa ako ESL'P, tak aj Ústavný súd, a to funkčnej (objektívnej) a osobnej (subjektívnej). Tak ako v mnohých bodoch výkladu práva na spravodlivý proces, aj aspekt nezaujatosti je vnímaný značne antropocentricky, a tieto kategórie sa nutne 
nevztahujú na strojové rozhodovanie. To však neznamená, že môžeme s čistým svedomím túto kategóriu opustit, nakol'ko nám do hry vstupuje nový druh zaujatosti. Čitatel' bol preto oboznámený s technologickou problematikou zaujatosti algoritmov, ako aj rôznymi technologickými riešeniami, resp. prístupmi, ktoré $\mathrm{k}$ tomuto problému v súčasnosti volí počítačová veda. Jedná sa však stále o živý problém a pre vynesenie jasného záveru, že ani tento aspekt nepredstavuje pre automatizáciu problém, bude ešte stále potrebný určitý vývoj aj na poli technológií.

Avšak navzdory tomu bolo záverom kapitoly predstavených niekolko možných (normatívnych) prístupov $\mathrm{k}$ tomuto problému, ktoré by bolo vhodné reflektovat v prístupe k zavádzaniu takýchto systémov. Na jednej strane je potrebné klást dôraz na rozsiahle testovanie systémov, ktoré by mali ešte pred ich zavedením odhalit takéto negatívne javy a následne je nutné ich kontrolovat aj po spustení, s ohl’adom na rozhodnutia, ktoré vydávajú. Druhou podmienkou, ktorá by v podstate mala smerovat $\mathrm{z}$ vel'kej časti $\mathrm{k}$ predchádzaniu určitej formy inštitucionálneho ovplyvnenia, je nutnost transparentnosti systémov.

Transparentnost je jedna z rozhodujúcich podmienok daných systémov, ktorá má zaručit možnost verejnej kontroly a predchádzaniu, resp. možnosti inštitucionálneho ovplyvnenia a zároveň je podstatná pre zvyšovanie legitimity takýchto systémov (ktorá do určitej miery dopadá aj na sociálno-kultúrne prekážky prístupu k súdom). Rovnako umožňuje verejnosti oboznámit sa so spôsobom výkonu spravodlivosti, čo nás privádza k nároku na verejnosṫ súdneho konania.

Hned’ na prvý pohl’ad sa môže zdat', že daný nárok nebude možné zaistił v automatizovaných súdnych konaniach a tento záver bol viac menej potvrdený aj začiatkom tejto časti práce. Pred unáhleným záverom, že sa nám podarilo nájst absolútnu prekážku automatizácie, je však vhodné si uvedomit, že každý $\mathrm{z}$ aspektov práva na spravodlivý proces neexistuje sám pre seba, ale má na to určitý širší dôvod, ktorý za jeho vznikom stojí. V prípade verejnosti konania doktrinálna literatúra identifikuje dva účely. Jedným je ochrana účastníka procesu pred zneužitím štátnej moci (prostredníctvom záruky verejnej kontroly) a druhým je možnost̉ verejnosti 
oboznámit sa s takýmto výkonom štátnej moci (čo má okrem iného prispievat napríklad k zvýšeniu právneho povedomia). K takémuto „rozkladu“ verejnosti konania vyzýva aj literatúra, v ktorej môžeme nájsț delenie na reálnu transparentnost', ktorá je predstavovaná princípom verejnosti a ktorú budeme musiet zrejme obetovat automatizácii, resp. digitalizácii vo všeobecnosti, d’alšia je informačná transparentnost'.

Navrhovaná informačná transparentnost’ sa vracia k predchádzajúcemu odstavcu, v ktorom sme pri nezaujatosti zdôrazňovali potrebu transparentných, otvorených algoritmov. Informačná transparentnost̉ totiž stojí na vhodnom zverejňovaní čo najväčšieho množstva informácií o procese, či už sú to informácie o skutkovej podstate, odôvodnenom rozhodnutí alebo o spôsobe rozhodovania ako takom, teda uverejnenie rozhodovacieho algoritmu.

Takéto zverejnenie má okrem suplovania funkcie verejnosti a umožnenia kontroly slúžit aj ako informačný zdroj pre širokú verejnost', aby sa jednak mohla oboznámit s výkonom štátnej moci (ktorá je napokon vykonávaná v ich mene) a aby mohli patrične uspôsobit svoju procesnú stratégiu s čím súvisí aj d’alší bod, ktorý bol v tejto časti rozobratý. Ide o vytváranie aproximatívnych modelov a problematiku explainable AI všeobecne, ktoré majú pomôct' lud’om pochopit fungovanie týchto automatizovaných systémov a zároveň predchádzat problematike black box algoritmov, ktoré sú pri výkone spravodlivosti absolútne neprípustné. Rovnako ako black box-y, sú s ohl’adom na potrebu transparentnosti absolútne neprípustné rôzne proprietárne, či inak utajované algoritmy, napríklad z dôvodu obchodného tajomstva alebo iného licenčného problému. Ak sa podarí zabezpečit dostatočnú mieru transparentnosti, je možné pripustit opustenie formy reálnej verejnosti, ktorej zaistenie v prostredí automatizovaných rozhodovacích systémov nie je možné zaručit, za predpokladu, že bude dostatočne vyvážená zvýšenou informačnou transparentnostou procesu.

V tomto bode ostáva vyrovnat sa už len s posledným nárokom, ktorým je súhrnná kategória práva na spravodlivé konanie. Tak ako komentárová literatúra, aj táto práca venuje väčšine zložkových aspektov len minimálny priestor a to z jednoduchého dôvodu. Pri mnohých z nich, ako napríklad 
procesná rovnost', stanovenie dôkazných pravidiel či kontradiktórnost konania, jednoducho nie je dôvod sa domnievat, že by boli akýmkolvek spôsobom ovplyvnené procesom automatizácie.

Zložkový aspekt práva na spravodlivé konanie, ktorý si však zaslúži bližší pohlad a ktorému sa táto práca venovala záverom 4. kapitoly, je právo na odôvodnené rozhodnutie. S ohl'adom na automatizované rozhodovanie nás zaujímali najmä dve veci, na ktoré je potrebné si dat pozor pri ich zavádzaní. Ako prvé je potrebné zaistit', aby samotný systém „vedel čo robí“, čo znamená, že je prijatel’né používanie iba takého systému, ktorý dokáže zároveň s korektným rozhodnutím vyprodukovat dostatočne podrobný záznam o tomto procese (a zároveň musíme mat dostatočné znalosti o tomto procese ako takom, no tento problém bol pokrytý už v časti o transparentnosti). Ďalší, zrejme pálčivejší problém je, že tento záznam musí mał formát, ktorý je prístupný aj priemerne inteligentnému človeku. V ideálnom prípade by určitým spôsobom kopíroval odôvodnenia, ktoré máme dnes. Toto sú podmienky, ktoré na tento aspekt kladie právo a to, či sme schopní príst s expertným systémom, ktorý ich vie naplnit', je skôr technickou otázkou. Preto bol čitatel' v nasledujúcej časti tejto kapitoly oboznámený so súčasnými technickými riešeniami, akými je textový generatívny model GPT3, ktoré majú potenciál takéto dostatočne zrozumitelné odôvodnenia vyprodukovat', alebo minimálne naznačujú vhodnú cestu pre budúci vývoj v tejto oblasti.

Daný rozbor predstavoval hlavnú čast práce a jeho záverom bolo možné zhodnotit, že v doktrinálnom ponímaní práva na spravodlivý proces neexistuje taký aspekt, ktorý by pre automatizáciu rozhodovacej činnosti predstavoval absolútnu prekážku. Počas tejto analýzy sme však narazili na množstvo aspektov, alebo čiastkových otázok, na ktoré si treba dávat', prinajmenšom, pozor. Piata kapitola mala byt pokusom o určitý normatívny návrh, ktorý by mal zdôraznit práve tieto body.

V úvode bol čitatel' oboznámený s existujúcim pozitívnym právom a inými kvázi-normatívnymi dokumentami, ktoré sa tejto oblasti venujú. V priestore krajín Rady Európy v súčasnosti takáto úprava na zákonnej úrovni neexistuje, preto boli čitatelovi predstavené dokumenty, ktoré majú 
k tomu najbližšie, konkrétne výstupy z činnosti High Level Expert Group on AI, zriadenej Európskou komisiou. Tá vo svojom odporúčaní pre etickú a dôveryhodnú umelú inteligenciu predstavuje niekol'ko princípov, ktoré by spomínané systémy mali sledovat a ktoré boli čiastočne reflektované aj v nasledujúcej časti návrhu úpravy.

Ďalej bol čitatel' oboznámený s kanadskou úpravou v podobe Nariadenia o automatizovanom rozhodovaní, ktoré upravuje systémy svojou povahou vel’mi blízke systémom, ktoré predpokladá táto práca a to navyše na zákonnej úrovni.

Oba tieto dokumenty slúžili ako inšpirácia pre podkapitolu 5.2 tejto práce, ktorá s ohl’adom na čiastkové závery jednotlivých kapitol odporučila body, ktoré by mohli byṫ zapracované do budúcej normatívnej úpravy, existujúcej popri procesných normách. Táto má predchádzat možným negatívny dopadom automatizovaného posúdenia.

$S$ takto vhodne nastavenou právnou úpravou je možné článok uzavriet? s tým, že právo na spravodlivý proces nepredstavuje absolútny problém pre automatizáciu súdneho rozhodovania. Zároveň je však nutné podotknút, že tento záver sa vztahuje výhradne na právo na spravodlivý proces a pred zavedením automatizácie v tejto oblasti existuje ešte mnoho d’alších otázok, ktorým je potrebné sa venovat.

\section{1 ĎALŠIE OTÁZKY}

Otázky spojené s právom na spravodlivý proces ani zd’aleka nie sú jediné, ktorým sa treba v súvislosti so zavádzaním expertných systémov venovat. Medzi otázky, ktoré už boli naznačené v texte, patrí napríklad problém toho, že niektoré aspekty si vyžadujú, aby boli „videné“. Nestačí, že súd je nezaujatý, ale musí tak aj pôsobit, ${ }^{265}$ čo sa všeobecne vztahuje na spravodlivosṫ ako celok. Pre jej spoločenskú úlohu nestačí, aby bola len vykonávaná férovo, ale aby ju ako takú l’udia aj videli. ${ }^{266}$ Ďalej sú tu tiež rôzne

\footnotetext{
${ }^{265}$ Hauschildt proti Holandsku, odstavec 46.

${ }^{266}$ Datar, A. The origins of "Justice must be seen to be done" [online]. Bar and Bench - Indian Legal news [cit 7. 3. 2021]. https://www.barandbench.com/columns/the-origins-of-justicemust-be-seen-to-be-done
} 
sociálne a kultúrne aspekty, ako napríklad význam sociálnych konštruktov pre spravodlivost a ich preklopenie do strojového rozhodovania, ${ }^{267}$ či vôbec miesto jednotlivých spoločenských hodnôt v systéme spravodlivosti, ${ }^{268}$ či volnejšie posudzovanie niektorých zložiek prípadov, oproti striktnému pozitivizmu, ktoré sú, podstatné pre restoratívnu spravodlivosté. Velmi podstatnou otázkou pre úspech automatizovaných rozhodovacích systémov v súdnictve je aj otázka dôvery širokej verejnosti, ako „konzumentom statku spravodlivosti“ ${ }^{269}$

Takéto otázky nás pomaly dostávajú do určitej meta-právnej roviny, kde sa nachádzajú mnohé d’alšie otázky, súvisiace s automatizáciou. Otázku či je možné právo, resp. súdne rozhodovanie algoritmizovat, môžeme síce uzavriet s poukázaním na to, že algoritmické musí byt aj ludské rozhodovanie a akýkolvek iný záver predsa musí znamenat svojvôlu, prípadne sa odkázat na Hartovu maximu, že spravodlivé rozhodovanie znamená rozhodovat „rovnaké prípady rovnako, a odlišné odlišne“. ${ }^{270}$ Na mieste je však úvaha o kompletnosti a vnútornej konzistentnosti (logického) systému práva a či je vôbec jej možné dosiahnut. ${ }^{271}$ Jednou z nepochybných výhod expertných systémov je ich schopnost posudzovat až nesúmeratel'né množstvo dát oproti ludský sudcom, čo v podstate pripomína Dworkinov koncept sudcu Herkula, s perfektnou znalostou. Perfektná znalost̉ si však pýta vysporiadat sa s otázkou, hranice medzi perfektnou znalostou a súkromím a toho aké všetky dáta o stranách sporu môže takýto systém zvažovat', a akým spôsobom. ${ }^{272}$

${ }^{267}$ Algorithms and human rights - Study on the human rights dimensions of automated data processing techniques and possible regulatory implications [online]. COE [cit 7. 3. 2021]. https://edoc.coe.int/en/internet/7589-algorithms-and-human-rights-study-on-the-humanrights-dimensions-of-automated-data-processing-techniques-and-possible-regulatory-implications.html

${ }^{268}$ Hayes, Van de Poel, Steen. Algorithms and values in justice and security.

${ }^{269}$ Kok, B. C., Soh, H. Trust in Robots: Challenges and Opportunities. Current Robotics Reports. 2020, č. 4.

${ }^{270}$ Hart, H. Pojem práva. Praha: Prostor, 2011, s. 159-168.

${ }^{271}$ Bavli, H. Applying the Laws of Logic to the Logic of Laws. In: Fordham Urban Law Journal, ročník 33, číslo 3 , s. $101-114$. 
Za pozornosṫ tiež stoja otázky vývoja práva, aký dopad bude mat̉ takéto „syntetické“ rozhodovanie na „otvorenú textúru“ a vývoj práva, ktorého interpretácia a ponímanie sa mení v čase a čiastočne stojí na nevhodných rozhodnutiach a iných odklonoch od zaužívaného narábania s ním. ${ }^{273} \mathrm{~S}$ týmito otázkami súvisí aj všeobecná vôla zákonodarcu podstupovat extenzívnu novelizáciu procesných pravidiel, ak by to znamenalo, že expertný systém, ktorého vývoj bol zrejme značne nákladný by d’alej nebol použitel’ný alebo by si žiadal dodatočné náklady.

Otázka nákladov nás následne privádza k d’alšiemu bodu, ktorý zdôrazňuje najmä Susskind, teda že pre akúkol’vek technologickú inováciu nestačí, že dokonale napodobňuje existujúci stav ale ak nie je schopná ho vylepšit, nemá význam. ${ }^{274}$ Danú otázku táto práca takpovediac obišla, nakol'ko našim kritériom bolo dosiahnutie minimálneho prípustného stavu, ktorý je v súčasnosti predstavovaný l’udskými sudcami. No je zrejmé, že na to, aby sa vývoj a zavádzanie takéhoto systému oplatilo, musí vo výsledku priniest’ viac než len súčasný stav v jednotkách a nulách. Otázka miery inovácie, v ktorej sa už oplatí nad takýmito zmenami uvažovat, je preto vhodným predmetom d’alšieho výskumu, spolu s mnohými d’alšími, ktoré $\mathrm{s}$ touto problematikou súvisia a $\mathrm{v}$ tejto práci pre ne nebol priestor.

\section{POUŽITÉ ZDROJE}

\subsection{MONOGRAFIE}

[1] Bahýlová, L. a kol. Ústava české republiky - komentár̆. Praha: Linde, 2010.

\footnotetext{
${ }^{272}$ To je stále aktuálnejšia otázka najmä s ohladom na zväčšujúce sa množstvo dát, ktoré je takým či onakým spôsobom zbieraných a môžu byt relevantné pre súdne konanie, ako napríklad v nedávnej veci vraždy Jána Kuciaka na Slovensku, kedy okrem geolokačných dát mobilných telefónov, boli súdu prokurátorom prezentované aj dáta o tepovej frekvencii obžalovanej, zachytené na jej chytrých hodinkách. Cuprík, R. Inteligentné hodinky merajú tep presne, vzahraničí odhalujú vrahov [online]. SME [cit. 20.3. 2021]. https://domov.sme.sk/c/22603692/mozu-zsuzsovej-hodinky-obstat-ako-dokaz-v-zahraniciodhalovali-vrahov.html

${ }^{273}$ Markou, C., Deakin, S. Ex Machina Lex: Exploring the Limits of Legal Computability. Rochester, NY: Social Science Research Network, 2019, s. 24-26 [cit 7. 3. 2021]. https:// papers.ssrn.com/abstract $=3407856$

${ }^{274}$ Susskind, R. Online courts and the future of justice. Oxford: Oxford University Press, 2019.
} 
[2] Banaji, M. R., Greenwald, A. G. Blindspot: Hidden Biases of Good People. Delacorte Press, 2013.

[3] Bartoň, M., Kratochvíl, J., Kopa, Martin. Základní práva. Praha: Nakladatelství Leges, s.r.o., 2016.

[4] Cormen, T., H. et al. Introduction to algortihms. Cambridge: MIT Press, 2009.

[5] David, R. Ústava České republiky - Listina základních práv a svobod. Olomou: Vydavatelství Olomouc, 2005.

[6] Harris, D., O'Boyle, M., Warbrick, C. Law of the European Convention on Human Rights. New York: Oxford University Press, 2009.

[7] Hart, H. Pojem práva. Praha: Prostor, 2011.

[8] Kmec, J. et al. Evropská úmluva o lidských právech: komentár̆. Praha: Nakladatelství C. H. Beck, 2012.

[9] Knuth, D., E. Uměmí programování. 1.díl. Základní algoritmy.. Brno: Computer Press, 2008.

[10] Leanza, P., Pridal, O. The Right to a Fair Trial: Article 6 of the European Convention on Human Rights. Netherlands: Kluwer Law International.

[11] Loutocký, P. Vymahatelnost práva pomocí online řešení sporů. Praha: Wolters Kluwer, 2020.

[12] Mak, V. et al (eds.). RESEARCH HANDBOOK IN Data Science and Law. Northampton: Edward Elgar Publishing.

[13] Moeckli, D., Shah, S., Sivakumaran, S. International Human Rights Law. New York: Oxford University Press, 2010.

[14] Molek, P. Právo na spravedlivý proces. Praha: Wolters Kluwer, 2012.

[15] Nikolopoulos, C. Expert Systems: Introduction to First and Second Generation and Hybrid Knowledge Based Systems. New York: CRC Press - Taylor \& Francis Group, 1997.

[16] Puppe, F. Systematic Introduction to Expert Systems: Knowledge Representations and Problem-Solving Methods. Berlín: Springer, 1993.

[17] Susskind, R. Online courts and the future of justice. Oxford: Oxford University Press, 2019.

[18] Svoboda, K., et al. Občanský soudní řád. 2. vydání. Praha: Nakladatelství C. H. Beck, 2017.

[19] Wagnerová, E. et al. Listina základních práv a svobod. Komentár̆. Praha: Wolters Kluwer, 2012.

[20] McCorduck, P. Machines Who Think: A Personal Inquiry into the History and Prospects of Artificial Intelligence. Boca Raton: Routledge \& CRC Press, 2004. 


\section{2 ČLÁNKY}

[21] Barton, N. T.-L., Paul Resnick, and Genie. Algorithmic bias detection and mitigation: Best practices and policies to reduce consumer harms [online]. Brookings. 22. 5. 2019 [cit 6. 2. 2021]. https://www.brookings.edu/research/algorithmic-bias-detection-and-mitigation-best-practices-and-policies-to-reduce-consumer-harms/

[22] Bielen, S., Marneffe, W. Are Courts to Blame for Delays in Belgian Civil Procedures?: A Decomposition of Case Duration. Justice System Journal. 2017, č. 4, s. 399-420.

[23] Brown, T. B. et al. Language Models are Few-Shot Learners. arXiv:2005.14165 [cs]. 2020 [cit 28. 2. 2021]. http://arxiv.org/abs/2005.14165

[24] Citron, D. K. Technological Due Process. Washington University Law Review. 2008, č. 6, s. $1249-1313$.

[25] Clune, J. AI-GAs: AI-generating algorithms, an alternate paradigm for producing general artificial intelligence. arXiv:1905.10985 [cs]. 2020 [cit 18. 3. 2021]. http://arxiv.org/abs/ 1905.10985

[26] Cuprík, R. Inteligentné hodinky merajú tep presne, v zahraničí odhalujú vrahov [online]. SME [cit. 20. 3. 2021]. https://domov.sme.sk/c/22603692/mozu-zsuzsovej-hodinky-obstatako-dokaz-v-zahranici-odhalovali-vrahov.html

[27] Datar, A. The origins of "Justice must be seen to be done" [online]. Bar and Bench - Indian Legal news [cit 7. 3. 2021]. https://www.barandbench.com/columns/the-origins-ofjustice-must-be-seen-to-be-done

[28] Desmarais, S. L., Lowder, E. M. Pretrial risk assessment tools: A primer for Judges, Prosecutors and Defense Attorneys [online]. MacArthur Foundation: Safety and Justice Challenge. [cit. 19.11.2020]. s. 12.

[29] Edel, F., Council of Europe. La durée des procédures civiles et pénales dans la jurisprudence de la Convention européenne des droits de l'homme. Strasbourg, France: Editions du Conseil de l'Europe, 2007.

[30] Goldenfein, J. Algorithmic Transparency and Decision-Making Accountability: Thoughts for Buying Machine Learning Algorithms. Rochester, NY: Social Science Research Network, 2019 [cit 27. 2. 2021]. https://papers.ssrn.com/abstract $=3445873$

[31] GPT-3. A robot wrote this entire article. Are you scared yet, human? | GPT-3 [online]. the Guardian. 8. 9. 2020 [cit 28. 2. 2021]. http://www.theguardian.com/commentisfree/ 2020/sep/08/robot-wrote-this-article-gpt-3

[32] Hayes, P., Van de Poel, I., Steen, M. Algorithms and values in justice and security. AI \& SOCIETY. 2020, č. 3, s. 533-555.

[33] Hutcheson, J. Judgment Intuitive The Function of the Hunch in Judicial Decision. Cornell Law Review. 1929, č. 3, s. 274-288. 
[34] Ibrahim, M. Justice for all: how technology is promoting public access [online]. Raconteur. 30. 11. 2018 [cit 23. 12. 2020]. https://www.raconteur.net/legal/technology-public-access-justice/

[35] Kitchin, R. Thinking critically about and researching algorithms. Information, Communication \& Society. 2017, č. 1, s. 14-29.

[36] Kılınç, B. A Trial to Understand the Concept of Fair Trial. Selçuk Üniversitesi Sosyal Bilimler Enstitüsü Dergisi. 2016, č. 35, s. 315-324-324.

[37] Kok, B. C., Soh, H. Trust in Robots: Challenges and Opportunities. Current Robotics Reports. 2020, č. 4, s. 297-309.

[38] Kusner, M. J. et al. Counterfactual Fairness. V: Guyon, I. et al. (ed.). Advances in Neural Information Processing Systems 30. Curran Associates, Inc., 2017, s. 4066-4076. http://papers.nips.cc/paper/6995-counterfactual-fairness.pdf

[39] Lewis, P. J. D., Ted G. Exponential Laws of Computing Growth [online]. [cit 8. 3. 2021]. https://cacm.acm.org/magazines/2017/1/211094-exponential-laws-of-computing-growth/ fulltext

[40] Maayan, E., Ronen, B., Coman, A. Assessing the Performance of a Court System: A Comprehensive Performance Measures Approach. International Journal of Public Administration. 2012, č. 11, s. 729-738.

[41] Markou, C., Deakin, S. Ex Machina Lex: Exploring the Limits of Legal Computability. Rochester, NY: Social Science Research Network, 2019 [cit 7. 3. 2021]. https://papers.ssrn.com/abstract $=3407856$

[42] McCarty, L. T. Reflections on TAXMAN: An Experiment in Artificial Intelligence and Legal Reasoning. Harvard Law Review. 1977, s. 837-893.

[43] Molnar, P., Gill, L. Bots at the Gate: A Human Rights Analysis of Automated Decision-Making in Canada's Immigration and Refugee System. 2018 [cit 3. 3. 2021]. https://tspace.library.utoronto.ca/handle/1807/94802

[44] Paseková, E. Délka civilního řízení loni opět klesla, trestní se prodloužilo [online]. Česká justice. 21. 8. 2019 [cit 27. 11. 2020]. https://www.ceska-justice.cz/2019/08/delka-civilnihorizeni-loni-opet-klesla-trestni-se-prodlouzilo/

[45] Paseková, E. Přetížení správního soudnictví se prohlubuje, NSS má přes dva a půl tisíce nevyřízených věcí [online]. Česká justice. 21. 8. 2019 [cit 2. 12. 2020]. https://www.ceskajustice.cz/2019/08/pretizeni-spravniho-soudnictvi-se-prohlubuje-nss-ma-pres-dva-pul-tisicenevyrizenych-veci/

[46] Ribeiro, M. T., Singh, S., Guestrin, C. "Why Should I Trust You?": Explaining the Predictions of Any Classifier. arXiv:1602.04938 [cs, stat]. 2016 [cit 27. 2. 2021]. http://arxiv.org/ abs/1602.04938

[47] School, S. L. Increasing Transparency in Algorithmic- Decision-Making with Explainable AI [online]. Stanford Law School [cit 27. 2. 2021]. https://law.stanford.edu/publications/increasing-transparency-in-algorithmic-decision-making-with-explainable-ai/ 
[48] Ulenaers, J. The Impact of Artificial Intelligence on the Right to a Fair Trial: Towards a Robot Judge? Asian Journal of Law \& Economics. 2020, č. 2, s. 1-38.

[49] Vincent, J. Twitter taught Microsoft's friendly AI chatbot to be a racist asshole in less than a day [online]. The Verge. 24. 3. 2016 [cit 6. 3. 2021]. https://www.theverge.com/ 2016/3/24/11297050/tay-microsoft-chatbot-racist

[50] Xue, Y., Van Hoeve, W.-J. Embedding Decision Diagrams into Generative Adversarial Networks. V: Rousseau, L.-M., Stergiou, K. (ed.). Integration of Constraint Programming, Artificial Intelligence, and Operations Research. 11494. Cham: Springer International Publishing, 2019, s. 616-632 [cit 9. 3. 2021]. Lecture Notes in Computer Science. http://link.springer.com/ 10.1007/978-3-030-19212-9_41

[51] Lauren, C. A Brief History of Automation [online]. Scadata. 30. 8. 2016 [cit 9. 3. 2021]. https://scadata.net/brief-history-automation/

[52] Federal Government's Directive on Automated Decision-Making: Considerations and Recommendations | McCarthy Tétrault [online]. [cit 3. 3. 2021]. https://www.mccarthy.ca/en/ insights/blogs/snipits/federal-governments-directive-automated-decision-making-considerations-and-recommendations

[53] OpenAI built a text generator so good, it's considered too dangerous to release [online]. TechCrunch [cit 28. 2. 2021]. https://social.techcrunch.com/2019/02/17/openai-text-generator-dangerous/

[54] Otto, P. Přetížené justici by ulevili dosluhující soudci [online]. E15.cz [cit 3. 12. 2020]. https://www.e15.cz/domaci/pretizene-justici-by-meli-ulevit-dosluhujici-soudci-1368700

[55] Sourdin, T. Judge V Robot? Artificial Intelligence and judicial decision-making. University of New South Wales Law Journal [online]. 2018, č. 41, 1114-1133. http://www.unswlawjournal.unsw.edu.au/wp-content/uploads/2018/12/Sourdin.pdf

[56] Wood, J., Allan, N. Sinking the Italian torpedo: the recast Brussels Regulation [online]. International Law Office. 10. 2. 2015 [cit 25. 11. 2020]. https://www.internationallawoffice.com/Newsletters/Litigation/European-Union/RPC/Sinking-the-Italian-torpedo-the-recast-Brussels-Regulation

\subsection{JUDIKATÚRA}

[57] Beaumartin proti Francúzsku, rozsudok Európskeho súdu pre l’udské práva, 24.11.1994 č. stažnosti 15287/89

[58] Camilleri proti Malte, rozsudok Európskeho súdu pre ludské práva, 16.03 .2000 č. stažnosti 51760/99

[59] Campbell a Fell proti Spojenému královstvu, rozsudok Európskeho súdu pre ludské práva, 28.06.1984 č. stažnosti 7819/77

[60] Doroshenko proti Ukrajine, rozsudok Európskeho súdu pre ludské práva, 26.05.2011 č. stažnosti 1328/04 
[61] Engel a d’alší proti Holandsku, rozsudok Európskeho súdu pre l’udské práva, 08.06.1976 č. stažnosti 5100/71

[62] Findlay proti Spojenému královstvu, rozsudok Európskeho súdu pre ludské práva, 25.02.1997 č. stažnosti 22107/93

[63] García Manibardo proti Španielsku, rozsudok Európskeho súdu pre ludské práva, 15.02.2000 č. stažnosti 38695/97

[64] Golder proti Spojenému královstvu, rozsudok Európskeho súdu pre ludské práva, 21.02.1975 č. stažnosti 4451/70

[65] H proti Francúzsku, rozsudok Európskeho súdu pre ludské práva, 24.10.1989 č. stažnosti $10073 / 82$

[66] Hauschildt proti Holandsku, rozsudok Európskeho súdu pre ludské práva, 24.05.1989 č. stažnosti 10486/83

[67] Kreuz proti Pol’sku, rozsudok Európskeho súdu pre l’udské práva, 19.06.2001 č. stažnosti 28249/95

[68] Nález Ústavného súdu zo dňa 30. marca 2010, sp. zn. Pl. ÚS 2/10

[69] Nález Ústavného súdu zo dňa 28. apríla 2005, sp. zn. Pl. ÚS 60/04

[70] Perez proti Francúzsku, rozsudok Európskeho súdu pre ludské práva, 12.02.2004 č. stažnosti 47287/99

[71] State v. Loomis [online]. [cit 1. 11. 2020]. https://harvardlawreview.org/2017/03/ state-v-loomis/

[72] Tserkva Sela Sosulivka proti Ukrajine, rozsudok Európskeho súdu pre ludské práva, 28.02.2008 č. stažnosti 37878/02

[73] Urbanek proti Rakúsku, rozsudok Európskeho súdu pre ludské práva, 09.12.2010 č. stažnosti 35123/05

\subsection{INTERNETOVÉ ZDROJE}

[74] High Level Expert Group on Artificial Inteligence. Brusel: Európska komisia. https://digital-strategy.ec.europa.eu/en/policies/expert-group-ai

[75] Open AI GPT Projects. https://openai.com/projects/

[76] WIPO Guide to the Uniform Domain Name Dispute Resolution Policy (UDRP). WIPO. https://www.wipo.int/amc/en/domains/guide/\#c

\subsection{PRÁVNE PREDPISY}

\subsubsection{ZÁKONY}

[77] Ústavní zákon č. 2/1993 Sb. ve znění ústavního zákona č. 162/1998 Sb., listina základních práv a svobod 
[78] Secretariat, T. B. of C. Directive on Automated Decision-Making [online] 5. 2. 2019 [cit 20. 3. 2020]. https://www.tbs-sct.gc.ca/pol/doc-eng.aspx?id $=32592$

[79] Zákon č. 1/1993 Sb., Ústava České republiky.

[80] Zákon č. 549/1991 Sb., zákon České národní rady o soudních poplatcích.

[81] Zákon č. 6/2020 Sb., o soudech a soudcích.

[82] Zákon č. 99/1963 Sb., občanský soudní řád.

\subsubsection{PRÁVNE PREDPISY EU}

[83] Nariadenie európskeho parlamentu a rady (EÚ) 2016/679 z 27. apríla 2016 o ochrane fyzických osôb pri spracúvaní osobných údajov a o volnom pohybe takýchto údajov, ktorým sa zrušuje smernica 95/46/ES (všeobecné nariadenie o ochrane údajov)

\subsubsection{MEDZINÁRODNÉ ZMLUVY}

[84] Európsky dohovor o ludských právach, v znení protokolov č. 11 a 14. Rada Európy.

\subsection{OSTATNÉ}

[85] Algorithms and human rights - Study on the human rights dimensions of automated data processing techniques and possible regulatory implications [online]. COE [cit 7. 3. 2021]. https://edoc.coe.int/en/internet/7589-algorithms-and-human-rights-study-on-the-human-rightsdimensions-of-automated-data-processing-techniques-and-possible-regulatory-implications.html

[86] Anonymous. Communication Artificial Intelligence for Europe [online]. Shaping Europe's digital future - European Commission. 25. 4. 2018 [cit 15. 5. 2020]. https://ec.europa.eu/digitalsingle-market/en/news/communication-artificial-intelligence-europe

[87] Anonymous. Quality of Public Administration - A Toolbox for Practitioners [online]. Shaping Europe's digital future - European Commission. 4. 5. 2015 [cit 17. 3. 2021]. https:// ec.europa.eu/digital-single-market/en/news/quality-public-administration-toolbox-practitioners

[88] Axess. Acquisition of Key Competences for Economic and Social Sustainability. Štrasburg: Erasmus + , 2017. http://www.axesslearning.eu/docs/AXESS-IO2-Snapshot-EU.docx

[89] CEPEJ. European ethical Charter on the use of Artificial Intelligence in judicial systems and their environment [online]. Council of Europe. [cit 23.12.2020]. https://rm.coe.int/ethicalcharter-en-for-publication-4-december-2018/16808f699c

[90] ECHR. Overview 1959 - 2018 [online]. Štrasburg: Council of Europe, 2019, 12 s. [cit. 02.03.2020]. https://www.echr.coe.int/Documents/Overview_19592018_ENG.pdf

[91] FIALOVÁ, Eva. Algoritmické rozhodování orgánů veřejné moci [online]. Brno, 2017 [cit. 2021-03-19]. Dostupné z: <https://is.muni.cz/th/xfw84/>. Rigorózní práce. Masarykova univerzita, Právnická fakulta. 
[92] High-level expert group on artificial intelligence. Ethics guidelines for trustworthy AI [online]. Európska komisia. 2019 [cit 01. 03. 2021]. https://ec.europa.eu/digital-single-market/en/news/ethics-guidelines-trustworthy-ai

[93] High-level expert group on artificial intelligence. Policy and investment recommendations for trustworthy AI [online]. Európska komisia. 2019 [cit 01. 03. 2021]. https:// ec.europa.eu/digital-single-market/en/news/policy-and-investment-recommendations-trustworthy-artificial-intelligence

[94] Mittelstadt, B., Russell, C., Wachter, S. Explaining Explanations in AI. Proceedings of the Conference on Fairness, Accountability, and Transparency. 2019, s. 279-288.

[95] MPO. Národní strategie umèlé inteligence v České republice. Czech republic The Country for the Future, 2019. https://www.vlada.cz/assets/evropske-zalezitosti/umela-inteligence/ NAIS_kveten_2019.pdf

[96] Northpointe. Practitioner's Guide to COMPAS Core. Michigan: Equivant, 2016, 65 s. https://assets.documentcloud.org/documents/2840784/Practitioner-s-Guide-to-COMPASCore.pdf

[97] The ECHR in facts \& figures 2019. ECHR. https://www.echr.coe.int/Documents/Facts_Figures_2019_ENG.pdf

[98] Violations by Article and by State 1959 - 2019. ECHR. https://www.echr.coe.int/Documents/Stats_viol tion_1959_2019_ENG.pdf

[99] WHITE PAPER On Artificial Intelligence - A European approach to excellence and trust. Brusel: Európska Komisia, 2020. https://ec.europa.eu/info/sites/info/files/commission-whitepaper-artificial-intelligence-feb2020_en.pdf

Toto dílo lze užít v souladu s licenčními podmínkami Creative Commons BY-SA 4.0 International (http://creativecommons.org/licenses/by-sa/4.0/legalcode). 